\author{
Universidade de São Paulo \\ Instituto de Biociências \\ Departamento de Fisiologia
}

Pedro Brisola Constantino

Ritmos de atividade coletiva e divisão temporal de tarefas em formigas saúvas

Activity rhythms and temporal division of labor in

leaf-cutting ants 
Pedro Brisola Constantino

\section{Ritmos de atividade coletiva e divisão de temporal de tarefas em formigas saúvas}

Dissertação apresentada ao Instituto de Biociências da Universidade de São Paulo, para a obtenção de Título de Mestre em Ciências, na área de Fisiologia Geral.

Orientador: Dr. André Frazão Helene

São Paulo 
Ficha catalográfica

Brisola Constantino, Pedro

Ritmos de atividade coletiva e divisão de temporal de tarefas em formigas saúvas/Pedro Brisola Constantino; orientador André Frazão Helene. -SãoPaulo, 2017

$103 \mathrm{f}$.

Dissertação (Mestrado) - Instituto de Biociências da Universidade de São Paulo, Departamento de Fisiologia.

1. Divisão de tarefas 2. Comportamento coletivo 3. Ritmos biológicos 4. Atta sexdens rubropilosa I. Frazão Helene, André, oriente. II. Título.

Comissão Julgadora

Orientador: Prof. Dr:

Assinatura:

Julgamento:

Prof(a). Dr(a):

Assinatura:

Julgamento:
Prof(a). Dr(a):

Assinatura:

Julgamento:

Prof(a). Dr(a):

Assinatura:

Julgamento: 


\section{Agradecimentos}

Ao meu orientador Prof. Dr. André Frazão Helene. Sua contribuição foi além da intelectual requerida para a conclusão desse trabalho. $\mathrm{O}$ aprendizado que eu obtive com a sua convivência transpõe o acadêmico e se consolida em várias lições nos aspectos sociais e cidadãos. Obrigado!

Aos meus amigos do Laboratório de Ciências da Cognição: Pedro, Wataru, Marcelo, Daniele, Nathalia, Vitor, Bruna, Mila, Yanina e Fernanda. O ambiente agradável cheio de companheirismo e permissivo a discussões de alto nível, tanto acadêmicas quanto de diversos outros assuntos se reflete nesse texto. Obrigado!

As profas. Gisele Akemi Oda e Verônica Valentinuzzi pelo auxilio na elaboração da metodologia e seus profundos conhecimentos em cronobiologia. Obrigado!

A minha mãe Suzeli Brisola Constantino, desde que eu era uma criança seus esforços em me criar sozinha e me educar proporcionaram as bases para que eu completasse esse trabalho e buscasse me aperfeiçoar e melhorar sempre. Saiba que seus esforços funcionaram tão bem que eu nunca mais vou parar de estudar. Muito Obrigado!

A minha família, Clarisse, Selma e Gabriel. Nossa convivência gerou um ambiente tão rico que definitivamente consolidou a pessoa que eu sou hoje e isso se reflete nesse texto. Obrigado!

A minha amada Amanda, uma veterinária brilhante que não gosta de formigas, mas me auxiliou e motivou durante todo o percurso do meu mestrado. Sem o seu apoio pessoal, emocional e intelectual esse trabalho não teria sido completado. O objetivo que traçamos para nossas vidas me compele e me motiva a dar o melhor de mim. Obrigado!

A família Nadalin, que me recebeu de braços abertos e me fez sentir parte da família. Em especial a Roseli Nadalin e a dona Isabel Nadalin pelos esforços semanais em pegar folhas para alimentar as formigas. Obrigado!

A CAPES agradeço o apoio financeiro imprescindível para a execução deste trabalho. $\mathrm{O}$ investimento em ciência e tecnologia é a porta para um futuro melhor. Obrigado! 


\section{Sumário}

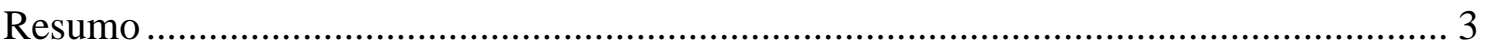

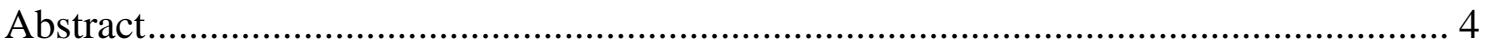

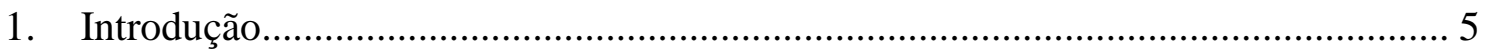

1.1. Aspectos relevantes à vida em sociedade ………………………………........ 6

1.2. A colônia como um superorganismo ………………................................... 10

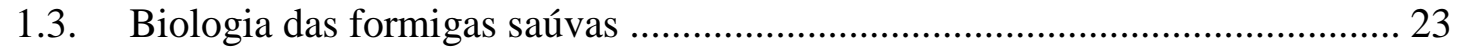

1.4. Aspectos cíclicos do ambiente e ritmicidade biológica ..................................... 29

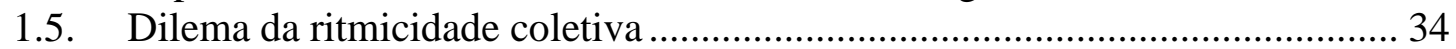

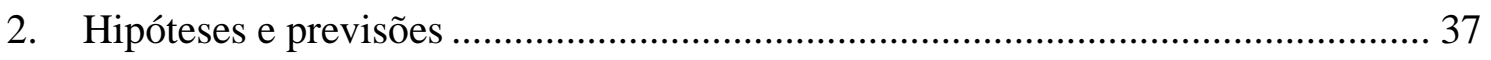

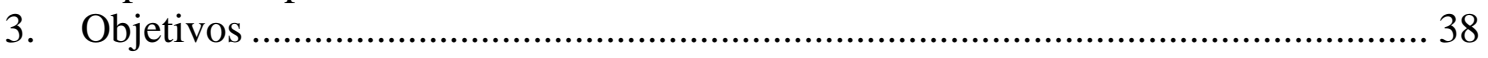

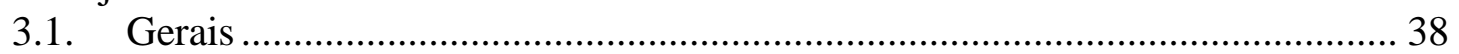

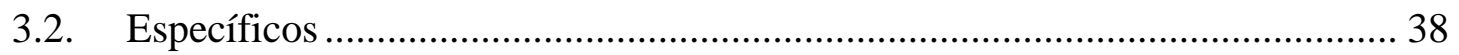

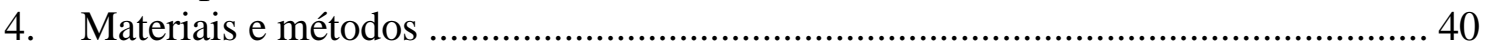

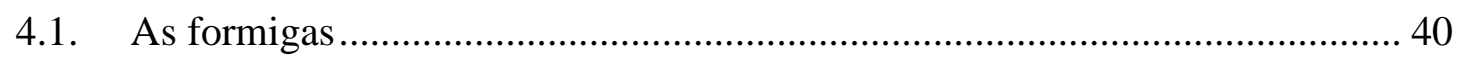

4.2. Manutenção dos animais............................................................................... 40

4.3. Arranjo experimental ............................................................................ 41

4.4. Protocolo de filmagem .......................................................................... 42

4.5. Protocolo de marcação e observação ............................................................ 43

4.6. Análise dos vídeos e contagem das formigas .................................................. 44

4.7. Análise de morfometria .............................................................................. 46

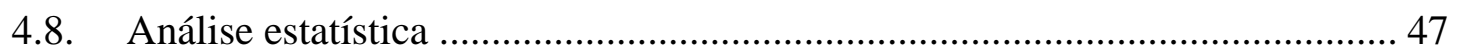

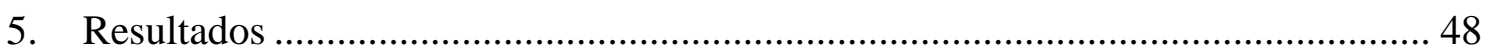

5.1. Análise do fluxo total de formigas na trilha ................................................ 48

5.2. Fluxo de formigas marcadas .................................................................. 50

5.3. Análise do transporte total de folhas............................................................... 55

5.4. Distribuição do transporte por formigas marcadas ............................................ 58

5.5. Correlação entre fluxo e transporte de folhas no claro e no escuro ................... 61

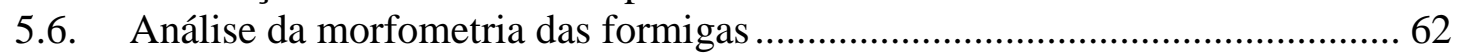

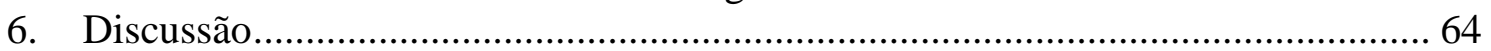

6.1. Distribuição temporal da atividade de formigas marcadas ................................. 67

6.2. Distribuição temporal do engajamento de formigas transportadoras ............... 71

6.3. Eficiência no transporte de folhas em diferentes fases ..................................... 73

6.4. Morfometria das formigas nas diferentes fases ............................................... 76

6.5. Formigas diferentes nas diferentes fases..................................................... 78

6.6. Organização temporal coletiva das formigas ..................................................... 81

6.7. Transposição do modelo de abelhas para formigas ………………………....... 82

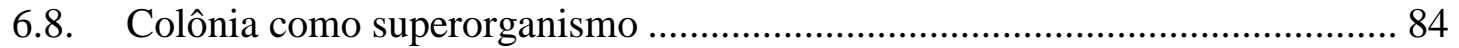

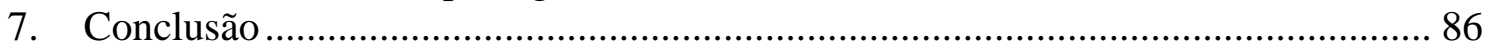

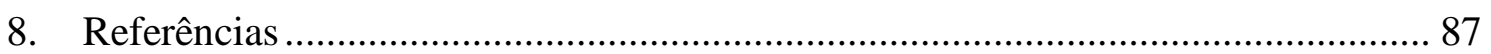

9. Material suplementar...................................................................................... 93 


\section{Resumo}

Os comportamentos coletivos observados em colônias de insetos eussociais muitas vezes podem ser explicados apenas pelo comportamento dos indivíduos que compõe a colônia. De fato, em muitas condições essa previsão se concretiza. Em outras condições o comportamento individual apenas não explica o comportamento coletivo. Atualmente sabe-se que vários fatores individuais, sociais e ambientais influenciam no comportamento que indivíduos, mesmo que de carga genética idêntica, irão apresentar. A divisão de tarefas observada nas colônias de insetos eussociais é um exemplo de como indivíduos semelhantes morfológica e geneticamente adotam comportamentos diferentes dependendo de inúmeros fatores inerentes à organização social.

A relação entre o comportamento dos indivíduos e as condições ambientais é intima, principalmente em relação às condições cíclicas. Inclusive existe um sistema fisiológico nos organismos que marca essa relação entre o comportamento e o tempo. Espera-se que cada indivíduo de uma colônia de insetos eussociais esteja munido desse aparato e que eles sejam semelhantes. Entretanto, em saúvas essa relação entre comportamento e ritmos ambientais se apresenta de maneira confusa. A colônia é noturna, com a maior atividade de suas operárias ocorrendo à noite, entretanto, vários indivíduos são vistos na fase de claro. Ou as forrageadoras são arrítmicas e podem forragear em qualquer fase do dia, ou as formigas se dividem em turno de trabalhos. A presente dissertação tem por objetivo descrever a existência de divisão temporal de tarefas em formigas saúvas.

Foram marcadas formigas em diferentes fases (claro e escuro) e turnos (horários específicos) e observou-se a distribuição do engajamento dessas formigas marcadas na tarefa de forrageamento ao longo de cinco dias nessas diferentes fases e turnos. Foi medido também o tamanho das formigas que foram observadas em claro e em escuro e a relação entre a atividade da colônia e a eficiência na coleta de alimento

Os resultados indicam que as formigas de fato dividem temporalmente a tarefa de forrageamento. Formigas de claro e formigas de escuro constituem grupos distintos, que forrageiam preferencialmente no mesmo horário. Além disso, essa divisão apresenta forte correlato com a morfologia, formigas de claro são maiores que formigas de escuro. Aparentemente essa divisão temporal de tarefa acarreta em implicações para a eficiência de forrageamento. No claro, apesar de o número de formigas observadas ser menor, a eficiência na coleta de alimentos é maior do que no escuro.

A relação observada entre a morfologia e a divisão temporal de tarefas pode ser explicada pela relação de resistência às condições ambientais. Formigas maiores tendem a ser mais resistentes a temperaturas mais elevadas. Como a incidência solar e a temperatura é maior no claro, faz sentido que exista essa divisão. Entretanto, resta saber quais mecanismos fisiológicos podem gerar indivíduos geneticamente semelhantes, mas que se relacionam de maneira diferente com as condições cíclicas do ambiente. 


\begin{abstract}
The collective behavior observed in social colonies can be explained by the behavior of its individuals, most of the time. Thus, it is expected that all workers should display the same behavior. Indeed, this prediction is fulfilled in many cases. However, many collective behaviors cannot be explained only by individual behaviors. Nowadays it is known that many individual, social and environmental conditions modulate the individual, and consequently, the collective behavior. The division of labor observed in social colonies is an example of different behaviors displayed by similar individuals reared in different conditions.

Behavior and environmental conditions are closely related, especially regarding the cyclic conditions. A physiological system whose function is modulate behavior concerning time was described. It is expected that each individual in a social colony bear this system and that they mark the same relationship. However, in leaf-cutting ants this system and the relationship between behavior and cyclic conditions appear to be more complex. The colony is nocturnal, because the main worker activity time happens at night; however, there is a significant amount of ants observed at day. Or the workers are arrhythmic and are able to forage at any time, or they divide the labor in work shifts. This dissertation aims to describe the process of temporal division of labor in leafcutting ants.

Workers of leaf-cutting ants were marked in different phases (dark and light) and shifts (specific time windows). This marked ants engagement in foraging was observed along five days on the same phases and shifts. Light and dark ants body size was measured as well as the correlation between colony activity and the food retrieval efficiency.

The results show that leaf-cutting ants indeed divide the labor in work shifts. Light ants and dark ants establish distinct groups. Additionally, there is difference in the ant body size of those groups: light ants are bigger than dark ants. It seems that the temporal division of labor implies in food retrieval efficiency differences. Although the fewer ants in the light phase, the food retrieval is bigger in light than in dark.

The relationship between morphology and temporal division of labor can be explained by the difference in thermal tolerance of different ant body size. Bigger ants can withstand higher temperature than smaller ants. It makes sense, day temperature is higher than night's. Hence, the process and physiological mechanisms that generate genetically similar workers whose relation to light-dark cycles is different remains to be studied.
\end{abstract}




\section{Introdução}

A percepção e integração de informações do ambiente e do meio interno do organismo, e os mecanismos regulatórios das condições internas é característica presente em todos os organismos vivos. De fato, essa premissa básica orientou as teorias, pesquisas e descobertas no campo da fisiologia, tanto animal quanto vegetal. $\mathrm{O}$ conceito de homeostase, como aplicado na fisiologia, só é possível porque os diversos sistemas fisiológicos possuem de alguma forma, mecanismos de integração de informações que permitem o controle das variáveis fisiológicas baseados nas mudanças constantes que ocorrem no meio externo e no próprio meio interno (SCHMIDTNIELSEN, 2000).

É possível aplicar este mesmo conceito a um sistema constituído de diversos organismos cujo funcionamento integrado e coeso é imprescindível para a manutenção e perpetuação do próprio sistema. Os insetos eussociais como abelhas e formigas constituem um exemplo notável desses sistemas. Vários indivíduos devem coordenar seus comportamentos de forma integrada de forma a viabilizar a colônia e permitir a sua sobrevivência e reprodução. Tal organização impõe vários desafios do ponto de vista funcional e organizacional. Cada indivíduo, além de buscar recursos para manter a sua própria condição individual em equilíbrio (i.e. homeostase), também deve buscar recursos para manter a sociedade à qual pertence. Note, portanto, que o estudo integrativo da organização espécies eussociais tende a ganhar utilizando-se de conceitos aplicados a organismos na fisiologia.

Não obstante, alguns autores consideraram colônias de insetos sociais como superorganismos. Isso porque, da mesma forma que um indivíduo possui linhagens de células germinativas e linhagens de células somáticas, uma colônia de insetos eussociais possui indivíduos reprodutivos e indivíduos não-reprodutivos (WILSON \& SOBER, 1989). Em alguns casos, como nas formigas cortadeiras, existe inclusive a especialização morfológica dos indivíduos não-reprodutivos às tarefas executadas por eles (WILSON, 1980), da mesma forma que existe especialização celular das células somáticas a diferentes funções nos diferentes tecidos do corpo. O conceito de superorganismo surgiu para tentar explicar a evolução dessa organização social tão particular e derivada. Entretanto, tais teorias caíram em desuso devido a novas 
descobertas no campo da evolução da eusocialidade (JOHNSON \& LINKSVAYER, 2010, NOWAK et al., 2010).

Ao longo das próximas páginas pretende-se discutir os mecanismos individuais de percepção do ambiente; os processos e fatores que influenciam na integração coletiva de informações; e os mecanismos e processos efetores dos comportamentos coletivos em organismos eussociais. Além disso, espera-se que o conceito de superorganismo apresentado acima seja expandido para além do contexto evolutivo em função das propriedades coletivas dessa organização social. Tal análise leva a conclusão que as colônias de insetos eussociais possuem a característica de perceber, integrar e responder a informações acerca do ambiente e do estado interno da colônia compatível com aquelas observadas em um organismo solitário. Tal capacidade transpassa os limites dos indivíduos que pertencem à colônia e torna-se uma propriedade do conjunto de animais que forma a sociedade. De maneira comparável à que acontece nos mais diversos organismos.

A presente dissertação intitulada "Ritmos de atividade coletiva e divisão temporal de tarefas em formigas saúvas" pretende se valer dessa abordagem comparativa. Dessa forma, se torna possível discutir novamente colônias a partir de uma abordagem de superorganismo, como forma de estudar os padrões comportamentais de uma organização social, utilizando-se das capacidades dos indivíduos componentes dessa organização de perceber, integrar e interagir com as condições ambientais externas cíclicas de luz e escuro.

\subsection{Aspectos relevantes à vida em sociedade}

\subsubsection{Evolução do altruísmo e eusocialidade}

Segundo Darwin, a vida em sociedade apresenta um desafio à teoria de seleção natural oferecida no texto "A origem das espécies". Em seu célebre livro ele escreveu:

"I... will confine myself to one special difficulty, which at first appeared to me insuperable, and actually fatal to my whole theory. I allude to the neuters or sterile females in insect communities: for these neuters often differ widely in instinct and in structure from both the male and fertile females, and yet from being sterile they cannot propagate their kind” (página 234) 
No trecho acima Darwin refere-se, ainda que de maneira geral, às características que vieram a definir a eusocialidade: (1) a divisão de tarefas reprodutivas, (2) sobreposição de gerações e (3) cuidado coletivo com a prole. Em formigas apenas a rainha tem a capacidade de se reproduzir; todas as outras operárias são estéreis (HOLLDOBLER \& WILSON, 1990). Portanto, em uma colônia é possível encontrar duas gerações de indivíduos (sobreposição de gerações). Para Darwin não seria possível à evolução de tal organização de acordo com o postulado em sua teoria da evolução por seleção natural, afinal, as operárias estéreis não teriam capacidade de reproduzir e perpetuar suas características e todos os comportamentos associados a ela. Muito pelo contrário, as operárias dedicam a sua vida a prover as irmãs (cuidado coletivo da prole), das quais, poucas virão a desenvolver características sexuais. Por outro lado, a rainha dá origem a operárias que não possuem as mesmas características que ela. Biologicamente, esse comportamento que sacrifica o fitness individual em detrimento do fitness de um aparentado é definido como comportamento altruísta. Vale ressaltar que a organização eussocial é o mais avançado tipo de integração social que as espécies podem apresentar com relação à coespecíficos (WILSON, 2000).

Por muito tempo compreender como se deu o processo de evolução de comportamentos altruístas foi um desafio para os biólogos. Mesmo após o neodarwinismo, com a incorporação das ideias de herança genética propostas por Mendel com a evolução por seleção natural e a propagação das características individuais, não havia uma explicação satisfatória para a evolução das sociedades complexas dos insetos. Ou seja, a questão sobre como um determinado indivíduo que sacrifica sua própria capacidade reprodutiva em prol do cuidado dispensado às suas irmãs permaneceu sem solução.

O advento das ideias de fitness inclusivo propostas por Hamilton em 1964 apresentou uma possível solução para esse desafio. De acordo com esse autor, o fitness de um indivíduo não é dado exclusivamente pelo sucesso reprodutivo do indivíduo em questão. O sucesso reprodutivo dos parentes desse indivíduo também deve ser considerado, pois esses parentes compartilham parte dos genes. Portanto, ao fitness individual deve ser somado ao fitness dos parentes, desde que corrigido pelo coeficiente de parentesco. Assim, indivíduos aparentados compartilham genes e, portanto, existe a possibilidade de um gene que confere a característica altruísta seja selecionado caso ele beneficie parentes, conforme postulado em sua equação: 
r.b $>$ c

Onde, em termos de fitness, 'b' é o beneficio obtido por um indivíduo com um ato altruísta, 'c' é o custo e ' $r$ ' é o coeficiente de parentesco.

Esse conceito parece particularmente interessante quando aplicado a insetos eussociais himenópteros, como as formigas observadas por Darwin, cujo modelo genético de determinação sexual é haplodiploide. Nesse caso, fêmeas são diploides (2n) e machos são haploides (n). Por consequência, fêmeas irmãs neste sistema possuem um coeficiente de parentesco ' $r$ ' de aproximadamente 0.75 , já que operárias recebem apenas um cromossomo do pai (figura 1). Enquanto organismos que possuem sistema de determinação sexual diploide, como a maioria dos mamíferos, irmãos apresentam $r$ de 0.50, já que elas podem receber um dos dois cromossomos parentais (ABBOT et al., 2005).

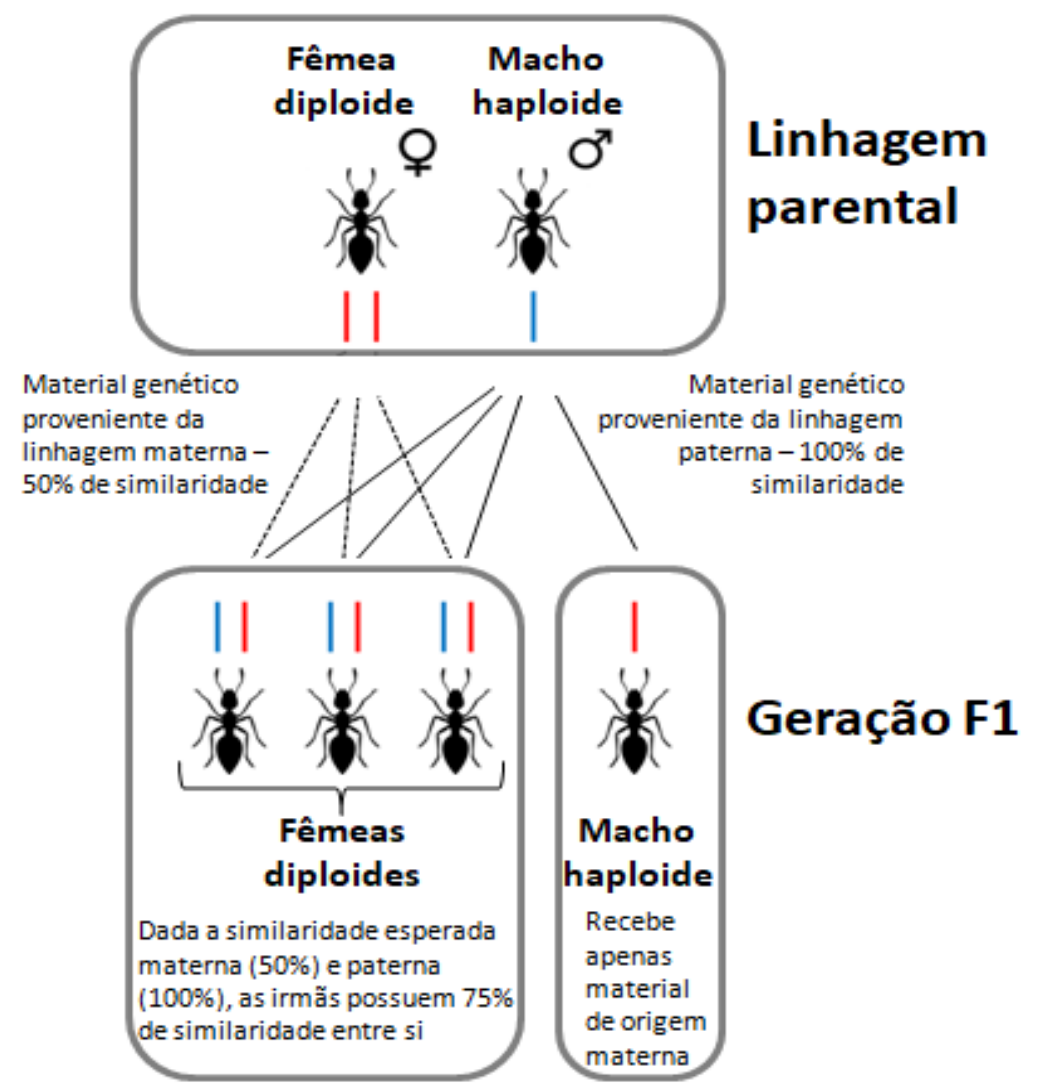

Figura 1. Esquema da diferenciação sexual por haplodiploidismo presente nos himenópteros. 
Assim, com base na equação proposta por Hamilton, é possível defender que o benefício em realizar atos altruísticos possa existir em indivíduos que pertençam ao sistema haplodiploide. Dessa forma, acredita-se que foi possível a evolução de uma sociedade onde alguns indivíduos sacrificam seu fitness individual em prol de seus parentes, de maneira a privilegiar a propagação do gene que confere o altruísmo.

Apesar de essa explicação ter sido aceita por muito tempo, atualmente existe um debate dentre os estudiosos de evolução de altruísmo acerca da relação entre a haplodiploidia presente nos himenópteros sociais e as ideias propostas por Hamilton para explicar o comportamento altruísta (NOWAK, et al., 2010). Diversos estudos mostram que não são apenas os himenópteros que apresentam organização eusocial. Cupins, crustáceos do gênero Synalpheus (DUFFY et al., 2000), e roedores Heterochephalus glaber (INGRAM et al., 2015) e Fukomis damarensis (YOUNG et al., 2015), também apresentam organização eussocial, e esses organismos possuem determinação sexual diploide. Por outro lado, existem algumas abelhas e vespas que são haplodiploides, mas que não são eussociais.

Tais evidências levaram alguns pesquisadores a propor que a haplodiploidia não seria o mecanismo por trás da evolução da eusssocialidade, uma vez que organismos diploides, apesar de mais raros, também se organizam de forma eussocial. Dessa forma, modelos matemáticos que demonstram como a eusocialidade poderia evoluir apenas por seleção natural, sem incluir o fitness inclusivo de Hamilton foram desenvolvidos, por exemplo: os processos de seleção de grupo; reciprocidade direta, indireta e em rede (HOLLDOBLER \& WILSON, 2005; NOWAK et. al, 2010). De qualquer forma, a origem da organização eussocial e suas implicações para os modelos de evolução e genética de população ainda estão em debate.

Independente dos aspectos que subjazem à evolução dessa organização, a eussocialidade surgiu diversas vezes e em diversos táxons ao longo da evolução. Como já mencionado, entre os mamíferos, duas espécies de roedores Heterochephalus glaber e Fukomis damarensis apresentam eussocialidade. Entre os artrópodes eussociais existe o gênero de crustáceos Synalpheus; nos insetos existem os cupins, que pertencem à família Blattodea e a maioria das espécies de himenópteros (vespas e abelhas). Mesmo entre os himenópteros é discutido que a eusocialidade teve múltiplas origens nas diversas famílias que compõe a ordem (REHAN \& TOTH, 2015). É importante ressaltar que todas as espécies de formigas apresentam eusocialidade. 


\subsubsection{Ecologia das espécies eussociais}

É inegável o sucesso evolutivo que a organização eussocial trouxe para as espécies de himenópteros. São mais de 150.000 espécies em todos os ecossistemas terrestres, exceto os polos. Himenópteros sociais ocupam todos os nichos ecológicos, desde predadores, como boa parte das vespas; até polinizadores altamente especializados, como as abelhas; e simbiontes, como as formigas cortadeiras (BUZZI, 2010). Compreender sua estrutura social de organização permite tratar de sua relação com o ambiente e como estas serão influídas por possíveis alterações deste. Isso é importante em um momento no qual a população das abelhas está em declínio acentuado devido a causas ainda não esclarecidas. Discute-se, entretanto, que as mudanças climáticas globais podem ser uma das causas preponderantes deste declínio Vale ressaltar que a perda destas populações pode ter graves consequências. Somente a redução da população de abelhas traz consigo um alto impacto para as atividades agrárias, já que 1/4 das espécies vegetais cultivadas para consumo humano dependem da polinização por abelhas (BUCANDRITSOS et al., 2010; ELLIS et al., 2010; CAMERON et al., 2011).

Vale ressaltar que as interações ecológicas que uma determinada espécie eussocial mantém com as espécies ao redor podem influenciar nos mecanismos de manutenção da organização social. Alguns animais são capazes de explorar 'brechas' no sistema social desses animais em beneficio próprio. É o exemplo de mariposas Eublemma albifascia: lagartas dessa espécie exploram a comunicação olfativa de formigas e são levadas para dentro das colônias de formigas Oecophylla longinoda; posteriormente induzem operárias a alimentá-las em detrimento da própria rainha da colônia; eventualmente a rainha morre e a lagarta continua seu desenvolvimento explorando o comportamento altruístico das operárias (DEJEAN et al., 2016).

\subsection{A colônia como um superorganismo}

\subsubsection{Percepção do ambiente e aquisição de informações}

A aquisição de informações acerca das condições dos companheiros de sociedade e do ambiente ao redor é extremamente importante para os indivíduos que se organizam em sociedades. Os insetos eussociais adquirem essas informações através 
dos seus sistemas sensoriais. Diversas modalidades de sistema sensorial são encontradas nos insetos eussociais. Visão, audição, olfato e até mesmo magnetorrecepção (BANKS \& SRYGLEY, 2015) são modalidades sensoriais que já foram descritas (NATION, 2008). Tais modalidades estão presentes em todos os indivíduos da colônia e espera-se que cada um deles seja capaz de perceber o estado do ambiente ao redor e dos companheiros de modo a compor de maneira sinérgica o todo coletivo organizacional.

Assim como a maioria dos animais, os insetos eussociais estão munidos de estruturas especializadas na captação de estímulos ambientais e na transformação desses estímulos em informações passíveis de serem processadas. As estruturas mais conspícuas e que foram extensamente estudadas são os olhos e as antenas, responsáveis pela captação de estímulos luminosos e químicos respectivamente (CHAPMAN, 1998).

Os olhos compostos dos insetos eussociais, dependendo da espécie, são capazes de captar com uma resolução considerável os estímulos visuais. Já foi descrito que tanto abelhas quanto formigas conseguem se orientar no espaço apenas com pistas visuais (VILELA et al., 1987), foi descrito também que abelhas são capazes de reconhecer e diferenciar padrões gráficos (GIURFA, 2013). Além disso, as faixas do espectro eletromagnético que abelhas e formigas conseguem captar foram identificadas e, inclusive, foi descrito que a maioria dos insetos eussociais é capaz de distinguir luz polarizada e captar ondas ultravioletas (WEHNER, 1976). Tudo isso indica a importância dessa modalidade sensorial para a interação dos indivíduos com o seu ambiente.

Estudos recentes indicam que a percepção olfativa é tão importante para a organização social de formigas, que, quando essa modalidade sensorial é completamente removida, indivíduos sem olfato não são capazes de se relacionar com suas companheiras e apresentam déficit de desenvolvimento cerebral. Tais conclusões foram retiradas da observação do comportamento de formigas geneticamente modificadas que não eram capazes de transduzir os estímulos olfativos devido ao knock-out de uma proteína envolvida na formação dos receptores olfativos. Essas formigas geneticamente modificadas apresentaram comportamentos aberrantes como: não agregação com suas companheiras, agressividade excessiva e perda da capacidade de se orientar por marcações feromonais. Além das alterações comportamentais, essas formigas apresentaram subdesenvolvimento dos lobos antenais, a estrutura cerebral 
responsável pelo processamento de informações olfativas (TRIBLE et al., 2017; YAN et al., 2017).

A capacidade olfativa dos insetos eussocias acerca de aspectos ambientais estão bem descritas. A principal estrutura de captação de estímulos químicos são as antenas, nelas existem células especializadas na captação de diversas substâncias químicas volatilizadas no ar. Tanto abelhas quanto formigas são capazes de perceber a presença de certos compostos químicos no ar e responder de acordo com o estímulo. Abelhas, por exemplo, são capazes de discriminar qual o melhor recurso floral no qual forragear através da concentração de uma determinada substância volátil que o pólen de uma flor exala (DOBSON et. al, 1999). Formigas Azteca sp., por outro lado, conseguem captar substâncias voláteis exaladas por folhas danificadas de Cecropia sp., e organizar uma resposta de defesa à sua planta anfitriã (ANURAG et al., 1999).

Não apenas aspectos químicos estão envolvidos na ação das antenas. Em uma colônia, mais do que simplesmente captar informações para uso individual, cada membro da sociedade comunica-se de forma ativa com outros. Ou seja, através de determinados comportamentos os indivíduos são capazes de sinalizar o seu próprio estado e o estado do ambiente no qual ele se encontra. Como é o caso do comportamento de antenação em formigas. Formigas da espécie Atta colombica são capazes de comunicar através da taxa de contato das antenas o nível de agrupamento de formigas em uma determinada fonte de alimento. Foi identificado que existe uma correlação positiva entre o número de contatos de antenas, entre uma formiga que se direciona para a fonte de alimento e outra retorna, e o número de formigas que já está em uma determinada fonte de alimento (DUSSUTOUR et al., 2007). Dessa forma, as formigas se comunicam ativamente entre si para indicar o estado do ambiente no qual elas se encontram.

Vale ressaltar que cada indivíduo recebe inúmeros estímulos, tanto ambientais quanto sociais. É particularmente interessante notar que o comportamento adotado após essa estimulação também é individual. Ou seja, as características sensoriais citadas acima e os comportamentos adotados frente aos estímulos recebidos dizem respeito a cada indivíduo da colônia. Entretanto, quando vários indivíduos respondem coletivamente aos diversos estímulos presentes em um determinado ambiente, comportamentos mais complexos emergem. Exemplos, processos e mecanismos sobre esse fenômeno serão abordados em seguida. 


\subsubsection{Integração de informações}

Do ponto de vista do indivíduo, como abordado anteriormente, cada um deles está munido de sistema sensorial afinado para diferentes modalidades de estímulo (principalmente olfativo e visual no caso dos insetos eussociais); de um sistema nervoso, onde as diversas informações advindas dos sistemas sensoriais são integradas; e de múltiplos efetores tanto musculares como endócrinos e exócrinos (glândulas de feromônio) (CHAPMAN, 1998). De maneira simplificada, é possível afirmar que o comportamento executado por um determinado indivíduo é o resultado final da integração das informações recebidas pelo sistema sensorial em uma complexa rede de neurônios que, em ultima instância, controla os efetores gerando um comportamento que é observável.

Quando vários indivíduos convivem e interagem entre si é possível realizar a análise do processo de integração de informações em outro nível hierárquico, além do individual. Os diversos comportamentos coletivos das sociedades de insetos, por exemplo, dependem da integração das informações que cada indivíduo recebe e transmite. Ou seja, em sociedades existe a integração das informações ao nível social a fim de possibilitar o comportamento coletivo coordenado.

Para que o compartilhamento de informações ocorra com sucesso é necessário que a informação seja transmitida entre os indivíduos. Ao contrário de um organismo individualizado, cuja coordenação das atividades de suas diversas partes funcionais se dá por meio de um sistema fechado, onde todas essas partes encontram-se conectadas espacialmente em um meio interno e controlado; a comunicação entre os indivíduos de uma sociedade precisa transpor uma barreira espacial, já que nem sempre todos os indivíduos que deverão agir estão em contato um com os outros. Portanto, a integração das informações depende da capacidade de comunicação que os indivíduos possuem.

Um exemplo notável de como indivíduos pertencentes a uma sociedade integram informações coletivas vêm dos estudos clássicos de Karl Von Frisch (1957) em comportamento de abelhas. Em seus estudos ele descreveu que uma abelha forrageadora que obteve sucesso em encontrar uma fonte de alimento adequada retornava ao ninho e comunicava a outras abelhas a localização do referido alimento através de uma dança, que ficou conhecida como "waggle dance". Neste comportamento a abelha que encontrou a fonte de alimento retorna ao ninho e exibe um 
padrão de movimentos estereotipados em forma de um '8'. Como é possível observar na figura $\mathrm{x}$ essa série de movimentos codifica uma mensagem que indica a direção e distância da fonte de alimento à colmeia. As outras operárias que recebem essa informação podem seguir a indicação da companheira e, dessa forma, o recurso alimentar é garantido com sucesso para todas (FRISCH \& JANDER, 1957).

Note que a "waggle dance" é um exemplo de como informações são compartilhadas entre indivíduos de uma sociedade e de como essa informação é integrada para gerar um comportamento coletivo que permite a manutenção da organização social. Vale ressaltar que a análise desse comportamento pode ser feita em dois níveis hierárquicos: (1) individual, que depende das capacidades da operária de navegar pelo espaço, localizar uma fonte de alimento, analisá-la do ponto de vista de qualidade e distância, discerni-la como uma fonte de alimento adequada e tomar a decisão de transmitir essas informações para as companheiras; e (2) coletivo, que depende da tomada de decisão coletiva das operárias em seguir uma informação nova que pode levar a uma fonte de alimento. Neste caso, a barreira da comunicação entre as partes da sociedade é vencida através da comunicação visual. Não obstante, as abelhas possuem o sistema visual bem desenvolvido uma vez que se utilizam deste sistema para a localização dos alimentos. Neste contexto, é possível que a comunicação visual através da dança tenha surgido explorando essa característica já existente nas abelhas.

Já as formigas utilizam outro efetor como meio de se comunicar e integrar informações. Todas as operárias de formigas não possuem asas e, portanto, deslocam-se pelo substrato. É difícil estabelecer uma relação de causa e consequência entre o hábito de vida e a evolução de características morfofisiológicas, mas durante o processo evolutivo deste grupo o principal sistema sensorial desenvolvido foi o olfativo. Neste contexto, as formigas utilizam-se de feromônios como forma de se comunicar e de integrar informações. Uma peculiaridade da comunicação por feromônios é o tempo pelo qual ele permanece no ambiente continuamente informando a mesma mensagem (BOSSERT \& WILSON, 1963). Já é bem descrito o papel que a comunicação por feromônios tem para a exploração de recursos alimentares por formigas de diversas espécies. Uma vez que uma determinada formiga encontre uma fonte de alimento e retorne para o ninho depositando feromônio no caminho, outras formigas são impelidas a seguir o caminho marcado dada a atratividade que o feromônio possui (WILSON, 1962a). Wilson (1962b) descreveu a alteração de comportamento que o feromônio 
depositado em alguma superfície causa para as formigas. Ao experimentalmente depositar concentrações diferentes de feromônios em uma superfície ele observou que diversas formigas da espécie Solenopsis invicta eram atraídas para o local onde o feromônio foi depositado (WILSON, 1962c). A esse fenômeno ele deu o nome de recrutamento em massa. Mais ainda, ele descreveu que o número de formigas atraídas para aquele ponto decaía com tempo, indicando que a mensagem codificada pelo feromônio permanecia no ambiente por certo período de tempo e eventualmente desaparecia. Estudos posteriores demonstraram algumas singularidades que essa forma de comunicação em formigas tem para a organização coletiva dos indivíduos. Goss e colaboradores (1989) demonstraram que por essa característica de permanecer no ambiente por certo tempo (com certa taxa de decaimento) e pelo fato de formigas seguirem o caminho com maior concentração de feromônios, formigas Iridomyrmex humilis, quando obrigadas a escolher entre dois caminhos de tamanhos diferentes, eram capazes de encontrar o menor deles entre a colônia e a fonte de alimento. Note que no exemplo das formigas as informações contidas na comunicação feromonal são integradas na forma de atratividade à trilha pela maior concentração de feromônios e pela decisão coletiva de seguir o caminho que possuí maior concentração de feromônios.

Tanto no exemplo da dança das abelhas quanto no exemplo do recrutamento em massa das formigas a tarefa de forrageamento é desempenhada com sucesso apenas quando as informações sobre a fonte de alimento são compartilhadas e processadas coletivamente pelos vários indivíduos da colônia. Vale notar que as estratégias de comunicação evoluíram de forma colateral aos hábitos de vida dos animais.

Uma característica notável dos sistemas sociais biológicos, e que também influencia como a informação é integrada coletivamente, é o tamanho que as colônias podem alcançar. Colônias de insetos eussociais podem variar de algumas dezenas de indivíduos, como em algumas vespas; a dezenas de milhões, como em formigas cortadeiras. Tal diferença de tamanho incorre em diferenças na velocidade de transferência e no alcance de uma informação que eventualmente chegue ao ninho (PACALA et al., 1996). Portanto, o processamento coletivo de uma determinada informação depende, não somente da modalidade pela qual ela é transmitida (visual ou feromonal), mas também pelo número de indivíduos que ela alcança. 
Um exemplo de como o tamanho do grupo influencia na integração da informação pode ser encontrado nos modelos matemáticos baseados em formigas propostos por Pacala e colaboradores em 1996. Tais modelos indicam que quanto maior o grupo, maior será a taxa de contato entre os indivíduos e, portanto, maior será a transmissão de informação entre eles. Consequentemente, quando estes modelos foram confrontados com situações de mudanças no ambiente, os grupos maiores apresentaram maior sucesso em se ajustar ao novo ambiente (NAUG, 2009). Tais modelos matemáticos também foram aplicados em sistemas biológicos e os resultados foram similares aos previstos.

Indivíduos vivendo em grupo se locomovem em relação uns aos outros. Isso significa que a região espacial ocupada por cada indivíduo varia ao longo do tempo. Portanto, uma vez que a informação a ser processada coletivamente depende da transmissão por entre os indivíduos do grupo, é razoável afirmar que a organização espacial de cada membro influencia em como a informação será processada coletivamente. De fato, é possível encontrar na literatura exemplos de como os padrões espaciais afetam o comportamento coletivo observado em vários sistemas sociais.

O rastreamento de todos os indivíduos de uma colônia de Camponotus fellah mostra que cada membro da sociedade ocupa uma região espacial especifica da colônia. Ou seja, cada indivíduo permanece constantemente percorrendo o mesmo espaço. Por consequência, os indivíduos não tem acesso a todas as regiões da colônia e, portanto, não são apresentados aos mesmos estímulos com a mesma intensidade. Uma característica coletiva que surge dessa organização espacial é que os indivíduos dessas colônias engajam-se em tarefas diferentes dependendo da localização em que eles se encontram. Formigas que eventualmente encontrem uma fonte de alimento apresentam comportamento de forrageio; já formigas que se encontram perto de ovos e larvas, assumem comportamentos de cuidado parental. É possível observar que, nesse caso, o comportamento adotado depende dos estímulos ambientais presentes naquela localização. As formigas possuem uma rede limitada de interações, uma vez que elas tendem a ocupar o mesmo espaço, suas companheiras vizinhas também tenderão a serem as mesmas. No contexto da transmissão e integração de informações, isso significa que a informação só pode ser transmitida por entre os indivíduos que mantém interações constantes entre si (MERSCH et al., 2013). 
Dessa forma é possível argumentar que o sucesso de uma organização social depende da integração de informações que chegam a essa sociedade e da resposta adequada a essas informações. Entretanto, a forma como essas informações podem chegar aos indivíduos e serem integradas por eles dependem da biologia das espécies sociais (modalidades de comunicação social); do tamanho dos grupos que elas formam; e da organização espaço-temporal que os indivíduos apresentam dentro da colônia. Porém, resta uma questão: uma vez que as informações chegam aos indivíduos e são integradas, como os membros de uma colônia são capazes de organizar suas ações? É provável que o entendimento de tal organização se de exatamente pela coordenação entre os aspectos individuais e coletivos.

\subsubsection{Organização dos indivíduos na resposta coletiva}

Perceba que no exemplo das dança das abelhas, citado anteriormente, a informação é trazida por uma única abelha batedora. Entretanto, como no exemplo das formigas que encontram o caminho mais curto (ver adiante detalhes), as informações chegam de diversas fontes e indivíduos simultaneamente. Frente a todas as informações recebidas os indivíduos devem tomar uma decisão sobre qual comportamento adotar. No caso das abelhas, elas devem decidir qual fonte de alimento visitar. No caso das formigas, qual caminho seguir.

Mais do que uma simples tomada de decisão coletiva em função de uma única tarefa (i.e. escolher onde forragear), os vários indivíduos de uma sociedade também precisam coordenar a execução simultânea de diversas tarefas de manutenção da colônia. Ou seja, uma colônia, para prosperar, precisa que várias tarefas sejam executadas ao mesmo tempo. Portanto, após a integração das informações acerca das diferentes tarefas, outro desafio da vida em sociedade precisa ser vencido: Como coordenar a atividade de vários indivíduos que são responsáveis pelo desempenho de várias tarefas?

Talvez a característica mais fascinante dos comportamentos sociais que surgem em colônias de insetos eussociais seja o polietismo entre as operárias. Ou seja, os diferentes comportamentos que as operárias assumem para cumprir as diferentes tarefas de manutenção da colônia. Independente da espécie estudada é possível observar que 
indivíduos geneticamente idênticos dentro de uma mesma colônia (já que as operárias são irmãs) desempenham tarefas diferentes dependendo dos estímulos aos quais eles são apresentados. Mais especificamente, a divisão de tarefas pode ser caracterizada pela especialização de um grupo de indivíduos em um subconjunto da totalidade de tarefas que são executadas em uma colônia (WILSON, 2000; JEANNE, 2016). Como no exemplo citado anteriormente das formigas Camponotus felah, que desempenham as tarefas de cuidado parental, ou forrageamento, ou gerenciamento do lixo, dependendo da posição espacial que elas ocupam na colônia. Vale ressaltar que essas três tarefas estão sendo desempenhadas simultaneamente por diferentes indivíduos; e que a correta execução desses comportamentos propiciam o ambiente adequado para 0 desenvolvimento da colônia. Portanto, é seguro afirmar que os indivíduos de uma colônia são capazes de realizar todas as tarefas de manutenção do ninho porque eles são capazes de dividir as tarefas entre si.

Compreender os mecanismos e processos que levam os indivíduos de uma sociedade a executar coordenadamente o conjunto de comportamentos de manutenção da colônia é imprescindível para o entendimento do funcionamento dessa organização que aparentemente obteve tanto sucesso na história evolutiva. Ou seja, compreender as regras que determinam a divisão de tarefas entre os indivíduos é um campo que merece ser estudado.

Isso é especialmente interessante em um sistema que possuí um sistema de controle disperso. Voltando ao exemplo das formigas que encontram o caminho mais curto (GOSS et al., 1989), é interessante observar que não existe um comando central que identificou o caminho mais curto e obrigou as formigas a seguirem ele. Nos insetos eussociais não existe uma cadeia hierárquica onde uma determinada operária concentra o poder de decisão e comanda todas as outras. Cada operária possui autonomia para tomar a sua própria decisão frente aos estímulos presentes. A divisão de tarefa surge, portanto, da somatória da tomada de decisão de cada indivíduo.

O modelo de auto-organização visa compreender como ocorre esse processo de formação de padrões complexos por estruturas menores e mais simples. As premissas desse modelo são de que o padrão complexo surge apenas pela interação das numerosas partes componentes do nível inferior sem a pressão de um agente externo. Assim, é possível encontrar exemplos de organização biológica que podem ser explicados pelo modelo de auto-organização em diversos sistemas. Desde os padrões de organização de 
Dyctiostelium discoideum, uma ameba do filo Mycetozoa; a organização de um cardume de peixes; ao cintilar sincronizado de vagalumes; à secreção rítmica de melatonina nos pinealócitos da glândula pineal de mamíferos (CAMAZINE, 2003).

No modelo de auto-organização é preciso compreender quais são as unidades do sistema e quais as regras que ditam como essas unidades se comportam. Em formigas, compreender que as unidades são as operárias é relativamente simples; entretanto compreender quais são as regras que definem o comportamento individual de cada operária é mais complicado. Entretanto alguns exemplos já foram bem descritos e parecem respeitar bem o modelo da auto-organização.

No exemplo citado anteriormente de Goss (1989), a regra que aparentemente define a seleção do caminho mais curto é bem simples: formigas são atraídas para a maior concentração de feromônio. Levando em conta essa regra e a própria característica do feromônio de se volatilizar e perder concentração ao longo do tempo (WILSON, 1962a), chega-se a um modelo de alça de retro-alimentação positiva no qual mais formigas passam pelo menor caminho e, por consequência, depositam mais feromônio, que por sua vez, atraem mais formigas; levando a escolha coletiva do caminho mais curto. Uma ressalva deve ser feita neste sistema: nem todas as formigas da colônia recebem o estímulo feromonal, consequentemente, essas formigas que não recebem o estímulo engajam-se em outras tarefas. Portanto, formigas que recebem o estímulo engajam-se no forrageamento e formigas que não recebem esse estímulo realizam outra tarefa.

Outro exemplo notável de como a auto-organização pode ser um modelo para explicar os complexos comportamentos coletivos que emergem da interação dos indivíduos é a arquitetura dos favos construídos pelas abelhas melíferas. Após a construção dos favos as abelhas preenchem as celas com ovos, pólen ou mel. O armazenamento de cada um desses componentes está associado à manutenção de diferentes funções dentro do ninho (deposição de ovos está ligado a reprodução e pólen e mel ao suprimento energético). As abelhas seguem um padrão concêntrico de preenchimento dessas celas. Os ovos são depositados na região central, seguido por um anel de pólen e uma região periférica de mel. Por certo tempo, pensou-se que as abelhas seguiam esse padrão devido a algum tipo de arquitetura pré-planejada codificada de alguma maneira por componentes genéticos. Entretanto, Camazine (1991), demonstrou empiricamente e com modelos computacionais que esse padrão emergia 
espontaneamente através da interação das abelhas entre si e das constantes retiradas e deposições de ovos, pólen e mel. Aparentemente as regras que regem esse sistema coletivo são relativamente simples: (1) a rainha deposita ovos em qualquer cela vazia; (2) celas com mel e pólen são esvaziadas mais rápido que celas de criação, por causa da diferença do tempo de maturação de um ovo e de uso de mel e pólen pelas operárias; (3) celas de mel e pólen mais próximas à cela de criação são esvaziadas preferencialmente (CAMAZINE, 1991). Com essas 3 regras o padrão concêntrico de distribuição de ovos, pólen e mel é alcançado sem a necessidade de que abelhas tenham um projeto arquitetônico de suas colmeias.

A divisão de tarefas pode certamente ser explicada pelos modelos de autoorganização, entretanto, este não é o único modelo que pode explicar como insetos eussociais dividem as diferentes tarefas de manutenção do ninho entre si. Outro modelo proposto e estudado empiricamente diz respeito aos limiares de resposta a um estímulo. Esse modelo postula que os diferentes indivíduos de uma colônia possuem limiares diferentes aos diferentes estímulos que são apresentados as colônias. Portanto, esses diferentes indivíduos vão responder diferentemente aos estímulos, gerando padrões no qual alguns organismos desempenham algumas tarefas, enquanto outros desempenham outras (DETRAIN \& PASTEELS, 1991).

Ainda não está bem estabelecido o que pode causar essa diferença nos limiares dos indivíduos. Entretanto, é possível argumentar que essas diferenças podem ser tanto geneticamente codificadas e, portanto, seriam fixas, quanto podem ser responsivas ao ambiente ou parte de aquisição de memória e, portanto, seriam variáveis. Exemplos de ambos os cenários já foram encontrados em sistemas biológicos sociais reais (BONABEAU et al., 1996; JANDT \& DORNHAUS, 2014).

Formigas operárias da espécie Pheidole pubiventris apresentam diferenças morfológicas e podem ser agrupadas em dois grandes grupos: as maiores e as menores. Wilson (1984) identificou que existe diferença nas tarefas executadas por essas duas castas. As maiores são responsáveis pela coleta de alimento, enquanto as menores são responsáveis pelo cuidado com a prole. Quando todas as operárias menores são removidas e, portanto, o cuidado com a prole se torna deficitário, as maiores passam a exercer essa tarefa. Bonabeau, et al., (1996) argumenta que além das diferenças morfológicas, existe diferença no limiar de resposta aos estímulos relacionados com o cuidado com a prole. Nesse contexto, as formigas menores possuem menor limiar de 
resposta ao cuidado com a prole e, com estímulos menores, a resposta comportamental já é ativada. Já as formigas maiores possuem limiar maior, portanto, elas não se engajam nessa tarefa. Entretanto, quando as menores são removidas o estímulo para o cuidado com a prole começa a aumentar (pela falta de cuidado) e atinge o valor do limiar das maiores, que passam a se engajar nessa tarefa. Esse contexto apresentado acima foi modelado e apresentou resultados semelhantes ao observado no sistema biológico real. Nesse contexto, os limiares seriam fixos e codificados da mesma forma que a diferença morfológica entre as castas.

Nem sempre os modelos de limiar precisam ser fixos e associados a diferenças morfológicas para que a divisão de tarefas surja no contexto social. Modelos matemáticos de auto-reforço indicam que um grupo de indivíduos que inicialmente exibe o mesmo conjunto de comportamentos, invariavelmente se subdivide em subgrupos com um conjunto de comportamentos mais restrito (THERAULAZ et al., 1998). Tais modelos, quando confrontados com sistemas biológicos obtém corroboração. Esse é o caso das abelhas melíferas, cuja morfologia das operárias é idêntica, em situação pré e pós-déficit de alimentação. Em um trabalho Fewell \& Page Jr. (2000) criaram abelhas em duas situações diferentes: (1) com ausência de mel e (2) com ausência de pólen. Os autores observaram que, quando oferecido os dois tipos de alimento, as abelhas forrageavam preferencialmente aqueles que estavam em falta. Porém, o dado mais relevante para o modelo de auto-reforço, foi verificar que, mesmo depois de o estado deficitário ter sido normalizado, as abelhas continuavam a coletar preferencialmente o mesmo alimento. Ou seja, abelhas que foram criadas sem mel, passaram a pegar mel preferencialmente e, mesmo depois de terem normalizado os níveis de mel na colônia, elas continuavam a coletar mel. Os autores discutiram que esse comportamento surgiu através do auto-reforço ao estímulo de coletar o alimento da primeira vez.

Ao associar todos esses diferentes modelos de como insetos eussociais dividem as tarefas de manutenção do ninho é possível concluir que os padrões coletivos observados dependem de fatores tanto internos quanto externos aos indivíduos. Os diversos fatores que foram apresentados e discutidos incluem: (1) captação de informação e percepção de estímulos pelos indivíduos; (2) transmissão da informação entre os indivíduos; (3) fatores ambientais que modulam a intensidade dos estímulos; (4) regras intrínsecas do sistema social (i. e. auto-organização); (5) fatores genéticos e 
ontogenéticos de determinação de resposta aos diferentes estímulos (i.e. limiares). Alguns fatores citados acima dizem respeito a características inerentes aos indivíduos, outros dizem respeito ao ambiente no qual esses indivíduos estão inseridos. A figura 2 sintetiza como esses diferentes aspectos da organização social influenciam na coordenação dos diversos comportamentos de manutenção das colônias de insetos eussociais (BESHERS \& FEWELL, 2001).

Note que a resposta comportamental coletiva é a somatória das respostas dadas pelos indivíduos. Note também que existem fatores que independem dos indivíduos pertencentes à colônia, mas que influenciam na resposta coletiva. Pelos vários motivos elencados acima se argumenta que colônias de insetos eussociais podem ser tratadas como superorganismos. É possível a compreensão de certos aspectos das respostas comportamentais e fisiológicas de organismos multicelulares através da análise das partes que compõe esse organismo (i. e, órgãos e células). Mas, isso só faz sentido quando contextualizado para o sistema completo. Inclusive, existem propriedades que são observadas apenas no contexto do individuo como um todo, mas não do contexto das partes constituintes, como as alças de retroalimentação dos sistemas fisiológicos. Da mesma forma, em insetos eussociais, é possível a compreensão dos comportamentos coletivos analisando apenas os indivíduos que compõe a colônia. Entretanto, a complexidade da eusocialidade e diversos aspectos organizacionais são observados apenas quando todo o contexto social é levado em consideração.

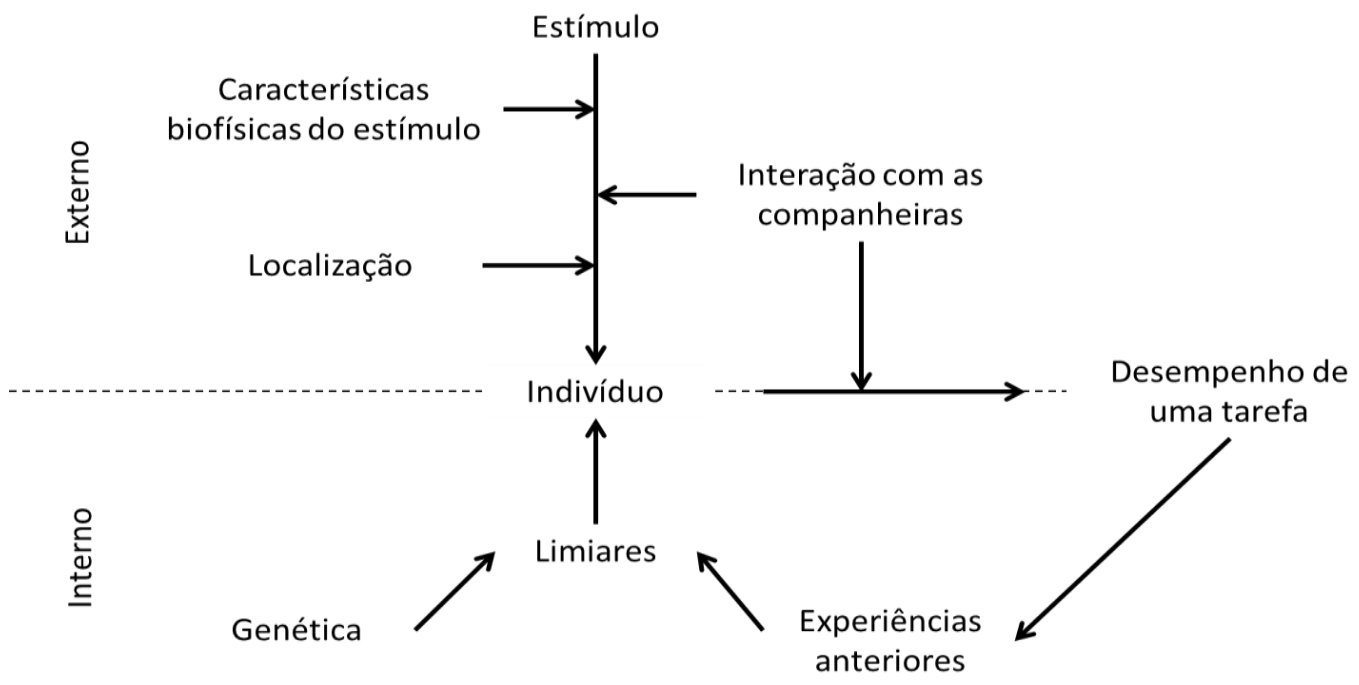

Figura 2: como os diferentes aspectos individuais, coletivos e ambientais modulam o desempenho das diversas tarefas. Modificado de Beshers \& Fewell, 2001. 


\subsection{Biologia das formigas saúvas}

Dentre todos os insetos eussociais as formigas saúvas apresentam uma série de características que a tornam um modelo interessante para o estudo das relações interindividuais em uma sociedade. Colônias de formigas do gênero Atta alcançam tamanhos gigantescos e podem possuir milhões de indivíduos. A estrutura da colônia subterrânea, assim como o número de indivíduos, pode se tornar enorme, alcançando um diâmetro de mais de 25 metros e profundidades de mais de 10 metros (AUTUORI, 1950). Em termos de proporção, não há nenhuma estrutura construída pela humanidade que seja comparável.

Além de proporções enormes em número de indivíduos e tamanho, as saúvas também apresentam outra característica que influência no comportamento social. Elas são formigas agricultoras e apresentam simbiose obrigatória com um fungo. As operárias cultivam em câmaras internas da colônia um fungo basidiomiceto. Esse fungo cultivado é a principal fonte de proteína na dieta dessas formigas. Essa relação simbiótica com o fungo implica em outra característica única das saúvas. Como o fungo é cultivado pelas formigas, elas devem buscar recursos a fim de cultivar devidamente esse recurso. Uma vez que o fungo cultivado possui a maquinaria molecular para a degradação de celulose, os recursos utilizados para a manutenção do jardim de fungos são principalmente folhas de diversas espécies vegetais. Com essa relação simbiótica as formigas obtém uma fonte de proteínas em troca da constante implementação de material vegetal para o desenvolvimento do fungo. Tal característica rendeu o nome de 'formiga cortadeira' à esse clado de formigas que cultivam fungos e coletam recursos foliares. Não obstante, dada essa simbiose e o tamanho descomunal das colônias, essas formigas cortadeiras são consideradas pragas agrícolas e causam prejuízos significativos aos cultivares humanos (WEBER, 1972).

Tanto os tamanhos das colônias, como a extensão de seus ninhos, como a simbiose com o fungo e como o polimorfismo das operárias implicam em uma serie de atributos à organização social dessa espécie. Essas implicações serão mais detalhadas nas seções a seguir. 


\subsubsection{Divisão de castas morfológicas}

Como citado anteriormente, as operárias de formigas saúva apresentam um polimorfismo extremo. Em uma colônia o comprimento da cabeça das operárias varia de forma contínua entre $0,6 \mathrm{~mm}$ e 3,6 mm. Dessa forma, não existe uma definição clara entre possíveis subcastas nesse espectro de tamanho de cabeça, caso seja considerado apenas a morfologia das formigas. Entretanto, uma característica notável das saúvas é que a morfologia apresenta um forte correlato com os comportamentos desempenhados na colônia. Wilson em 1980 descreveu essa correlação entre forma e função e propôs a divisão das operárias de saúva em 4 castas morfofuncionais. São elas as: (1) enfermeiras ( $<0,6 \mathrm{~mm}$ a $1,2 \mathrm{~mm})$, responsáveis pelo cuidado com a rainha, larvas e pupas; (2) médias generalistas internas $(1,3 \mathrm{~mm}$ a $2,0 \mathrm{~mm})$, responsáveis pelo cuidado interno do jardim de fungos, como processamento secundário do material vegetal a ser implantado e gerenciamento dos resíduos; (3) forrageadoras $(2,1 \mathrm{~mm}$ a 2,9mm), responsáveis pela escavação de tuneis e galerias, pela exploração de novos territórios e pelo corte e transporte de folhas; e (4) soldados $(>3,0 \mathrm{~mm})$, responsáveis pela defesa da colônia contra possíveis invasores (WILSON, 1980a).

Tal organização morfofuncional poderia ser explicada pelos diversos modelos de divisão de tarefas citados anteriormente, como a auto-organização. Note que a organização social das saúvas também não apresenta organização hierárquica de comando, portanto, respeita a premissa do modelo de auto-organização. Ou seja, as formigas dividem as tarefas dessa forma simplesmente porque existe alguma regra que determina que esse padrão aflore da relação dos indivíduos polimórficos.

A organização das saúvas também é condizente com os modelos de limiares. É plausível argumentar que os limiares sejam diferentes para as formigas de diferentes tamanhos. Tal modelo se torna ainda mais coerente quando é observado que formigas médias generalistas e enfermeiras são capazes de desempenhar a tarefa de corte e transporte de vegetação, quando as forrageadoras são removidas artificialmente da colônia (WILSON, 1983a). Dessa forma, constata-se que todas as formigas possuem os repertórios comportamentais completos para desempenhar todas as tarefas de manutenção da colônia. Entretanto, elas não o fazem devido a alguma regra inerente às formigas. 
Já foram estudados alguns mecanismos biológicos de desenvolvimento visando a compreensão das características que levam a expressão desse polimorfismo tão extremo. Por exemplo, uma vez que as rainhas de formigas cortadeiras são fecundadas por diversos machos, talvez as diferentes linhagens paternais sejam determinantes para o desenvolvimento das diferentes castas. De fato, é possível encontrar essa relação, como observado por Hughes, et al. (2003), entretanto, ela não explica totalmente a variedade de morfologias encontradas. Portanto, o desenvolvimento das diferentes castas polimórficas depende de fatores genéticos e de fatores ambientais.

\subsubsection{Divisão ergonômica de tarefas}

Mais do que simplesmente dividir as formigas operárias de saúvas em castas morfofuncionais, Wilson (1980b) estudou do ponto de vista energético o porquê esse padrão de divisão de tarefas emergia. O que foi observado é que as formigas de diferentes tamanhos possuíam eficiências diferentes na realização das diversas tarefas de manutenção da colônia. A divisão morfofuncional proposta segue um padrão de otimização no gasto de energia (WILSON, 1980b). Ou seja, as formigas de diferentes tamanhos alocam-se nas tarefas cuja eficiência é a melhor. Dessa forma, é possível afirmar que as formigas saúvas dividem as tarefas entre as operárias polimórficas de maneira ergonômica.

Aparentemente a regra que define a divisão de tarefas, nesse caso, diz respeito a otimização do gasto de energia por parte da colônia como um todo, o que é condizente com o modelo de auto-organização. Mesmo com essas evidências acerca das diferenças na eficiência energética no desempenho das diferentes tarefas por formigas de diferentes tamanhos, não é possível descartar completamente o modelo de limiares. Isso porque, de fato, o polimorfismo entre as operárias pode estar intimamente associado a diferenças na resposta aos estímulos que percorrem a colônia (SCHWANDER et al., 2005).

Uma vez que as formigas saúvas se distribuem em um contínuo de tamanhos, a classificação em diferentes castas poderia ser feita de diversas maneiras. Entretanto, o que torna o modelo morfofuncional proposto por Wilson tão robusto é a soma de 3 
fatores na categorização das castas das saúvas: (1) morfologia, (2) função e (3) eficiência energética no desempenho dos comportamentos.

Como é de se esperar, é extremamente complexo definir quais as origens evolutivas do polimorfismo: justamente porque a expressão desse polimorfismo ocorre nos indivíduos que perderam a capacidade de reproduzir. Porém, é razoável afirmar que, em um contexto evolutivo, aquelas colônias que apresentavam polimorfismo e dividiam ergonomicamente as tarefas obtiveram vantagem sobre aquelas que não apresentavam polimorfismo (HARVELL, 1994).

Por outro lado, é possível argumentar que a especialização no desempenho de tarefas por formigas polimórficas poderia diminuir a flexibilização necessária para a manutenção da colônia em ambientes não estáveis. Tal comparação levanta a questão ecológica da relação de custos e benefícios de duas estratégias diferentes: especialização versus generalização (POWELL, 2009). Essa relação, apesar de ser extremamente relevante para a compreensão das diferentes organizações sociais, ainda não está bem esclarecida. Mas é plausível a afirmação de que as estratégias de especialização e generalização tenham desempenhado um papel fundamental na evolução das diferentes espécies de formigas, visto que o polimorfismo aparentemente surgiu independentemente diversas vezes na família Formicidae.

Outra característica fascinante do polimorfismo encontrado em saúvas é a alometria de diferentes estruturas. Ainda que o polimorfismo em saúvas apresente um contínuo de tamanhos possíveis para a largura da cabeça, outras estruturas do corpo não crescem nas mesmas proporções, como é o caso das antenas. As antenas de formigas maiores, notadamente pertencentes à casta das soldados, tendem a ser proporcionalmente menores que a antena de formigas menores (WILSON, 1983a). Tais diferenças morfométricas podem representar aspectos especializados das diferentes castas. Como discutido pelo autor, talvez antenas proporcionalmente grandes como a cabeça em soldados poderiam apresentar um problema para o desempenho correto das tarefas associadas a essa casta (Lopes, et al., 2013).

Apesar das inúmeras implicações, as características morfológicas são imprescindíveis para a organização social das saúvas. O polimorfismo observado representa uma regra definidora no processo de divisão de tarefas. Além disso, ele apresenta uma série de implicações fisiológicas (eficiência na performance de tarefas), 
ontogenéticas (processo de diferenciação morfológica) e evolutivas (evolução do caractere de polimorfismo) para a sociedade das saúvas.

\subsubsection{Tarefa de forrageamento}

Dentre as inúmeras tarefas desempenhadas pelas saúvas, uma em específico chamou a atenção dos pesquisadores em função dos vários aspectos que podem influenciar no comportamento: a formação de trilhas de forrageamento. Uma característica marcante das trilhas de forrageamento de saúvas é a extensão que elas podem alcançar. Existem descrições de que essas trilhas podem se estender por mais de 150 metros (HOWARD, 2001). Obviamente que, construir e coordenar a atividade de formação de trilhas tão compridas requer das formigas a superação de diversos desafios. Portanto, o forrageamento das saúvas apresenta um ótimo modelo para diversos aspectos do estudo do comportamento, tanto individual quanto coletivo para superação de desafios como: localização espacial, comunicação entre os indivíduos, transferência de informação, recrutamento e diversos outros.

Um dos aspectos, que merece especial atenção, diz respeito a como as saúvas são capazes de se localizar no espaço. O inicio da formação de uma trilha de forrageamento depende da tarefa exploratória de algumas formigas, que saem do ninho em busca de alimento. Os modelos mais recentes indicam que essas formigas exploradoras saem da colônia percorrendo um caminho aleatório em busca de alimento. Durante o percurso as exploradoras se utilizam de diversos mecanismos integradores de informação a fim de acompanhar a direção da entrada do ninho, como mapeamento das pistas visuais no caminho, posição relativa do sol, manutenção de um vetor endógeno de direção e até mesmo contagem de passos (CHERRETT, 1968; ROCES, 2002; KNADEM \& GRAHAM, 2016). Note que os exemplos de mecanismos citados foram descritos em formigas de várias espécies diferentes. É esperado que nem todos os mecanismos estejam presentes nas saúvas em específico, mas também é razoável dizer que existe a possibilidade de que esses diversos mecanismos, quando existentes, sejam utilizados conjuntamente.

Uma vez que o alimento foi encontrado, as formigas saúvas, integrando as informações obtidas durante o percurso, voltam para a colônia seguindo uma 'linha reta' 
(i.e. um caminho mais curto possível em um ambiente irregular). A saúva que obteve sucesso em encontrar o alimento volta depositando no substrato um feromônio atrativo para as outras formigas da colônia. Dessa forma, ao chegar no ninho, outras formigas são compelidas a seguir a trilha depositada por aquela exploradora e, eventualmente, elas chegam à fonte de alimento. Conforme mais formigas transitam por aquele caminho, mais feromônio é depositado, e mais formigas são atraídas àquele caminho, em um mecanismo de retro-alimentação positiva. Dessa forma, as saúvas conseguem coletivamente encontrar a fonte de alimento mais adequada na menor distância possível (CZACZKES, 2015).

Assim que a trilha está estabelecida, outros mecanismos individuais e coletivos começam a funcionar de modo a modular e maximizar a atividade de forrageamento. Por exemplo, já foi descrito que o número de contatos que os indivíduos trocam enquanto percorrem a trilha de forrageamento codifica para uma informação sobre o fluxo total (BOUCHEBI et al., 2015). Não apenas as informações coletivas são utilizadas na navegação pelas trilhas de forrageamento. Foi demonstrado que a memória sobre forrageamentos passados e a motivação acerca da aquisição de alimentos são capazes de modular o limiar de resposta aos feromônios de trilha (ELIZALDE \& FARJI-BRENER, 2012; VON THIENEN, et. al, 2016). Ou seja, mesmo com a trilha já estabelecida, diversos processos modulam a atividade nas trilhas.

Outra característica das saúvas, que argumenta-se que aumenta a eficiência na coleta de alimento, diz respeito ao particionamento da tarefa de forrageamento. $\mathrm{O}$ sucesso na coleta de alimentos depende de algumas etapas, como o corte de folhas e o transporte dos fragmentos de volta para a colônia. Foi descrito que as saúvas particionam a tarefa de forrageamento em subtarefas. Algumas operárias sobem nos arbustos, cortam os fragmentos de folha e deixam cair nas proximidades das raízes; enquanto outras formigas permanecem embaixo, coletam esses fragmentos e os transportam para a colônia (HART \& RATNIEKS, 2001; HART et al., 2002).

Entretanto, dentre todos os desafios que as formigas podem enfrentar ao sair do ninho, as condições ambientais externas talvez sejam os desafios mais óbvios, porém os menos estudados. Algumas descrições esporádicas sobre como as condições abióticas influenciam no comportamento de forrageamento podem ser encontradas e observações feitas em outros animais podem ser extrapoladas para formigas. Por exemplo, é razoável assumir que, assim como outros insetos, que evitam permanecer no sol durante muito 
tempo a fim de evitar o dessecamento, as formigas não formariam trilhas durante os picos de temperatura. De fato, tal padrão foi observado por Cherrett em 1968: ao meio dia não eram observadas saúvas nas trilhas, enquanto que nos outros horários, que possuíam temperaturas mais amenas, eram observadas formigas transitando pelas trilhas. Fowler e Robinson (1979) foram além e descreveram que as saúvas podem forragear sim durante o meio do dia, entretanto o fazem apenas nos meses de inverno.

Outro desafio ambiental já estudado em saúvas diz respeito a umidade relativa do ar preferencial de forrageio. Saúvas preferem forragear em ambiente cuja umidade relativa do ar é maior. Novamente, nesse caso, é discutido que a dessecação seja um fator impeditivo da formação de trilha de forrageamento (Dados do laboratório não publicados).

Essas descrições esporádicas não fornecem dados suficientemente satisfatórios para discutir quais são as estratégias, processos e comportamentos sociais adotados pelas saúvas para transpor os desafios ambientais das condições abióticas do ambiente externo ao ninho. Entretanto, tanto temperatura, como umidade relativa do ar, variam de forma cíclica no ambiente e conjuntamente com as variações de luz ao longo do ciclo claro-escuro.

Como será discutido na seção posterior, as características cíclicas apresentamse como um ótimo modelo para o estudo dos comportamentos, pois são passiveis de serem previstas e funcionam como um marca-passo para os osciladores endógenos, mais conhecidos como relógios biológicos. O estudo dessas características cíclicas e o comportamento se torna mais interessante no contexto eussocial, uma vez que os indivíduos de uma colônia devem sincronizar-se não apenas com os ritmos ambientais, mas também com seus companheiros. Dessa forma, adiciona-se uma camada de complexidade ao tópico por envolver tanto aspectos ambientais quanto sociais.

\subsection{Aspectos cíclicos do ambiente e ritmicidade biológica}

\subsubsection{Ritmos ambientais}

Os desafios ambientais enfrentados pelos animais podem ser apresentados de duas maneiras diferentes: previsível ou imprevisivelmente. Os desafios imprevisíveis dizem respeito a eventos aleatórios que podem ocorrer no decorrer da vida de um 
organismo. Já os desafios previsíveis dizem respeito às inúmeras variações cíclicas que acontecem no ambiente. Esses ritmos ambientais podem ser caracterizados pelo seu período. O ritmo de claro e escuro, representado pelo dia e a noite tem período de 24 horas, já as diferentes estações do ano tem período de 1 ano.

O ciclo de claro-escuro, além das variações de luminosidade, traz consigo uma série de outras características ambientais que oscilam com o mesmo período. Temperatura e umidade relativa do ar são exemplos de fatores abióticos que oscilam conjuntamente com a luminosidade. Dessa forma, diversas informações ambientais codificam para a mesma informação de ciclo, e os diferentes organismos podem utilizar-se dessas informações para coordenar suas funções internas e comportamentos.

De fato, os ritmos ambientais parecem tão importantes na expressão dos comportamentos animais que é comum a associação de um padrão comportamental de atividade a uma determinada hora do dia. As classificações dos animais como diurnos ou noturnos representam essa intimidade entre os ritmos ambientais e os comportamentos animais. Dessa forma, é razoável afirmar que os animais possuem um sistema que permite a sincronização de suas funções internas com os ritmos ambientais. Extensa literatura na área de cronobiologia corrobora essa afirmação. De fato os animais possuem um oscilador endógeno, comumente conhecido como relógio biológico, capaz de sincronizar os ritmos endógenos com os ritmos ambientais. As características e mecanismos adjacentes do oscilador endógeno e os processos de sincronização serão mais bem discutidos na seção a seguir (MARQUES, 1997; DUNLAP, 2004).

\subsubsection{Ritmicidade endógena}

Ao analisar as diversas variáveis fisiológicas em escala temporal, é possível perceber que, mesmo em condições normais (i.e. sem qualquer quadro fisiopatológico) elas oscilam ao longo das 24 horas do dia. Temperatura corpórea, liberação de cortisol, secreção de aminoácidos na urina, concentração de hormônios gonadais no plasma sanguíneo, comportamento de atividade e diversas outras variáveis oscilam ritmicamente ao longo do dia. Esses padrões poderiam surgir de duas formas: (1) essas variáveis respondem aos ciclos ambientais; ou (2) elas oscilam naturalmente sem a 
necessidade do input de informações ambientais. O que se observa nos organismos é a segunda hipótese.

Quando é retirado o estímulo ambiental, ou seja, quando os animais são colocados em condições ambientais que não variam ao longo do tempo, fica claro que essas variáveis fisiológicas continuam oscilando. Entretanto, o período de oscilação, apesar de ser próximo à 24 horas, não é exatamente de 24 horas. Mais ainda, todas as variáveis fisiológicas continuam oscilando juntas, ou seja, mesmo sem o ritmo ambiental para sincronizar todas as variáveis fisiológicas internas, elas continuam oscilando conjuntamente. Essa condição na qual as oscilações das variáveis fisiológicas oscilam sem o input de informação ambiental é chamado de livre curso. Hoje se sabe que existe um oscilador central responsável por essas duas características das oscilações internas: (1) sincronização com o ritmo ambiental e (2) manutenção da oscilação mesmo em condições ambientais constantes (ASCHOFF, 1960).

Em condições ambientais constantes o oscilador central cicla com período próximo a 24 horas. Discute-se que essa característica é essencial para que o oscilador endógeno seja passível de ser sincronizado com os ritmos ambientais. Portanto, é dito que o ritmo do oscilador endógeno, quando em livre curso, é circadiano, ou seja, próximo a 24 horas. Além disso, o período no qual esse oscilador cicla é constante e determinado por características genéticas. Quando em livre curso o período do oscilador endógeno recebe a denominação tau $(\tau)$. Em um actograma (gráfico que representa a atividade ao longo do tempo) observa-se o $\tau$ em livre curso como pequenos adiantamentos ou atrasos no momento do inicio da fase de atividade (PITTENDRIGH \& DAAN, 1976).

Uma vez que existem vários ritmos ambientais oscilando conjuntamente, qualquer um deles poderia ser utilizado como input de informação para o oscilador endógeno. De fato, em diversos animais é possível observar que diferentes modalidades sensoriais são utilizadas para sincronizar o oscilador endógeno com os ritmos ambientais. Ao ritmo ambiental que é capaz de sincronizar o oscilador endógeno é dado o nome de zeitgeber. Entretanto, as pesquisas indicam que o principal zeitgeber é dado através da presença/ausência de luz cíclicas ao longo do dia.

É inegável que essas oscilações nas variáveis fisiológicas têm uma grande importância evolutiva, dada a sua abrangência nos táxons vivos. Justamente por isso 
existem várias teorias que explicam qual seria a função dessas oscilações. É discutido que essas variações rítmicas criam dois estados fisiológicos nos organismos: atividade e repouso. No estado de atividade os indivíduos podem ativamente buscar recursos para sua manutenção. Já no estado de repouso os organismos apresentam uma condição de reparação e restauração de funções fisiológicas. Não obstante, é nítido o déficit na execução de determinadas tarefas em indivíduos que foram privados da etapa de repouso. Portanto, parece razoável afirmar que um ciclo de atividade/repouso é necessário para o aumento no desempenho de determinados comportamentos (DUNLAP, 2004).

Apesar de a capacidade de sincronizar os ritmos internos com os ritmos ambientais ser difundida na maioria dos táxons vivos, os mecanismos pelo qual esse efeito acontece são variados. Em mamíferos, a luz, principalmente nos comprimentos de onda referentes à cor azul, é percebida por pigmentos receptores específicos, a melanopsina, nas células ganglionares da retina (BUHR et al, 2015). Essa informação segue uma rede neural separada daquela envolvida na visão e a informação é levada ao núcleo supraquiasmático logo acima do quiasma ótico no hipotálamo medial. O núcleo supraquiasmático é tido como o oscilador central dos mamíferos. É esse grupo de neurônios que, mesmo em livre curso, sinaliza para as células da glândula pineal a liberação rítmica do hormônio melatonina. Entretanto, quando na presença de luz, a liberação de melatonina é inibida, o que cria o sincronismo com o zeitgeber. Assim, a melatonina é liberada apenas na fase de escuro (MARQUES, 1997). Vale ressaltar que independente do mamífero estudado, seja ele diurno ou noturno, a melatonina será liberada apenas na fase de escuro. Portanto, o que determina se o animal é diurno o noturno depende da relação que os diferentes tecidos apresentam ao se ligar à melatonina.

Em insetos, é sabido que o sistema nervoso central é o principal responsável pelos diversos comportamentos, inclusive o de atividade locomotora. Entretanto, não se conhece ainda uma estrutura bem definida que pode ser chamada de oscilador central. Também não é conhecido o mecanismo de transdução das condições luminosas em informação para o oscilador. Aparentemente podem existir múltiplas estruturas fotorreceptoras e múltiplos relógios espalhados pelo corpo, como descrito em Drosophila melanogaster (PLAUTZ, 1997). Porém, é bem descrita a base molecular do relógio biológico em insetos. O mecanismo que origina a oscilação é baseado em 
diversos genes que se interligam e funcionam como alças regulatórias deles mesmos. Em D. melanogaster o produto dos genes clock e cycle (CLK e CYC, respectivamente) se dimerizam e formam um fator de transcrição para os genes period, timeless, vrille e PAR domain protein 1 ( $P d p 1)$. Por sua vez, os produtos de period e timeless interagem com o dímero CLK/CYC e inibem a função de fator de transcrição. Em outras palavras, o dímero PER/TIM regula a sua própria transcrição. Dessa forma, é possível observar naturalmente essas alças de regulação resultando em um padrão de autorregulação. $O$ dímero PER/TIM também atuam na expressão de vri e pdpl. As proteínas desses genes VRI e PDP1 ligam-se à região promotora do clock, entretanto VRI é um repressor da expressão enquanto PDP1 é um inibidor. Consequentemente, esses dois produtos acumulam-se diferencialmente nas fases de claro e de escuro: VRI acumula-se no inicio da fase de escuro e PDP1 no meio da fase de escuro. Como eles se acumulam em fases diferentes e possuem funções diferentes, a resultante dessa interação entre esses genes induz a expressão rítmica de CLK, CYC, de PER e TIM. Essa alça genica é capaz de ser sincronizada com o ritmo ambiental através da interação com outra proteína: cryptochorme (produto: CRY). Quando CRY é submetido à luz ele se torna ativo ligando-se a TIM, fosforilando-o e inativando-o. Dessa forma, a alça de autorregulação de PER e TIM é atrasada e, portanto, sincronizada com o ritmo ambiental. O PER que não se liga ao TIM acaba ligando-se à proteína DBT (proveniente da expressão do gene double time) e é marcado para uma via de degradação. Quando o estímulo da luz é ausente durante a noite, não ocorre a ativação de CRY, o TIM pode se ligar ao PER e continuar o ciclo de expressão autorregulável. Novamente vale ressaltar que essa relação da inibição através do CRY é comum tanto para insetos noturnos quanto para insetos diurnos. O que muda é a relação sinalização que os tecidos apresentam com esse padrão (HARDIN et al.,1990; EMEREY et al., 1998, HARDIN, 2011).

Esse modelo foi descrito para Drosophila sp. e pode ser extrapolado para diversos outros insetos. Inclusive, esses genes do relógio tendem a ser muito conservados ao longo dos grupos de insetos. Entretanto, os mecanismos e os padrões das alças podem variar consideravelmente entre as diversas famílias de insetos (revisado por SANDRELLI et al., 2008).

Assim como não é bem conhecido os mecanismos de transdução da luz como informação para os relógios biológicos em insetos, também não estão claros quais são os efetuadores que transmitem a informação do relógio para os diferentes tecidos do 
corpo. O hormônio juvenil (JH), que é o principal hormônio coordenador dos processos fisiológicos e comportamentais em insetos, aparentemente não influencia na ontogenia da ritmicidade em abelhas (BLOCH et al. 2002). Portanto, ainda são necessários esclarecimentos acerca das vias de transdução e efetuação das informações ambientais para o oscilador endógeno e do oscilador para os tecidos do corpo do inseto.

\subsection{Dilema da ritmicidade coletiva}

Os modelos, padrões e processos citados acima dizem respeito a diferentes indivíduos. Entretanto, como discutido na primeira parte desse texto, quando é utilizado o modelo social, como nas formigas, é necessária também a análise em outro nível de organização: o coletivo. Espera-se, portanto, que formigas apresentem individualmente seus próprios ritmos de atividade, já que essa característica é individual e codificada por fatores genéticos. Espera-se também que a colônia (nível de análise coletivo) apresente um padrão de atividade próprio que seja relacionado aos padrões dos indivíduos que a constituem. De fato, padrões rítmicos de atividade já foram descritos para algumas espécies de formigas. Formigas Camponotus paria são diurnas, ou seja, apresentam maior atividade tanto individual quanto coletiva na fase de claro (LONE, 2011), assim como Formica cunicularia e Camponotus aethiops (YILMAZ et al. 2014). CHERETT (1968) descreveu que formigas Atta colombica forrageiam na fase de escuro. Portanto, os relatos da literatura indicam que as várias espécies de formigas podem apresentar diferentes padrões de atividade em relação às condições ambientais.

Arruda et al. (2016) demonstrou que formigas saúvas Atta sexdens apresentam coletivamente preferência por forragear durante a fase de escuro, quando elas são mantidas em condições ambientais constantes e fotoperíodo de 12:12 LD. Entretanto, essa preferencia não implica em exclusividade. Um número significativo de formigas foi observado forrageando durante a fase de claro. Em outras palavras, formigas saúvas formam trilhas de forrageamento que permanecem ativas 24 horas por dia até o esgotamento da fonte de alimento, mas com diferenças na atividade da trilha em claro e em escuro.

Dois extremos de organização podem explicar como esse padrão de forrageamento contínuo pode surgir: (1) as formigas individualmente são arrítmicas, o que levaria ao tráfego constante de operárias na trilha, independente das condições 
ambientes de luminosidade, ou (2) as formigas se organizam coletivamente em turnos de atividade, o que levaria subdivisão da tarefa de forrageamento em turnos de atividade diurno e noturno.

Do ponto de vista fisiológico, parece mais plausível a hipótese de que as formigas se dividem em turnos de atividade. Isso porque, como demonstrado extensamente em várias outras espécies, a esmagadora maioria das espécies estudadas apresentam algum ritmo sincronizado com as condições fóticas. No contexto das espécies eussociais, Sharma et al. (2004a) demonstrou em formigas Camponotus compressus um possível evidência para a existência desses turnos de atividade. Quanto medida a atividade de formigas desta espécie mantidas em condições constantes com fotoperíodo 12:12 LD foi verificada a existência de dois padrões: formigas diurnas e formigas noturnas. Essas mesmas formigas foram então transferidas para condição de escuro constante e seus ritmos de atividade entraram em livre curso. Em livre curso observou-se que as formigas apresentavam o $\tau$ variável. Após 22 dias do inicio da condição de livre curso o $\tau$ invertia de $>24 \mathrm{~h}$ para $<24 \mathrm{~h}$ ou vice-versa. Com essas evidências, os autores argumentaram que essas formigas apresentavam dois padrões de atividade: noturno e diurno; e que esses padrões se invertiam ao longo do tempo. Ou seja, além de apresentarem turnos de atividade essas formigas também realizariam troca do turno (figura 3).

Apesar dos resultados consistentes, os dados foram coletados em formigas individualizadas sem o contato social com as companheiras. Uma vez que as formigas são espécies exclusivamente eussociais, as análises dos aspectos coletivos de divisão temporal de tarefas se fazem necessários. Ou seja, visto que as formigas podem apresentar ritmos de atividade diferentes, como esses ritmos se integram em um padrão coletivo de divisão de tarefas.

Uma vez que a interação com o ambiente, em especial com as variações cíclicas de certas condições abióticas, é um fator chave para o desempenho de certos comportamentos, compreender como se dá a interação dos indivíduos de uma colônia com essas condições cíclicas se torna um objeto de estudo relevante. No caso específico das saúvas, como os diversos indivíduos da colônia coletivamente organizam a tarefa de forrageamento ao longo do tempo, já que, aparentemente as formigas permanecem 
constantemente na trilha? A descrição desse padrão pode ampliar as concepções sobre os padrões individuais de atividade e sua expressão nas sociedades dos insetos.
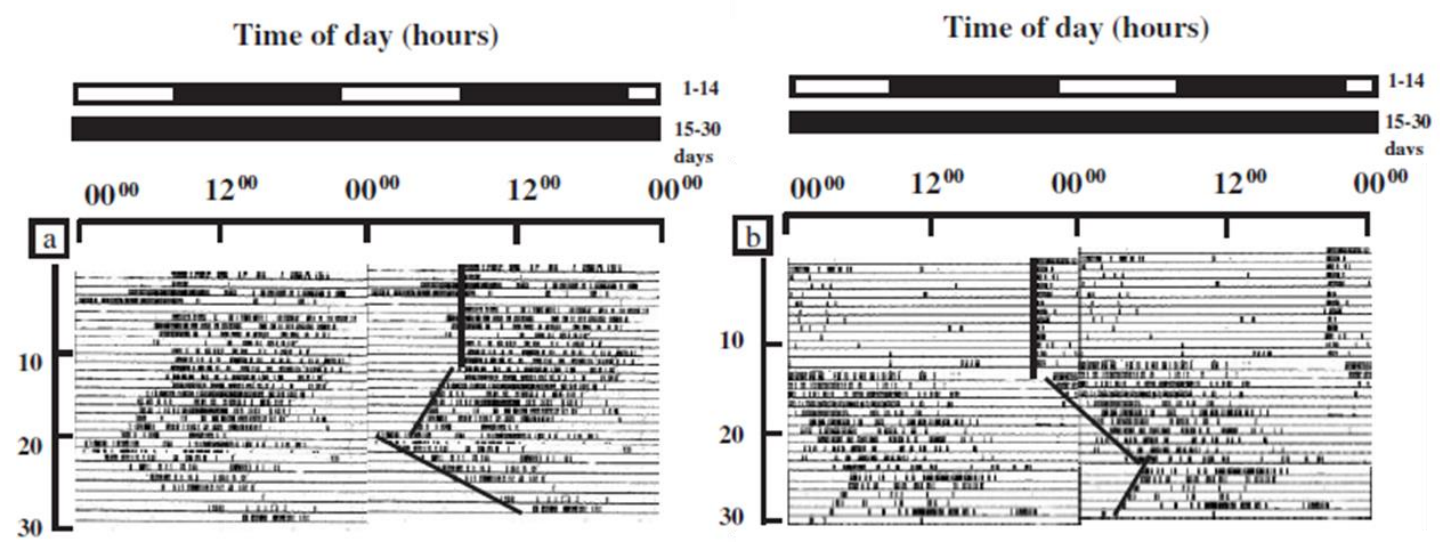

Figura 3: actogramas de formigas (a) noturnas e (b) diurnas de uma mesma colônia de Camponotus compressus. Note a mudança de tau próximo ao dia 20. Retirado de SHARMA et al., 2004.

Os comportamentos de atividade são modulados pelos osciladores endógenos. A informação que esses osciladores codificam para os tecidos são dadas por características genéticas. Espera-se, que organismos geneticamente semelhantes, como as formigas de uma mesma colônia, apresentem padrões de atividade semelhante. Portanto, parece contra intuitivo, baseando-se na extensa literatura acerca da temática, que indivíduos não apresentem certo ritmo de atividade/repouso. Entretanto, o que se observa nas trilhas de formigas saúvas é que existem operárias transitando independentemente das condições ambientais. Como as saúvas constituem uma espécie eussocial, que divide as diversas tarefas de manutenção do ninho entre as operárias, foi elaborada a hipótese de que elas seriam capazes de dividir a tarefa de forrageamento ao longo do dia. Espera-se, caso essa hipótese seja corroborada, que existam grupos de operárias que forrageiam em fases diferentes e alternadas. De maneira similar ao que seria chamado de turno de trabalho.

A proposta da presente dissertação é, portanto, apresentar e discutir em termos da coletividade das formigas como ocorre a divisão temporal de tarefas nas trilhas de forrageamento de formigas saúvas. Para tanto, também se faz necessária a descrição de alguns aspectos inerentes da trilha de forrageamento e das operárias que por ela transitam a fim de explicitar os fatores que influenciam no padrão já descrito para saúvas. 


\section{Hipóteses e previsões}

Até agora foram apresentadas as particularidades de cada individuo que pertence a uma organização eussocial e como a interação dos indivíduos faz surgir alguns aspectos que só podem ser observados do ponto de vista coletivo. A relação entre os indivíduos e o coletivo com o ambiente também foi explicitada; com especial enfoque nos aspectos cíclicos. Levantou-se a problemática na qual o padrão de forrageamento de formigas saúvas não se encaixa nos modelos individuais e coletivos de ritmos endógenos passíveis de serem sincronizados com os ritmos ambientais. Nesse contexto levanta-se a hipótese de que as formigas saúvas dividem a tarefa de forrageio, que é executada 24 horas por dia, em turnos de trabalho.

Do ponto de vista comportamental, a divisão temporal de tarefas se traduziria em grupos de formigas que forrageiam em horários diferentes ao longo do dia. Do ponto de vista do coletivo espera-se que o padrão de atividade da colônia seja relacionado aos padrões comportamentais dos indivíduos que a constituem.

Uma vez que as formigas dividam a tarefa de forrageamento em turnos de trabalho, uma serie de consequências que podem emergir dessa organização podem ser estudadas. Uma delas diz respeito as diferenças que essas formigas podem apresentar. Como saúvas são polimórficas e o polimorfismo está associado ao processo de divisão de tarefas, levanta-se a hipótese que existam diferenças morfológicas nas formigas que forrageiam em diferentes fases. Dadas as relações entre o tamanho corpóreo e a resistência térmica, espera-se que as formigas que forrageiam de dia sejam maiores que as formigas que forrageiam de noite.

Se de fato as formigas que forrageiam em diferentes fases são diferentes entre si, as regras de interação entre elas podem ser diferentes. Isso se traduziria em dois estados diferentes da colônia em função do ritmo claro/escuro. É possível que, dadas essas diferenças, a colônia se comporte de maneira diferente no claro e no escuro. Uma possibilidade de análise desses dois estados diferentes pode ser avaliando a relação entre a atividade da colônia (i.e fluxo na trilha) e a coleta de alimento (i. e. fragmentos de folhas transportados). Nesse caso hipotetiza-se que a maior eficiência de forrageamento seja no estado no qual a colônia está mais ativa. Espera-se, portanto, que a colônia adquira a maior quantidade de recursos alimentares na fase cujo numero de formigas ativas seja maior. 


\section{Objetivos}

\subsection{Gerais}

O objetivo dessa dissertação é descrever como se dá o padrão de divisão temporal de tarefas em turnos de trabalho de formigas Atta sexdens rubropilosa. A descrição de tal padrão será avaliado por meio da observação da presença de indivíduos marcados e de seus dos turnos de trabalho observados em diferentes horários do ciclo de 24h. Com isso espera-se que seja possível avaliar não apenas a fidelidade da ocorrência dos indivíduos marcados em horários específicos, mas também seus padrões de trabalho ao longo das fases de claro/escuro.

Existem alguns aspectos que são inerentes a essa organização temporal coletiva e que merecem ser avaliados. Uma vez que as saúvas apresentam alto grau de polimorfismo e que essa característica está relacionada ao processo de divisão de tarefas, é possível que existam diferenças na morfologia das formigas que aparecem nas diferentes fases do dia. Portanto, é válida a investigação da morfologia das formigas que são observadas em diferentes fases.

Do ponto de vista coletivo a atividade de uma colônia pode ser definida como o fluxo de formigas observadas na trilha. Já que as colônias de saúva se mostram com o padrão de atividade noturno, mas não cessam sua atividade na fase de claro, é possível discutir a eficiência diferencial na aquisição de recursos alimentares nessas duas condições de iluminação. Esse é outro exemplo de uma característica coletiva que emerge da interação dos indivíduos e seus ritmos de atividade.

\subsection{Específicos}

Para uma avaliação completa de como se dá o padrão coletivo de divisão temporal de tarefas em turnos de trabalho é necessária a avaliação de diversos fatores que podem mascarar os efeitos endógenos dos ritmos de atividade, além da própria descrição do padrão de atividade de grupos de formigas em uma colônia.

\subsubsection{Características da trilha de forrageamento em diferentes fases do dia}

Alguns aspectos já bem descritos sobre as trilhas de forrageamento das saúvas são conhecidos por influenciar nos comportamentos das formigas. Mesmo em condições 
ambientais constantes e com alimentação à vontade, alguns outros fatores ainda desconhecidos modulam a atividade da trilha. A fim de eliminar possíveis influências externas e analisar com mais precisão os efeitos dos ritmos endógenos de atividade, se faz necessária a descrição dos padrões de fluxo de indivíduos na trilha; de transporte de fragmentos foliares e do tamanho dos indivíduos presentes na trilha nas diferentes fases do dia.

\subsubsection{Padrões coletivos de divisão de tarefas em turnos de trabalho}

Descrever como diferentes grupos de formigas distribuem suas atividades na trilha. Uma vez que existe a possibilidade de formigas apresentarem ritmos de atividade diferentes entre si, é interessante observar o padrão de atividade de grupos de formigas ao longo do tempo a fim de identificar se elas de fato dividem a tarefa de forrageamento ao longo do dia e como elas o fazem.

\subsubsection{Análise morfológica das formigas observadas em diferentes fases}

Analisar a diferença de tamanho corpóreo de formigas observadas em diferentes fases do dia. É possível que exista essa diferença morfológica porque as saúvas são altamente polimórficas e esse polimorfismo está associado à diversos aspectos da divisão de tarefas. Faz sentido, portanto, que o polimorfismo também guarde relação com a divisão temporal de tarefas.

\subsubsection{Análise da eficiência de forrageamento em diferentes fases}

Se de fato a colônia possui dois estados de atividade (alto durante a noite e baixo durante o dia) é possível que as relações internas da colônia também se apresentem em dois estados. Nesse caso, seria possível observar uma relação diferenciada de alguns mecanismos coletivos de manutenção da colônia. Tais alterações poderiam modificar a maneira com a qual a colônia responde a presença do alimento. Dessa forma, é válida a analise da eficiência na coleta de alimento em função da atividade. Mais especificamente a relação entre a quantidade de alimento coletado e o numero de formigas alocadas no forrageamento. 


\section{Materiais e métodos}

O experimento consistiu de duas etapas: (1) marcação (24h inicias) e filmagem para posterior análise (cinco dias). A marcação e filmagem foram realizadas em quatro turnos de duas horas nas fases de claro e escuro - padrões diferentes identificavam cada horário. As contagens e mensurações envolveram tanto as formigas que transportavam folhas da área de forrageamento para a colônia quanto àquelas que não transportavam, permitindo definir o fluxo das formigas, seus tamanhos e também seus turnos de trabalho ao longo de $24 \mathrm{~h}$.

\subsection{As formigas}

Para a realização dos experimentos, foram utilizadas seis colônias de Atta sexdens rubropilosa mantidas no biotério de animais ectotérmicos do Departamento de Fisiologia do Instituto de Biociências da Universidade de São Paulo (IB-USP). Todas as colônias tinham pelo menos três anos de idade. As colônias também possuíam um jardim de fungos de pelo menos três litros. Esses parâmetros de idade e de tamanho asseguram que as colônias utilizadas estavam na fase adulta e apresentam características compatíveis às colônias adultas em campo.

\subsection{Manutenção dos animais}

A umidade relativa do ar no biotério no qual elas eram mantidas era controlada e permanecia a $70 \%(+/-10 \%)$; a temperatura também era controlada em $23^{\circ} \mathrm{C}\left(+/-3^{\circ} \mathrm{C}\right)$. O fotoperíodo era mantido por luz artificial como o natural, tendo a sala janelas que permitiam a entrada de luz. No biotério as colônias eram alimentadas diariamente com folhas de Acalipha sp. recém coletadas, flocos de aveia e solução de sacarose. Tal composição alimentar fornece todos os nutrientes necessários para a manutenção e o desenvolvimento tanto dos indivíduos, quanto do fungo simbionte.

Em todas as colônias o fungo era criado pelas formigas em um pote cilíndrico de plástico cujo fundo foi removido e substituído por uma camada de gesso. Os potes eram mantidos em bandeja plástica em que as bordas da bandeja foram 'pintadas' com uma mistura de talco inodoro e álcool para impedir a fuga das formigas. O gesso previne o 
acumulo de líquidos devido ao excesso de agua precipitado nas paredes do pote plástico. O lixo acumulado (restos de folhas secas, hifas de fungo mortas, formigas mortas e dejetos) naturalmente pelas formigas em um dos cantos da bandeja era removido com frequência para evitar o acúmulo exacerbado de partículas potencialmente danosas.

\subsection{Arranjo experimental}

Ao longo de seis dias as formigas foram marcadas (dia 1) e filmadas (dia 2 ao 6) em horários definidos, para posterior avaliação de turno de atividade preferencial, alocação na tarefa de transporte de folhas, morfometria e definição de fluxo. Quatro intervalos de tempo (doravante turnos) ao longo das 24 horas foram selecionados para a marcação, realizada apenas no primeiro dia, e gravação da atividade na trilha, realizada ao longo dos cinco dias. Dois turnos foram na fase de claro (A - 10h00 às $12 \mathrm{~h} 00$ e B$14 \mathrm{~h} 00$ às $16 \mathrm{~h} 00)$ e dois na fase de escuro (C - 22h00 às 00h00 e D - 02 h00 às 04h00) Figura y. Note que o intervalo entre gravações na mesma fase foi de duas horas e o intervalo entre gravações entre fases diferentes foi de seis horas, evitando que as filmagens ocorressem perto da transição entre o claro e o escuro. Com esse protocolo de marcação e filmagem foi garantido dois eventos de gravação por condição de iluminação, o que permite verificar se existe alguma variação entre os diferentes turnos de uma mesma fase, ou se as características da fase permanecem as mesmas constantemente.

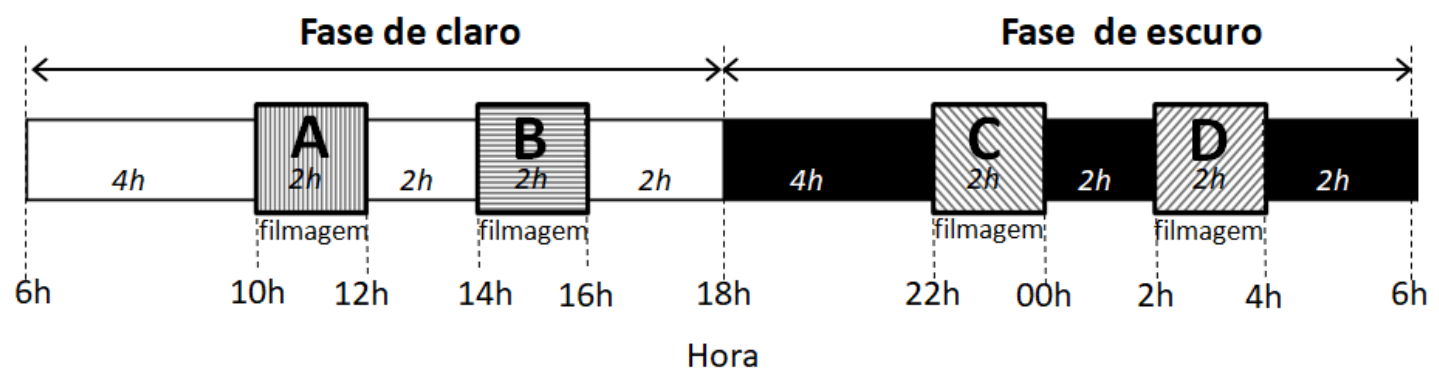

Figura 4: fases de gravação dos vídeos e representação dos diferentes grupos de formigas marcados. 


\subsection{Protocolo de filmagem}

Para que ocorresse a filmagem as formigas eram transferidas do biotério para a sala de experimento. À bandeja em que era mantida a colônia era ligada outro recipiente plástico através de uma ponte de madeira de 75 centímetros de comprimento, que será doravante denominada de trilha, conforme a figura $\mathrm{x}$. Neste novo recipiente era disponibilizado o alimento para a colônia. A alimentação durante os experimentos era composta exclusivamente de folhas de Acalipha sp. e permanecia disponível ad libitum.

As condições ambientais na sala de experimento eram controladas em um espectro mais restrito. A temperatura era mantida constante a $23^{\circ} \mathrm{C}\left(+/-1^{\circ} \mathrm{C}\right)$ e a umidade relativa do ar a $70 \%(+/-2 \%)$. O fotoperíodo também era controlado em 12 horas de claro por 12 horas de escuro (12:12 LD), com as luzes se acendendo as 06h00 e se apagando as $18 \mathrm{~h} 00$. Durante a fase de escuro uma lâmpada de LED vermelho (fora do espectro do visível para as formigas) foi mantida acesa.
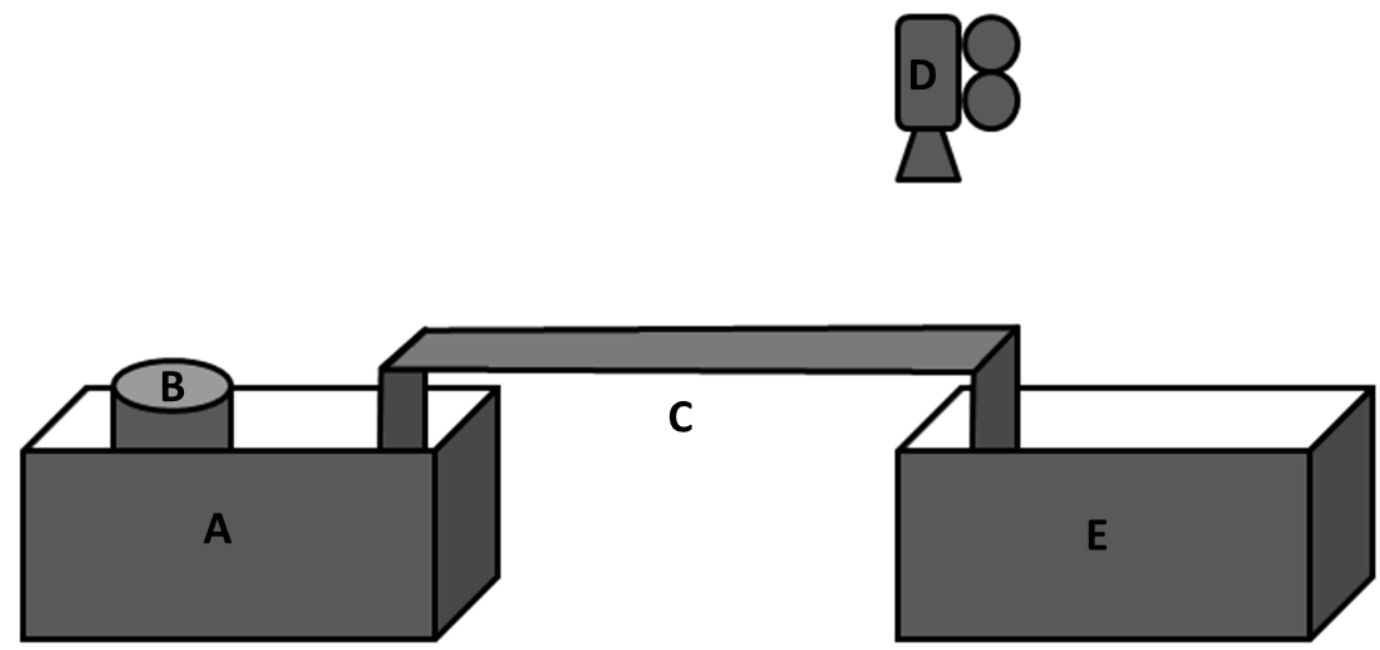

Figura 5: Esquema do arranjo espacial experimental. (A) área da colônia; (B); pote do jardim de fungo; (C) ponte de ligação; (D) área de forrageamento; (E) posicionamento da câmera de filmagem no final da trilha.

Todas as colônias permaneceram nestas novas condições ambientais em aclimatação por pelo menos 14 dias antes do início dos experimentos. Dessa forma, assegurou-se que efeitos de transição devido à alteração das condições ambientais não interferiram nos dados coletados.

Uma webcam (Microsoft® LifeCam) foi posicionada ao final da trilha, de forma que o campo de visão contemplasse a totalidade da largura da ponte. Um computador 
conectado a webcam foi mantido ligado durante toda a duração do experimento. $\mathrm{O}$ software de captura de imagens iSpy® foi utilizado para programar as diferentes fases de gravação dos vídeos que foram utilizados para as análises (ver figura Y). Os vídeos foram gravados e posteriormente analisados para verificação de uma série de parâmetros explicados na próxima seção.

\subsection{Protocolo de marcação e observação}

Para identificar se as formigas apresentam horário de atividade preferencial é necessário marcar alguns indivíduos e observar posteriormente em qual fase do dia eles retornam à atividade. Portanto, quatro grupos de formigas foram marcados em diferentes fases e turnos do dia. Os turnos de marcação coincidem com os turnos de gravação estabelecidos anteriormente, ou seja: das $10 \mathrm{~h} 00$ às $12 \mathrm{~h} 00$, das $14 \mathrm{~h} 00$ às $16 \mathrm{~h} 00$, das $22 \mathrm{~h} 00$ às $00 \mathrm{~h} 00$, e das $02 \mathrm{~h} 00$ às $04 \mathrm{~h} 00$.

Durante as duas horas de cada um dos turnos de marcação todas as formigas que passassem pela trilha carregando algum fragmento de folha eram coletadas e marcadas com uma caneta Sharpie® Oil-based de cor prateada. Logo após a marcação o indivíduo era devolvido à colônia. A cor prateada foi escolhida por permitir a visualização de formigas marcadas tanto durante o dia, com iluminação branca, quanto durante a noite, com iluminação vermelha. Foram selecionadas as formigas transportadoras, pois estas representam um subgrupo de tamanho adequado para as posteriores analises e porque, como elas estavam engajadas em uma tarefa, com certeza estavam em sua fase de atividade.

Os indivíduos pertencentes aos diferentes grupos de formigas marcadas (i.e. formigas que forrageavam em diferentes horários) eram identificados através de padrões de marcação nos diferentes segmentos do corpo. Formigas que transportavam folhas entre (A) $10 \mathrm{~h} 00$ e $12 \mathrm{~h} 00$ eram marcadas na cabeça e no abdômen; formigas que transportavam entre (B) 14h00 e $16 \mathrm{~h} 00$ eram marcadas na cabeça e no tórax; das (C) 22h00 às 00h00 as formigas recebiam marcação no tórax e no abdômen; e as formigas que apareciam das (D) $02 \mathrm{~h} 00$ às $04 \mathrm{~h} 00$ eram marcadas na cabeça, tórax e abdômen (figura z). Posteriormente era contabilizado o número de vezes que essas formigas marcadas eram avistadas nos diferentes turnos do dia ao longo dos 5 dias de experimento. 


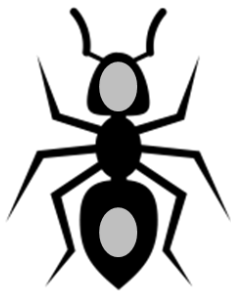

A

$10 \mathrm{~h} 00-12 \mathrm{~h} 00$

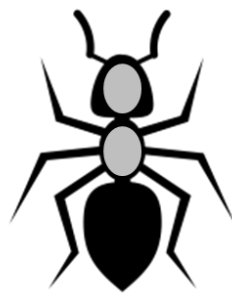

B

$14 \mathrm{~h} 00-16 \mathrm{~h} 00$

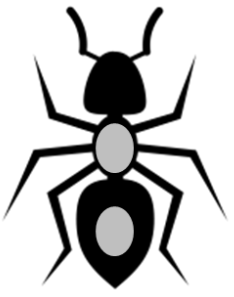

C

$22 \mathrm{~h} 00-00 \mathrm{~h} 00$

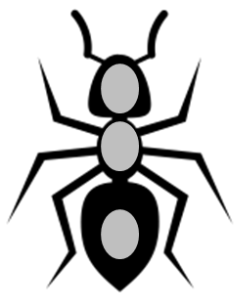

D

02h00-04h00

Figura 6: Padrões de marcação feita nas formigas transportadoras que transportavam nas diferentes fases.

\subsection{Análise dos vídeos e contagem das formigas}

Ao final do primeiro dia de experimento, quando todas as formigas pertencentes aos quatro turnos de gravação estavam marcadas, iniciava-se o processo de filmagem para posterior observação e contabilização. Durante os cinco dias seguintes à marcação, todas as formigas marcadas que transitavam pela trilha nos quatro turnos de gravação, carregando ou não folhas, eram contabilizadas e categorizadas de acordo com o tipo de marcação. Também eram contabilizadas as formigas não marcadas que eventualmente eram identificadas carregando folhas. Algumas formigas transportadoras não puderam ser identificadas, porque os fragmentos de folha que elas transportavam cobriam a totalidade do corpo delas impedindo a visualização do padrão de marcação ou a ausência deste. Esses eventos de transporte de folha por formigas cuja identificação não foi possível também foram contabilizados. Esses dados foram coletados para todos os cinco dias de gravação do experimento. Dessa forma, obteve-se o número total de formigas marcadas que transitaram nas diferentes fases de gravação e o número total de eventos de transporte de folhas, por formigas marcadas ou não.

Outro dado coletado diz respeito ao fluxo de formigas na trilha nas diferentes fases e turnos do dia. Para obter essa medida os vídeos de 2 horas gravados para cada turno foram divididos em 12 trechos de 10 minutos. Para cada um desses trechos 1 minuto era selecionado de forma aleatória para a contabilização de todas as formigas que transitassem pela trilha. Dessa forma, obteve-se uma estimativa do número de formigas que transitou naqueles 10 minutos e gerada a estimativa do número de formigas total que transitou na trilha em cada um dos turnos ao longo dos cinco dias de experimento. 
Portanto, as variáveis contabilizadas com esse protocolo são: (1) formigas marcadas que transitaram pela trilha nos diferentes turnos de gravação; (2) formigas marcadas que transportaram folhas; (3) formigas não marcadas; (3) fluxo total de formigas pela trilha; (4) total dos eventos de transporte de folhas pela trilha.

O fluxo de formigas na trilha é um aspecto inerente e multifatorial que precisa ser analisado para aumentar a precisão da interpretação dos resultados. Isso porque o fluxo na trilha é o resultado observável de diversos mecanismos de comunicação e controle que convergem a esse padrão comportamental coletivo. Portanto, foi feita a avaliação da variação do fluxo de formigas na trilha nas diferentes fases e turnos do dia. Esses dados permitiram verificar qual é o ritmo de atividade coletivo das colônias.

A fim de identificar se formigas mantém um turno preferencial de atividade, diversas análises foram feitas. Analisou-se se a variação do número de formigas marcadas em cada turno ao longo dos dias para identificar se os indivíduos permaneciam ativos no mesmo turno ou se eles migravam para outro turno. Analisou-se também a preferencia global de fase de atividade das formigas marcadas, ou seja, em qual fase (claro ou escuro) os grupos de formiga eram mais ativos.

Outro grupo de análises diz respeito exclusivamente às formigas marcadas que foram observadas realizando a tarefa de transporte de folha. Para esse grupo mais restrito de formigas analisou-se igualmente a distribuição diária nos diferentes turnos e a preferencia global da fase de engajamento na tarefa de transporte.

Considerando-se a possibilidade de que a maior diferença nas medidas coletadas ocorra de maneira menos restrita ao horário, foi feito o agrupamento das formigas marcadas A e B como formigas de claro; e das formigas marcadas C e D como formigas de escuro. Dessa forma, desconsideraram-se os aspectos de variação que pudessem existir em diferentes turnos de uma mesma condição de iluminação.

Por fim, analisou-se a relação entre o transporte de folhas e fluxo total na trilha. Com essa medida, foi possível discutir aspectos de eficiência de forrageamento nas diferentes fases de observação. 


\subsection{Análise de morfometria}

Uma característica que pareceu relevante durante as observações dos vídeos foi o tamanho das formigas que percorriam as trilhas nas diferentes fases. As observações pareciam indicar que as formigas que transitavam em claro eram maiores que as formigas que transitavam em escuro. Decidiu-se então testar se de fato essa diferença aparente era real.

O método utilizado para medir as formigas foi indireto, ou seja, as formigas foram medidas em vídeo. Para isso, foi utilizado o software de análise de imagens ImageJ®. Com esse software é possível medir em pixels o comprimento, área, cor e diversos outros parâmetros de imagem. Esse software permite também a transformação da medida obtida em pixels em unidades de medidas do sistema métrico. Portanto, foi possível a obtenção do tamanho das formigas em centímetros.

Frames aleatórios dos vídeos gravados nas replicas 5 e 6 foram obtidos. Utilizaram-se apenas essas replicas, pois nos vídeos obtidos foi possível obter um valor de referência para utilizar na transformação dos valores em pixels para centímetros. Esse valor de referência diz respeito a uma marcação de $4 \mathrm{~cm}$ feita posteriormente no trecho da ponte que liga a colônia à bandeja de forrageamento.

Os frames aleatórios foram obtidos dividindo-se as duas horas de cada fase de observação em 7200 segundos. Depois, utilizando-se do software de aleatorização disponível em www.random.org, foram selecionados 400 frames distribuídos em todas as fases de observação das duas réplicas analisadas. Em outras palavras, 10 frames por vídeo.

Nos frames selecionados todas as formigas foram medidas utilizando a ferramenta de medir comprimento do software ImageJ $®$. As medidas obtidas em pixels foram transformadas em centímetros utilizando o valor de referência presente na ponte. O comprimento medido das formigas foi definido como uma linha que ligasse a ponta da mandíbula ao final do abdômen.

Ao final das medições obteve-se o valor do comprimento das formigas (em centímetros) que estavam na trilha nas 4 fases de observação ao longo dos 5 dias de experimento das réplicas 5 e 6 . Com esses dados foi possível fazer a análise do tamanho das formigas nas diferentes fases e nas diferentes condições de iluminação. 


\subsection{Análise estatística}

Os dados coletados dizem respeito ao numero de formigas observadas (variável quantitativa) e seus tamanhos (variável quantitativa) em diferentes categorias de observação referentes aos turnos (A, B, C e D), fases (claro e escuro) e dias (variável qualitativa).

Para as análises que envolviam avaliações dos efeitos de reamostragem das variáveis quantitativas nas categorias de: (1) turno de observação ou (2) dias do experimento, foi adotada a análise de variância (ANOVA). Quando constatado que as distribuições pertenciam a grupos de formigas diferentes foi feito o teste post hoc de Tukey para verificar quais conjuntos eram diferentes entre si.

No caso da reamostragem na categoria de fase (i. e. claro ou escuro) foi realizado o teste $\mathrm{T}$ para comparação das distribuições observadas.

Para a observação dos efeitos do fluxo na trilha no transporte de folhas foi adotada uma análise de regressão linear múltipla seguida de uma análise de variância, sendo as variáveis o número de formigas transportadoras e o fluxo total. Neste caso, está se analisando dois conjuntos de variáveis quantitativas em uma categoria qualitativa discreta (dia e/ou fase de observação). Neste tipo de análise correlaciona-se duas variáveis quantitativas que podem ser subdividas em uma ou mais categorias. Observa-se posteriormente se a regressão dos dados nessas diferentes categorias constroem correlações diferentes entre si.

Para a análise do tamanho das formigas foi comparada a distribuição do tamanho das formigas observadas nos 4 diferentes turnos de observação através de uma análise de variância (ANOVA). Posteriormente, foi realizado um teste post hoc de Tukey para verificar quais grupos eram diferentes entre si.

Todas as análises estatísticas foram realizadas utilizando-se o software $\mathrm{R} \circledR$ versão 3.3.1 associado ao pacote de interface gráfica do R Studio®. Os gráficos apresentados foram feitos ou no próprio R ou no programa Microsoft Office Excel ${ }^{\mathrm{TM}}{ }^{\circledR}$. 


\section{Resultados}

Entre as seis réplicas do experimento foram marcadas 673 formigas. No total foram gravadas e analisadas 240 horas de vídeos. Nessas gravações foi contabilizado o trânsito de 289.260 formigas das quais 14.075 estavam marcadas nos diferentes grupos (A, B, C e D). Foi observado também um total de 7.854 eventos de transporte de folha. As análises a seguir buscam identificar os padrões temporais de distribuição desses eventos nas diferentes fases (claro e escuro), turnos de observação (A, B, C e D) e ao longo dos 5 dias de observação. Os gráficos e análises mais relevantes e que melhor descrevem os fenômenos aqui estudados encontram-se nesta seção. Outros gráficos e análises contendo as distribuições de todos os dados entre as diferentes categorias analisadas poderão ser consultados no material suplementar.

\subsection{Análise do fluxo total de formigas na trilha}

\subsubsection{Fluxo total de formigas nas fases de claro e escuro}

Analisando-se da maneira mais categórica possível o fluxo na condição de iluminação de claro e de escuro (somando-se os valores de formigas totais observadas de $\mathrm{A}$ com $\mathrm{B}$ e de $\mathrm{C}$ com $\mathrm{D}$ ) nota-se que a maior atividade coletiva das formigas se dá na fase de escuro (figura 7). Sendo que o fluxo noturno é, em média, o dobro do fluxo diurno (média do fluxo noturno $=3771$; média do fluxo diurno $=1658$ ), como mostra o teste $\mathrm{T}\left(\mathrm{t}_{(107,86)}=3,456, \mathrm{p}<0,001\right)$.

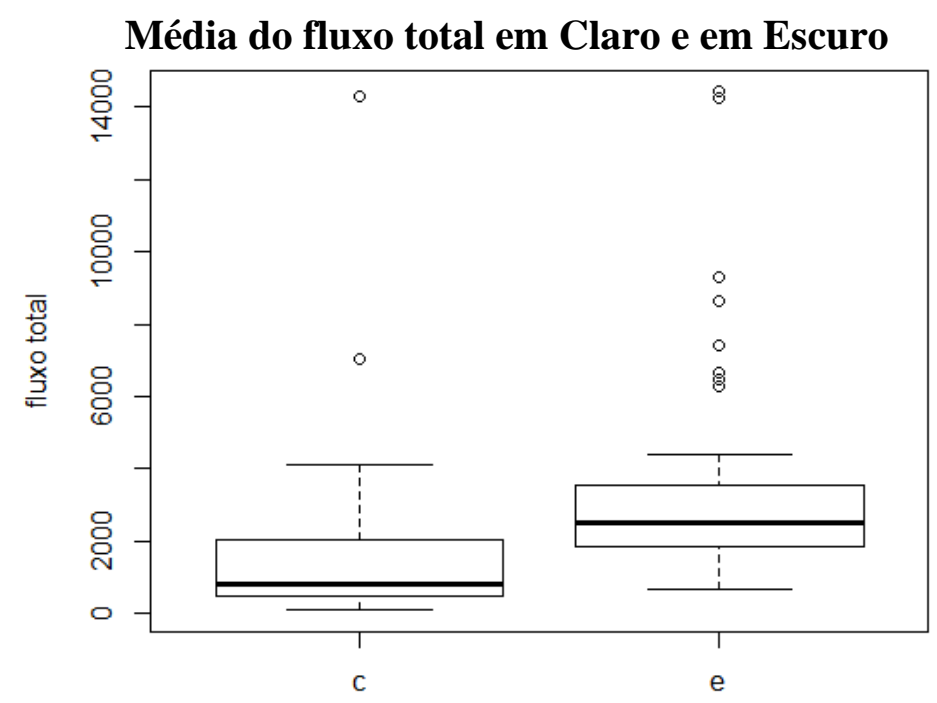

Figura 7: média do fluxo total em claro e em escuro. O fluxo total no escuro é o dobro e significativamente maior do que no claro. (c=claro; e=escuro). 


\subsubsection{Fluxo nos turnos de marcação}

A metodologia adotada permite a análise do fluxo total em turnos dentro de uma mesma fase. Portanto, o fluxo total diurno e noturno foi subdividido nos turnos A, B, C e D. A contabilização do fluxo total de formigas na trilha nesses diferentes turnos de observação indica claramente que o pico de atividade coletiva das formigas é entre as $22 \mathrm{~h} 00$ e $00 \mathrm{~h} 00$ (turno $\mathrm{C}$ ), com pode se observar na figura 8. É possível observar também que entre às $02 \mathrm{~h} 00$ e às $04 \mathrm{~h} 00 \mathrm{a}$ atividade na trilha é representada em um valor intermediário entre o pico de atividade noturno e a atividade menor durante o dia. Esses valores são corroborados por uma análise de variância $\left(f_{(3,114)}=5,613, p=0,001\right)$ e pelo pós-teste de Tukey.

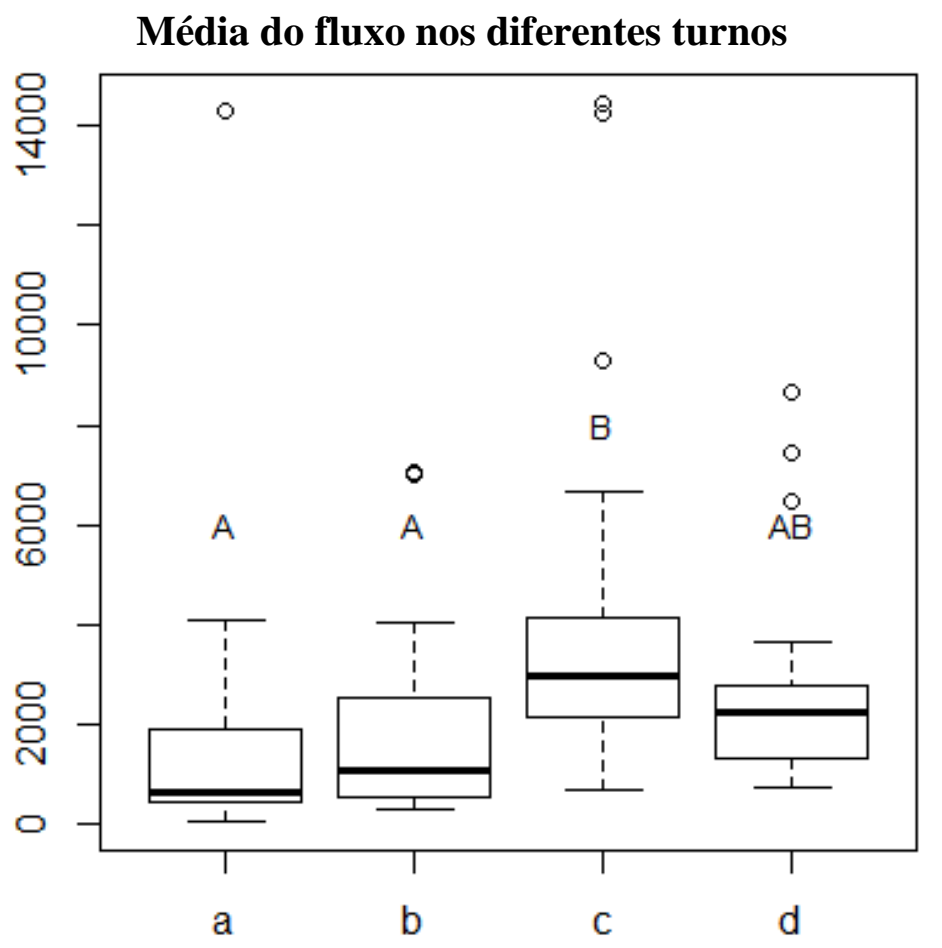

Figura 8: média do fluxo observado nas diferentes fases de análise. a- $10 \mathrm{~h} 00$ às $12 \mathrm{~h} 00$, b- $14 \mathrm{~h} 00$ às $16 \mathrm{~h} 00, \mathrm{c}-22 \mathrm{~h} 00$ às $00 \mathrm{~h} 00, \mathrm{~d}-02 \mathrm{~h} 00$ às 04h00, ANOVA: $\mathrm{f}_{(3,114)}=5,613$, $\mathrm{p}=0,001$. Os códigos acima dos boxplots representam os valores significativamente diferentes pelo teste post hoc de Tukey.

\subsubsection{Fluxo ao longo dos cinco dias de experimento}

A metodologia também permite a análise do fluxo total na trilha ao longo dos cinco dias de experimento. As análises estatísticas indicam que o fluxo na trilha 
permanece constante (two-way ANOVA: $\mathrm{f}_{\mathrm{dia}}=1.255, \mathrm{p}_{\mathrm{dia}}=0,292, \mathrm{f}_{\text {fase }}=5.517, \mathrm{p}_{\text {fase }}=0,001$, $\mathrm{df}_{4,3,110}$ ) - Figura 9. O que de fato nota-se é que, mesmo ao longo dos dias, a fase $\mathrm{C}$ é a que apresenta consistentemente maior fluxo; com as fases A e B, que estão em condição de iluminação em claro com o menor fluxo e a fase D em um valor intermediário entre os dois extremos.

\section{Fluxo total ao longo dos 5 dias}
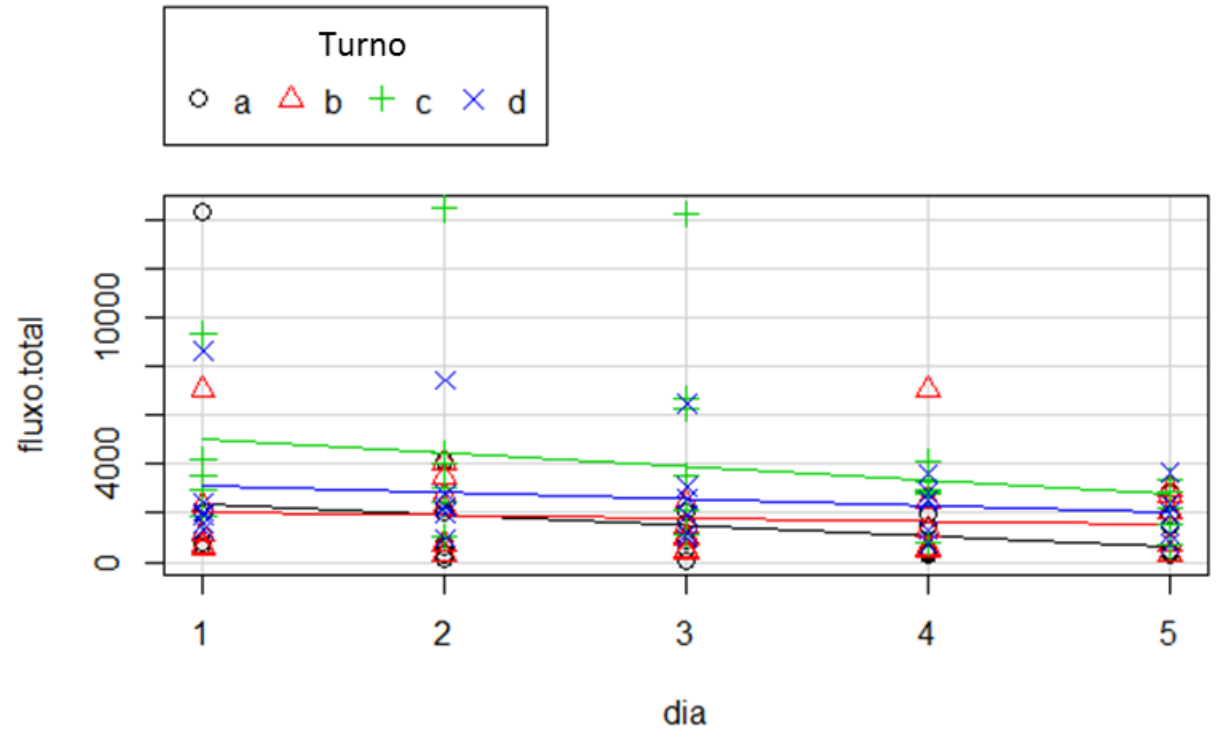

Figura 9: distribuição do fluxo total nos diferentes turnos de observação ao longo dos 5 dias. Two-Way ANOVA: $\mathrm{f}_{\mathrm{dia}}=1.255, \mathrm{p}_{\mathrm{dia}}=0,292, \mathrm{f}_{\text {fase }}=5.517, \mathrm{p}_{\text {fase }}=0,001, \mathrm{df}_{4,3}, 110$,

\subsection{Fluxo de formigas marcadas}

A análise para identificar se as formigas permanecem ativas em uma mesma fase consiste em analisar dois parâmetros. É necessário descrever a fase preferencial de atividade e se essa fase preferencial permanece a mesma ao longo do dia. Caso as formigas não permaneçam ativas na mesma fase ao longo do dia, é interessante tentar identificar para qual outra fase elas migram. Portanto, as análises devem ser feitas sobre a fase preferencial de atividade e manutenção da atividade em uma mesma fase ao longo dos dias.

Vale ressaltar que existem quatro grupos de formigas que foram observados. Esses 4 grupos são independentes entre si, ou seja, não há formigas que pertencem a 
mais de um grupo ao mesmo tempo. As análises foram feitas observando-se a atividade (i.e. quantas formigas foram observadas na trilha) de um determinado grupo de formiga marcadas nos diferentes turnos ao longo dos dias.

\subsubsection{Fluxo de formigas marcadas nas fases de claro e escuro}

Uma das possibilidades de análise derivada da metodologia utilizada é agrupar as formigas marcadas nos quatro diferentes turnos em formigas de claro e formigas de escuro. $\mathrm{O}$ mesmo vale para a distribuição dessas formigas durante o dia e durante a noite. A figura 10 mostra qual é a média de formigas de claro nas fases de claro e escuro e a média de formigas de escuro nas fases de claro e escuro. Nota-se que existe uma preferência das formigas por permanecer na mesma fase em que foram marcadas. $\mathrm{Ou}$ seja, formigas de claro aparecem mais na de dia e formigas de escuro aparecem mais de noite. Como o grupo de formigas de claro é independente do grupo de formigas de escuro, foi realizado um teste $\mathrm{T}$ comparando a média de formigas desses dois grupos nas duas diferentes fases. Em ambos os casos o teste $\mathrm{T}$ indica uma diferença significativa entre as médias em claro e escuro, tanto para formigas de claro como para formigas de escuro. Sendo que a média é maior sempre na mesma fase em que o grupo de formigas foi marcado.

\section{Contagem de formigas marcadas observadas durante o dia e durante a noite (média e erro padrão)}

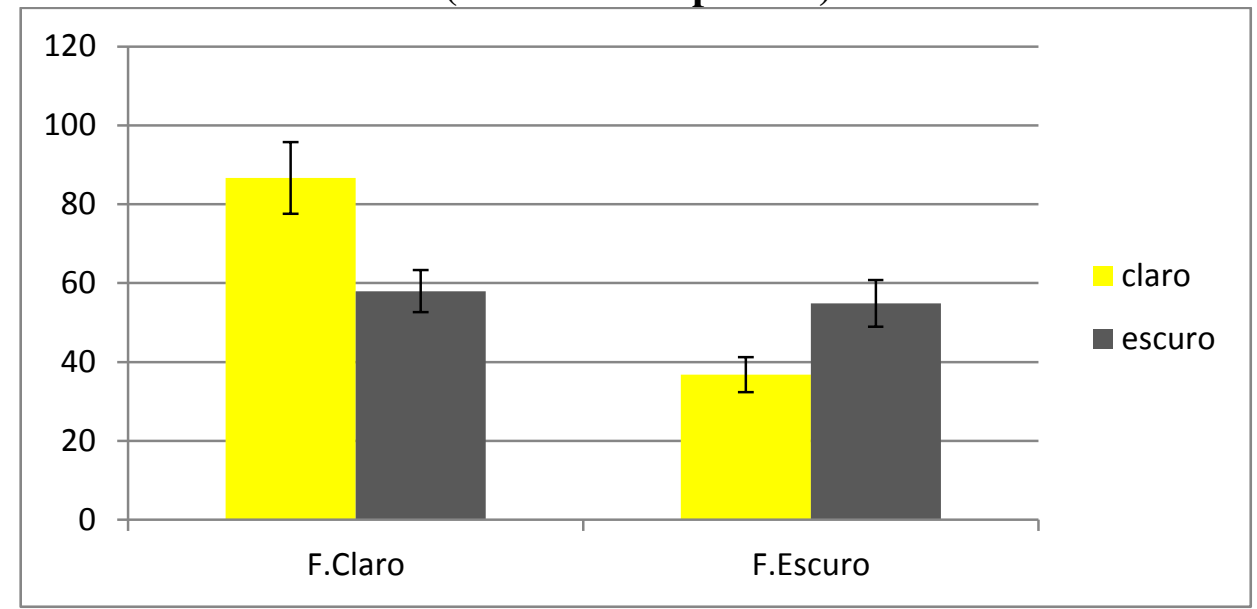

Figura 10: média de formigas marcadas em claro e em escuro observadas nas fases de claro e escuro. As barras indicam o erro padrão associado às médias apresentadas. Teste $\mathrm{t}$ para formigas de claro: $\mathrm{t}_{(46,937)}=2.921, \mathrm{p}=0,005$. Teste $\mathrm{t}$ para formigas de escuro: $\mathrm{t}_{(52,327)}=-2.438, \mathrm{p}=0,018$. 


\subsubsection{Fluxo de formigas marcadas nos turnos de observação}

Apesar do resultado muito claro acerca da preferência de fase de atividade por formigas marcadas em claro e em escuro, é válida a análise da distribuição dessas formigas em seus respectivos turnos dentro de uma mesma fase. Inclusive porque, como foi mostrado na figura 8 , existe diferença no fluxo entre os diferentes turnos de uma mesma condição de iluminação. A figura 11 mostra qual é a média de formigas marcadas em A, B, C e D nos diferentes turnos de observação.

Média de formigas A, B, C e D observadas nos diferentes turnos

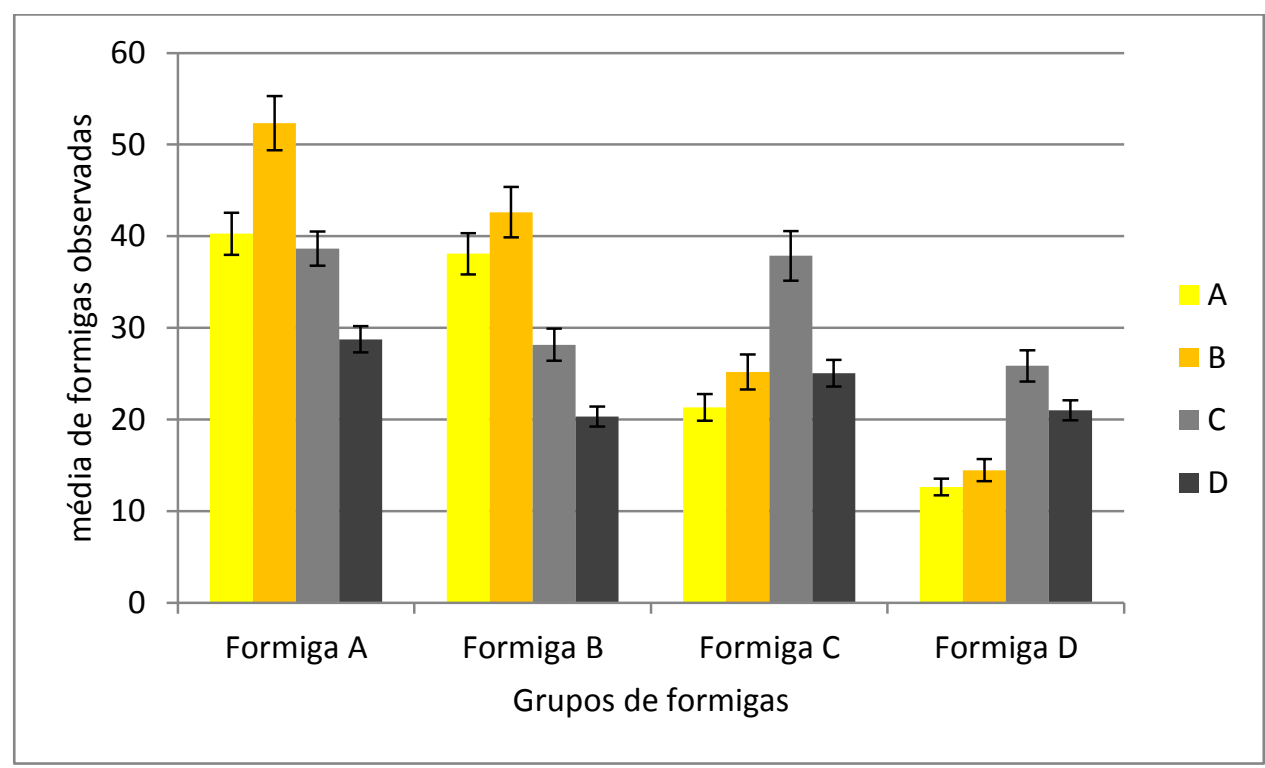

Figura 11: média de formigas marcadas em A, B, C e D observadas nos posteriores turnos A, B, C e D. Os turnos A e B ocorrem na fase de claro, enquanto os turnos C e $\mathrm{D}$ ocorrem na fase de escuro. Essas condições são representadas pela cor da barra: tons de amarelo indicam fases de claro e tons de cinza indicam fase de escuro. As linhas indicam o erro padrão associado à média.

Formigas que foram marcadas no turno A (10h00-12h00) apresentam preferencia de atividade pelo turno B (14h00-16h00), como mostra a figura 12. Fica claro também que essas formigas aparecem com pouca frequência entre $02 \mathrm{~h} 00$ e $04 \mathrm{~h} 00$ (fase D). Nas fases A e C os valores são intermediários (ANOVA: $\mathrm{f}_{(3,114)}=4,7 ; \mathrm{p}=0,003$ ). Quando a análise é feita adicionando-se os dias como um fator em uma análise de variância de duas vias, nota-se que a frequência das observações não muda entre os dias. 
Entretanto, o fato de elas aparecerem com mais frequência na fase B é corroborado nessa análise de Two-Way ANOVA (material suplementar 1).

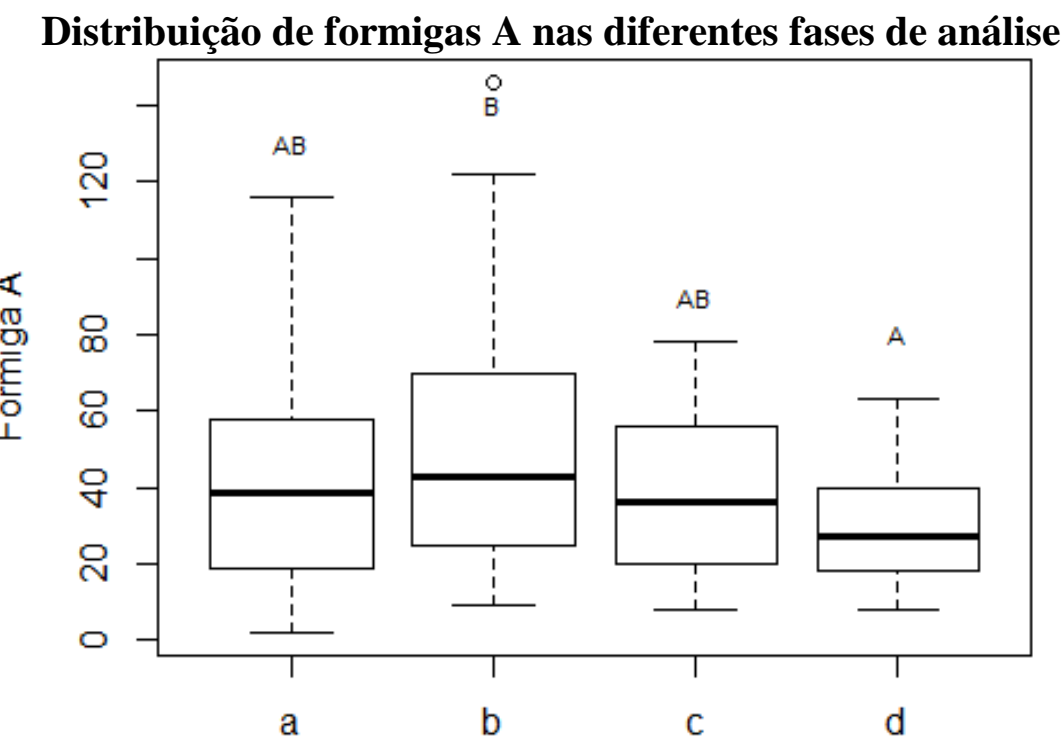

Figura 12: distribuição de formigas A (10h00-12h00) entre as fases de observação. ANOVA: $\mathrm{f}=4.7, \mathrm{df}_{3,114} ; \mathrm{p}=0,003$.

Já as formigas marcadas em B apresentam claramente atividade preferencial no mesmo turno em que foram marcadas (figura 13; ANOVA: $f_{(3,114)}=7.568 ; p=0,0001$ ), como observado na figura 13. De maneira semelhante às formigas A, não há variação na frequência de formigas observadas nos turnos ao longo dos 5 dias. Todavia, a ANOVA de duas vias analisando o fluxo de formigas B pelos turnos e dias corrobora que existe preferência da atividade pelo turno B com turnos A e C sendo intermediários ao valor da atividade no turno D (material suplementar 2).

A análise da preferência por fase de atividade de formigas marcadas em $\mathrm{C}$ (22h00 às 00h00) indica que esse grupo de formigas é mais ativo no turno em que foi marcado e menos ativo no turno A (figura 14). Os valores de atividade observados para os turnos B e D são intermediários aos valores de A e C. A ANOVA de duas indica que essa distribuição global é consistente ao longo dos cinco dias de experimento e que não há variação de fluxo no tempo (material suplementar 3).

As formigas marcadas em D são mais ativas no turno $\mathrm{C}$, como é possível observar na figura 15. Esse grupo de formigas é menos ativo nos turnos A e B. A atividade no turno D assume um valor intermediário entre $[\mathrm{AB}]$ e C. Assim como nos 
grupos anteriormente analisados, a atividade das formigas D não varia ao longo dos 5 dias. Mas a ANOVA de duas vias para a distribuição de formigas D por dia e turno indica que elas são significativamente mais ativas na fase noturna do que nas fases diurnas. Nesse caso, a ANOVA de duas vias indica um resultado ligeiramente diferente da ANOVA de uma via para a preferencia global (material suplementar 4)

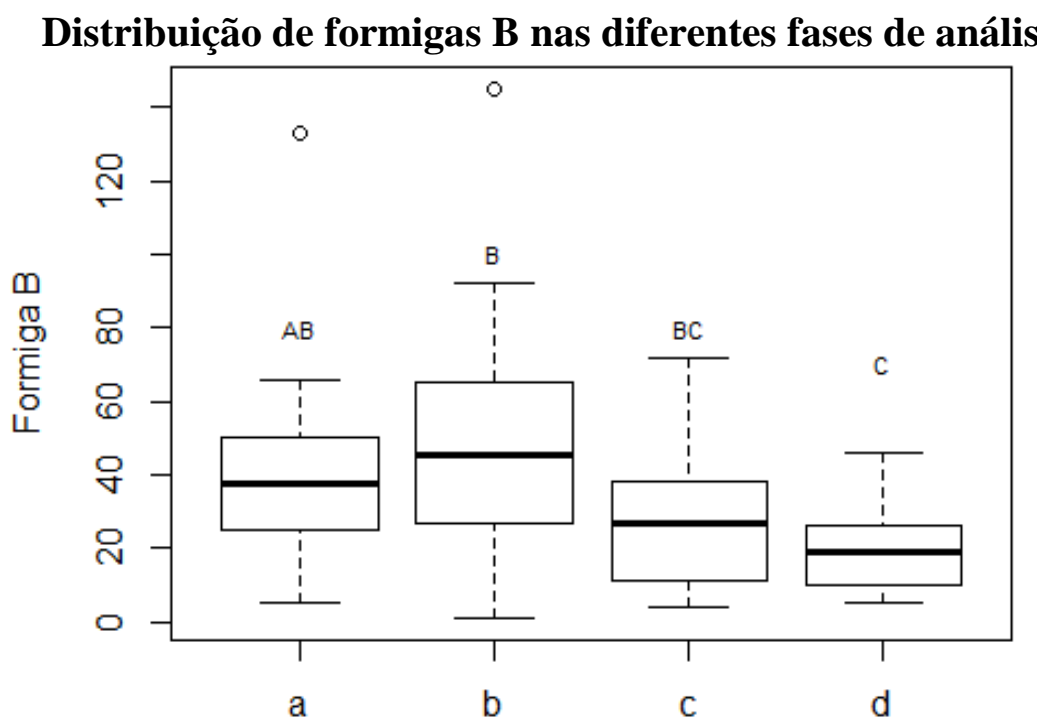

Figura 13: distribuição de formigas B (14h00-16h00) entre as fases de observação. ANOVA: $\mathrm{f}=7.568, \mathrm{df}_{3,114} ; \mathrm{p}=0,0001$

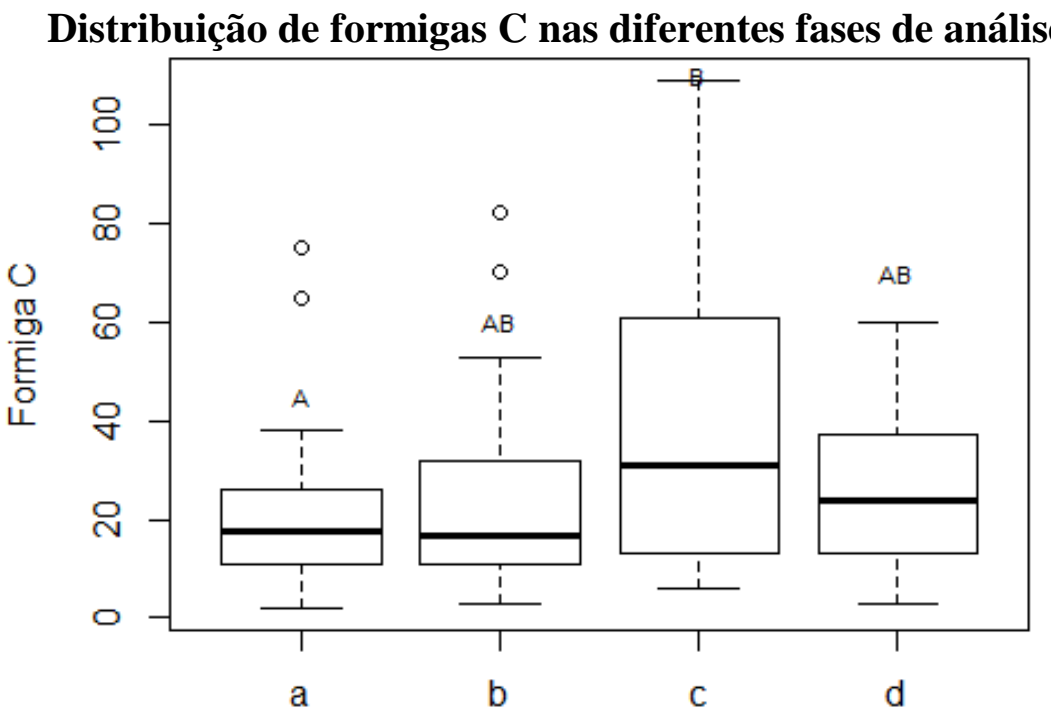

Figura 14: distribuição de formigas A (22h00-00h00) entre os turnos de observação. ANOVA: $\mathrm{f}=3,361 ; \mathrm{df}_{3,114} ; \mathrm{p}=0,021$. 
Vale ressaltar que os dias não constituem um fator significante para a análise de variância de duas vias. Portanto, as figuras 12, 13, 14, 15 mostram apenas o fator que explica algum tipo de variação na análise, ou seja, os turnos. Entretanto, as distribuições temporais,por turno e por dia encontram-se disponíveis no material suplementar.

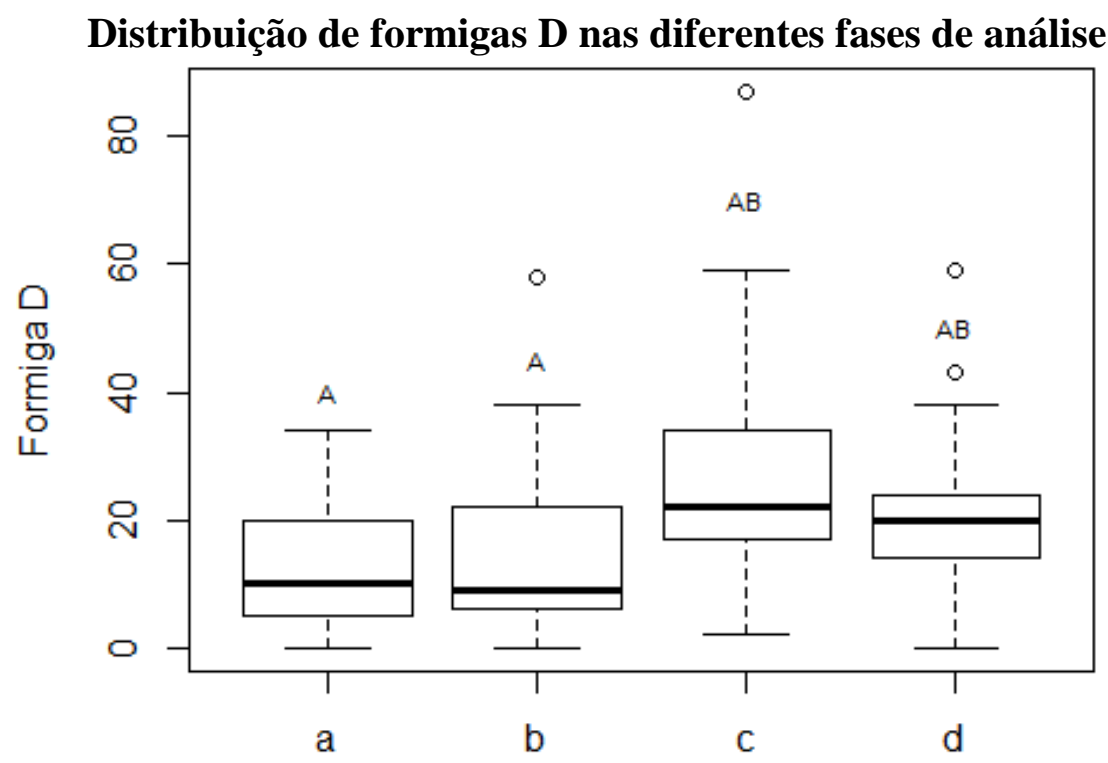

Figura 15: distribuição de formigas $\mathrm{C}(02 \mathrm{~h} 00-04 \mathrm{~h} 00)$ entre os turnos de observação. ANOVA: $\mathrm{f}=5,699 ; \mathrm{df}_{3,114} ; \mathrm{p}=0,001$.

\subsection{Análise do transporte total de folhas}

$\mathrm{Na}$ metodologia estabelecida apenas as formigas que estivessem transportando folhas foram marcadas, no entanto, durante as observações subsequentes estas seriam contadas mesmo que estivessem sem folhas. De fato, conforme mostram os resultados da seção anterior, existe atividade preferencial dessas formigas marcadas pelas suas determinadas fases, sem que essa preferência mude ao longo dos cinco dias analisados. Entretanto, essa análise refere-se à atividade preferencial independente do engajamento dessas formigas em qualquer tarefa especifica durante as observações.

\subsubsection{Distribuição do transporte total de folhas ao longo dos dias}

As análises a seguir são mais restritas no sentido de avaliar o engajamento preferencial nas diferentes fases do dia à tarefa de transporte de folha. Em outras 
palavras, visa analisar a fidelidade dessas formigas marcadas à tarefa na qual elas foram originalmente discriminadas. De forma semelhante aos resultados apresentados na seção anterior, nesta seção será explicitada a distribuição de formigas marcadas alocadas na tarefa de transporte de folhas nas diferentes fases do dia. Para alguns grupos os dias também constituíram um fator significante nas análises de variância de duas vias. Para esses grupos serão apresentados as distribuições de formigas marcadas ao longo dos 5 dias separados para os 4 turnos, além dos boxplots, como foi apresentado na seção anterior.

Vale ressaltar que foram observados todos os eventos de transporte, sendo eles realizados por formigas marcadas ou não. Dessa forma, é possível analisar a variação do transporte de folhas nas diferentes fases e turnos e ao longo dos 5 dias de experimento. Na figura 16 ressalta-se que o transporte de folhas permaneceu constante ao longo dos 5 dias.

\section{Transporte de folhas ao longo dos dias}

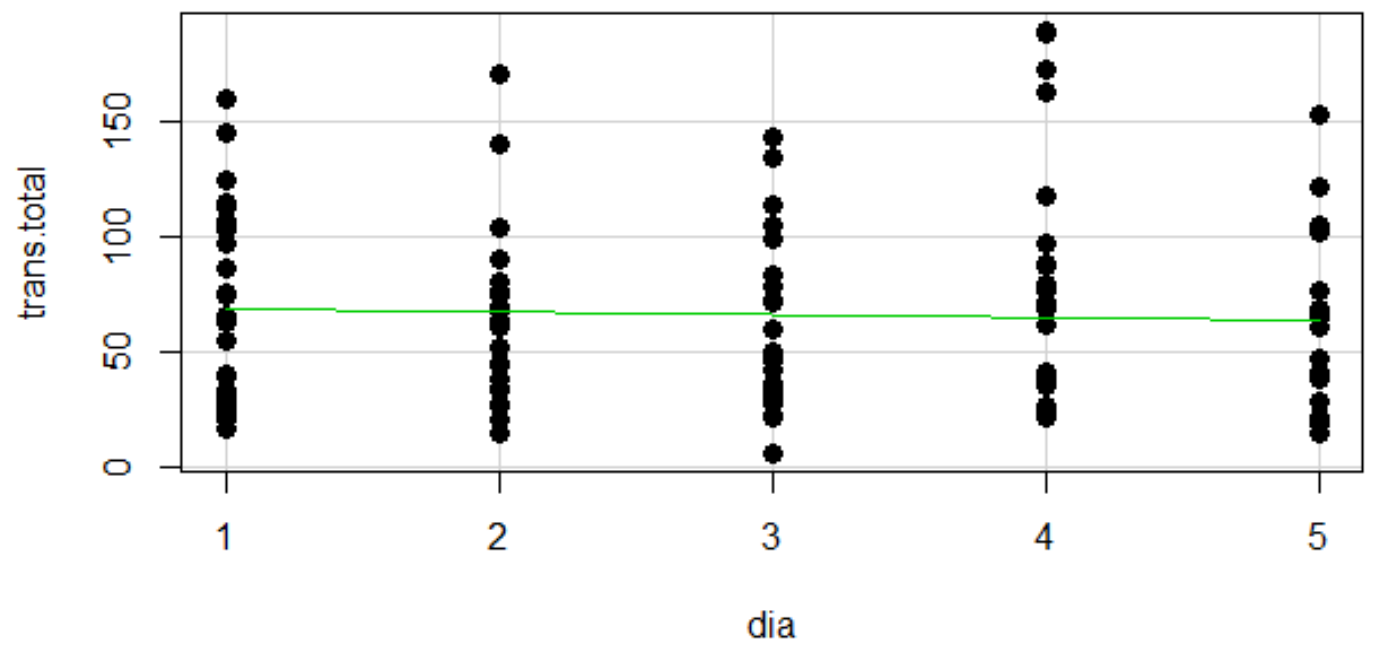

Figura 16: distribuição do transporte total de folhas ao longo dos 5 dias de experimento. ANOVA: $\mathrm{f}=0,21, \mathrm{df}_{1,116} ; \mathrm{p}=0,647$

O primeiro fato observável retirado dos dados é que o transporte de folhas ocorre com maior frequência nas fases de escuro, como se pode observar na figura 17. Entretanto, a média de transporte na fase escura não é o dobro da média observada na fase de claro, como seria esperado se o transporte estivesse diretamente correlacionado ao fluxo. 
Média do total de transporte de folhas nas fases de claro e escuro

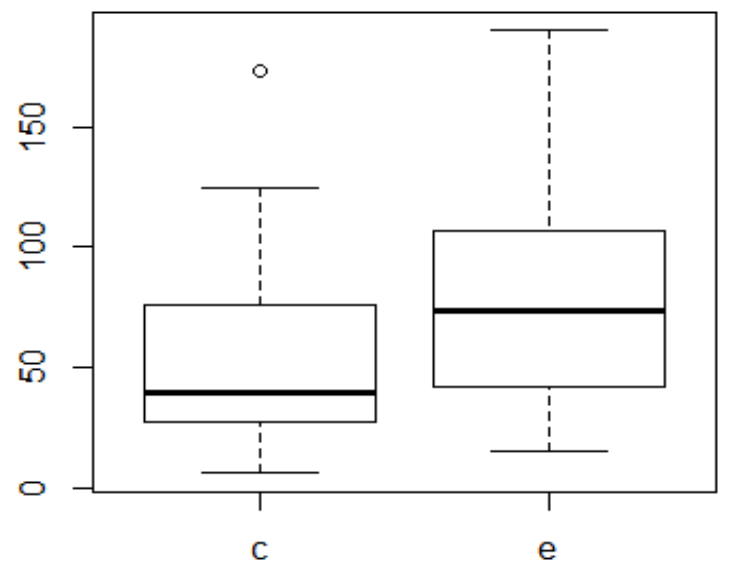

Figura 17: boxplots da distribuição do total de eventos de transporte de folha em claro e em escuro. Teste t: $(102,22)=-4.325, \mathrm{p}<0,0001$. Médias: claro $=51$; escuro=82.

\subsubsection{Distribuição do transporte total nos quatro turnos de marcação}

O transporte de folhas, diferentemente da atividade geral, acontece com maior frequência nas fases $\mathrm{C}$ e D. A menor frequência é observada na fase A e a fase B apresenta um valor intermediário entre [CD] e A (figura 18).

Distribuição dos eventos de transporte de folhas pelas 4 fases

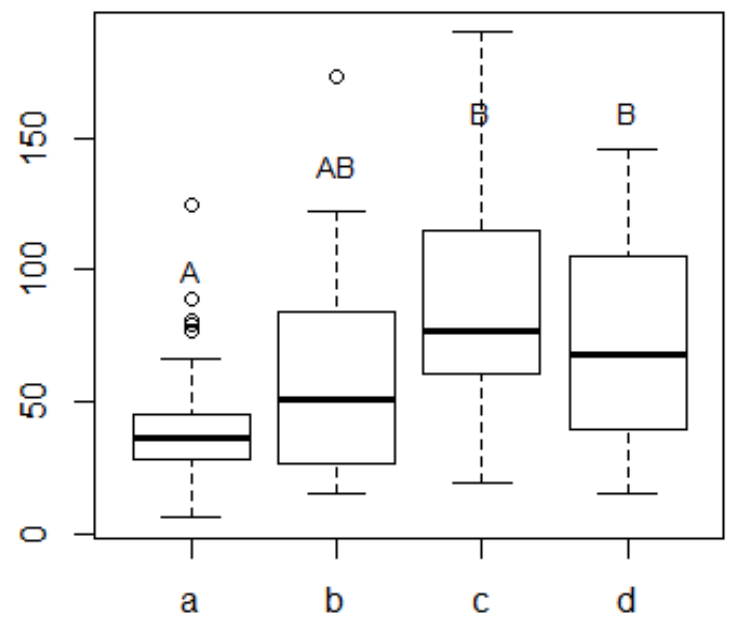

Figura 18: boxplots das distribuições dos eventos de transporte de folhas nos 4 turnos de análise, independente da marcação dos grupos. ANOVA: $f_{(3,114)}=8.969 ; p<0,001$. As letras iguais acima dos boxplots representam valores significativamente semelhantes dados em uma análise post hoc de Tukey. 


\subsection{Distribuição do transporte por formigas marcadas}

Nota-se que as formigas A que voltaram a transportar apresentam um padrão diferente daquele identificado na atividade geral. Formigas desse grupo tiveram redução significativa no engajamento ao transporte de folhas a partir do terceiro dia de análise, como mostra a ANOVA de duas vias e o material suplementar 5. Entretanto, mesmo quando elas estavam engajadas, o transporte de folha foi superior na fase B e menor nas fases C e D. A fase A se apresenta em um valor intermediário aos dois extremos (figura 19).

Formigas B voltaram a transportar ao longo de todos os dias e em todas as fases com exceção do dia 3. Nesse dia elas, por algum motivo transportaram significativamente menos. Vale ressaltar que a maior frequência de transporte foi na fase $\mathrm{B}$, ou seja, na mesma fase em que elas foram discriminadas, como mostra a figura 20. Nas fases C e D o transporte foi significativamente inferior ao observado em B; e a fase A apresenta um valor intermediário de transporte de folhas entre as duas distribuições (material suplementar 6).

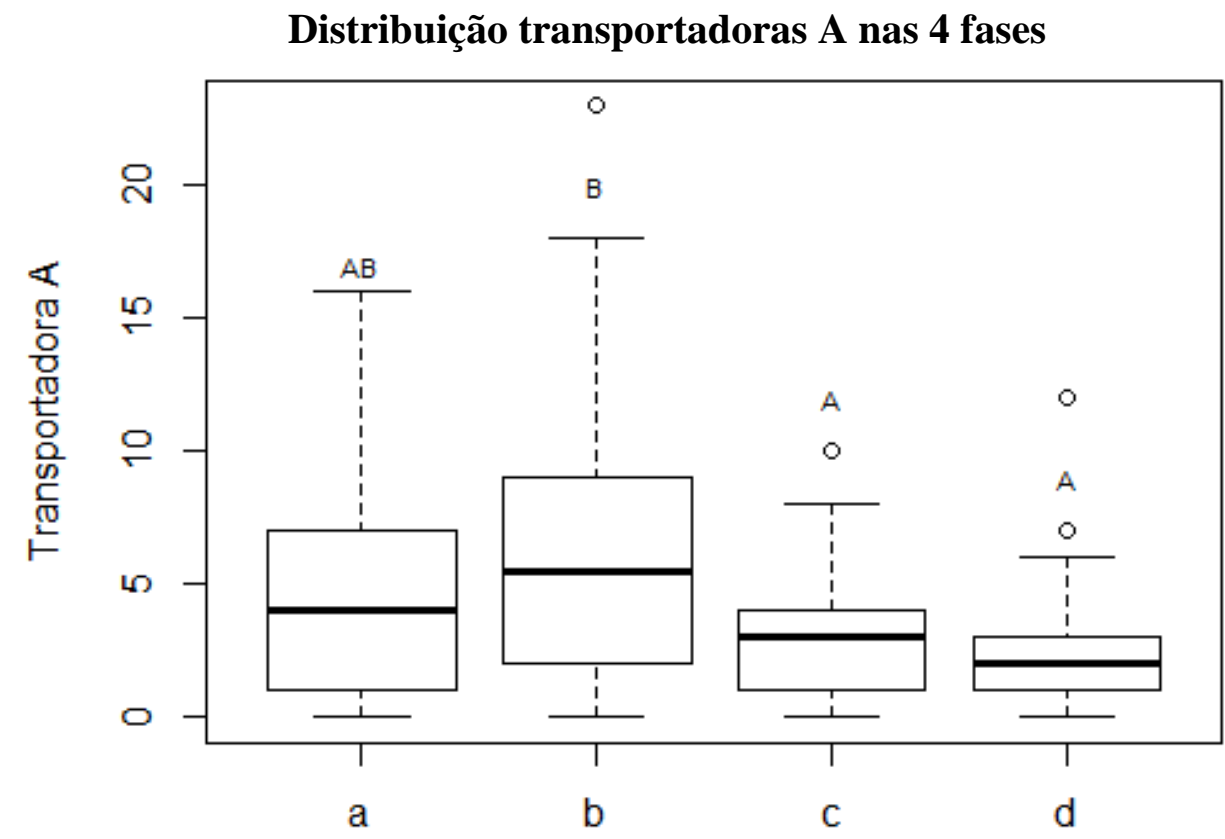

Figura 19: distribuição de transportadoras A nas diferentes fases de análise. Two-way ANOVA: $\quad F_{\text {dia }}=3.577 ; \mathrm{F}_{\text {fase }}=6.089 ; \mathrm{df}_{4}, 3,110 ; \mathrm{p}_{\mathrm{dia}}=0,008 ; \mathrm{p}_{\text {fase }}=0,0007$. As letras semelhantes acima dos boxplots codificam valores significativamente iguais em um teste post hoc de Tukey. 


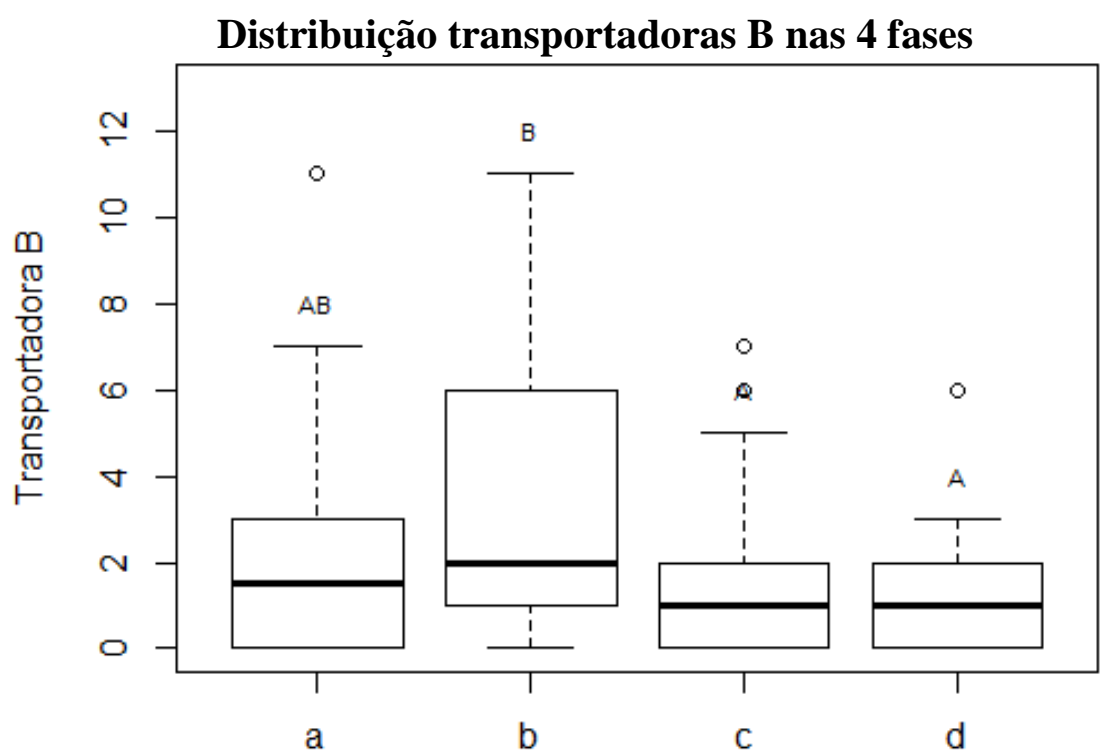

Figura 20: distribuição de transportadoras B nas diferentes fases de análise. Two-way ANOVA: $\quad F_{d i a}=2.662 ; \quad F_{\text {fase }}=4.998 ; \quad \mathrm{df}_{4}, 3,110 ; p_{\text {dia }}=0,036 ; p_{\text {fase }}=0,002$. As letras semelhantes acima dos boxplots codificam valores significativamente iguais em um teste post hoc de Tukey.

Formigas marcadas na fase $\mathrm{C}$ transportaram em todas as fases, entretanto apresentam preferencia por transportar na fase C. Ao longo dos dias não se nota um decaimento no engajamento à tarefa de transporte, ao contrario do observado nas transportadoras A e B (figura 21 e material suplementar 7). É possível observar que os níveis de transporte na fase D são intermediários entre $[\mathrm{AB}] \mathrm{e} C$.

As formigas marcadas na fase D transportam com preferência nas fases C e D. Nota-se claramente que o número de formigas D que transportaram na fase $\mathrm{A}$ e $\mathrm{B}$ é praticamente nulo. Nota-se também que não há variação do engajamento à tarefa ao longo dos dias (figura 22 e material suplementar 8).

É valido chamar a atenção para a diferença no número de formigas observadas nas medidas de atividade e nas medidas de transporte. Enquanto que o número de formigas marcadas em cada grupo variava entre 20 e 50 formigas nas medidas de atividade, o número de formigas transportando nos diferentes grupos variava entre 1 e 6 . Ou seja, apenas uma pequena fração de formigas marcadas ativas voltava a se engajar no transporte de folhas. 


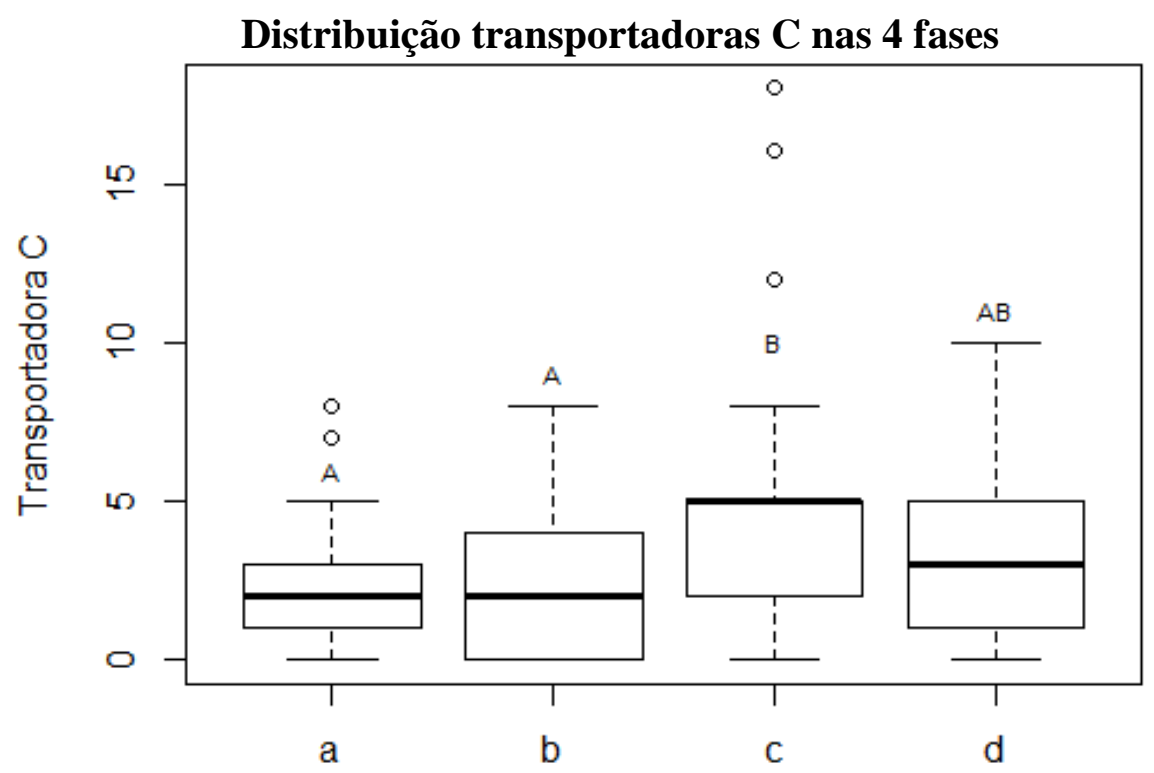

Figura 21: distribuição de transportadoras $\mathrm{C}$ nas diferentes fases de análise. Two-way ANOVA: $\quad F_{\text {dia }}=1.487 ; \quad F_{\text {fase }}=4.508 ; \mathrm{df}_{4}, 3,110 ; \mathrm{p}_{\mathrm{dia}}=0,210 ; \mathrm{p}_{\mathrm{fase}}=0,005$. As letras semelhantes acima dos boxplots codificam valores significativamente iguais em um teste post hoc de Tukey.

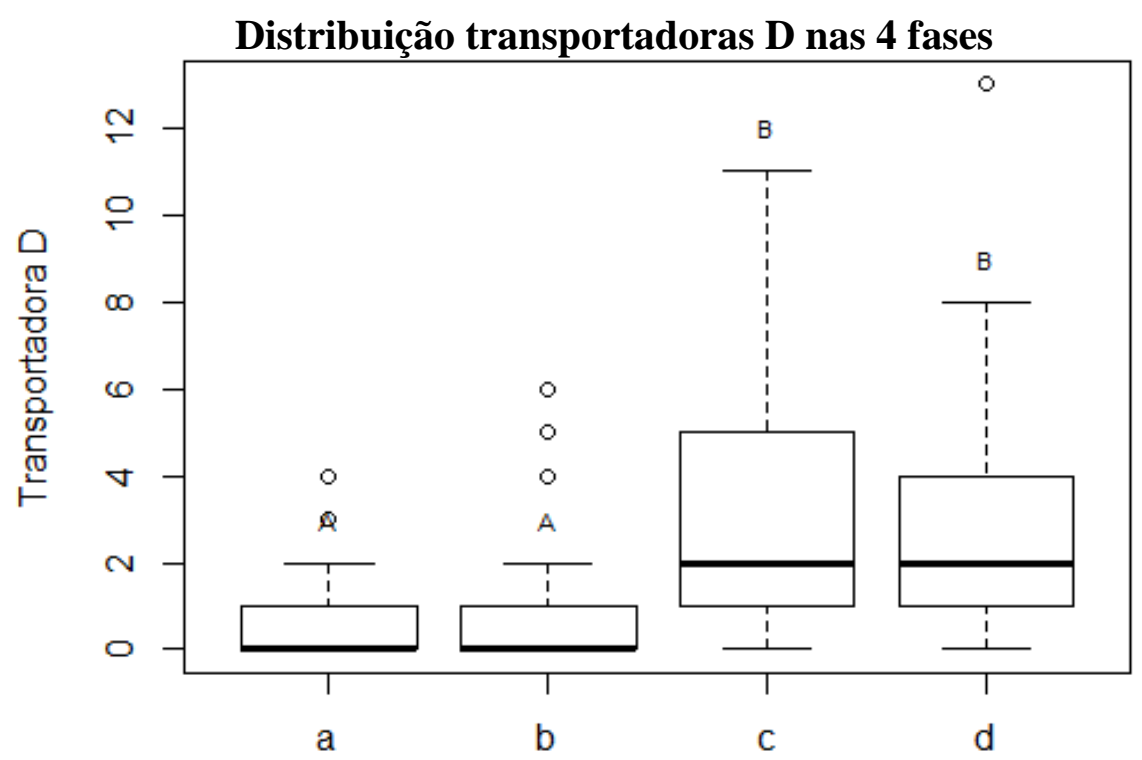

Figura 22: distribuição de transportadoras $\mathrm{C}$ nas diferentes fases de análise. Two-way ANOVA: $\mathrm{F}_{\mathrm{dia}}=1.392 ; \mathrm{F}_{\mathrm{fase}}=10,304 ; \mathrm{df}_{4}, 3,110 ; \mathrm{p}_{\mathrm{dia}}=0,241 ; \mathrm{p}_{\mathrm{fase}}<0,0001$. As letras semelhantes acima dos boxplots codificam valores significativamente iguais em um teste post hoc de Tukey. 


\subsection{Correlação entre fluxo e transporte de folhas no claro e no escuro}

Um dos fenômenos observados que mais é curioso diz respeito à porcentagem de formigas que percorrem a trilha carregando folhas. Em outras palavras, o número de formigas transitando descarregadas na trilha é muito superior ao número de formigas transportadas. Tal característica levanta questões sobre a eficiência do forrageamento em geral. De fato existem outras tarefas inerentes à formação da trilha que não estão relacionados diretamente à coleta de alimentos. Entretanto, investigar como se dá esse padrão de distribuição de formigas carregadas para formigas não carregadas é interessante para a compreensão das dinâmicas da trilha.

Nos dados coletados em média apenas $4,15 \%$ das formigas que transitaram pela trilha estavam carregando um fragmento de folha, isso independente da fase ou do dia. Quando se analisam essas porcentagens em diferentes condições de luminosidade observa-se que no claro a porcentagem de formigas carregadas é em média de 5\%. Já em escuro a porcentagem é de 3,3\%. Isso significa que a relação entre o número de formigas na trilha e o transporte de folhas muda conforme as fases do dia.

A figura 23 mostra a correlação entre o número total de formigas transportadoras e o fluxo estimado na trilha. Neste mesmo gráfico estão diferenciados os eventos que ocorreram durante o dia e os eventos que ocorreram à noite. Nota-se claramente que a relação entre os eventos de transporte de folhas e o fluxo são diferentes na fase de claro e na fase de escuro. Na fase de claro o coeficiente da regressão linear é maior do que na fase de escuro. O que significa que durante o dia a proporção de formigas transportadoras pelo fluxo é sempre maior do que durante a noite.

Uma análise de regressão linear múltipla indica que existe uma correlação positiva e linear entre o fluxo e o transporte de folhas tanto no claro como no escuro. Essa análise também indica que o coeficiente dessas correlações é diferente nas duas fases. Ou seja, a relação entre fluxo e transporte de folhas é diferente nas duas fases observadas.

Da figura 23 é possível extrair a mesma informação que foi mostrada na figura 7: o fluxo total é maior, em média, na fase de escuro do que na fase de claro. Esse mesmo padrão é observado para o transporte. Entretanto, como mostram as regressões, as proporções mudam e isso possui um significado biológico que será discutido mais a frente. 


\section{Correlação entre fluxo de formigas e transporte de folhas no claro e no escuro}

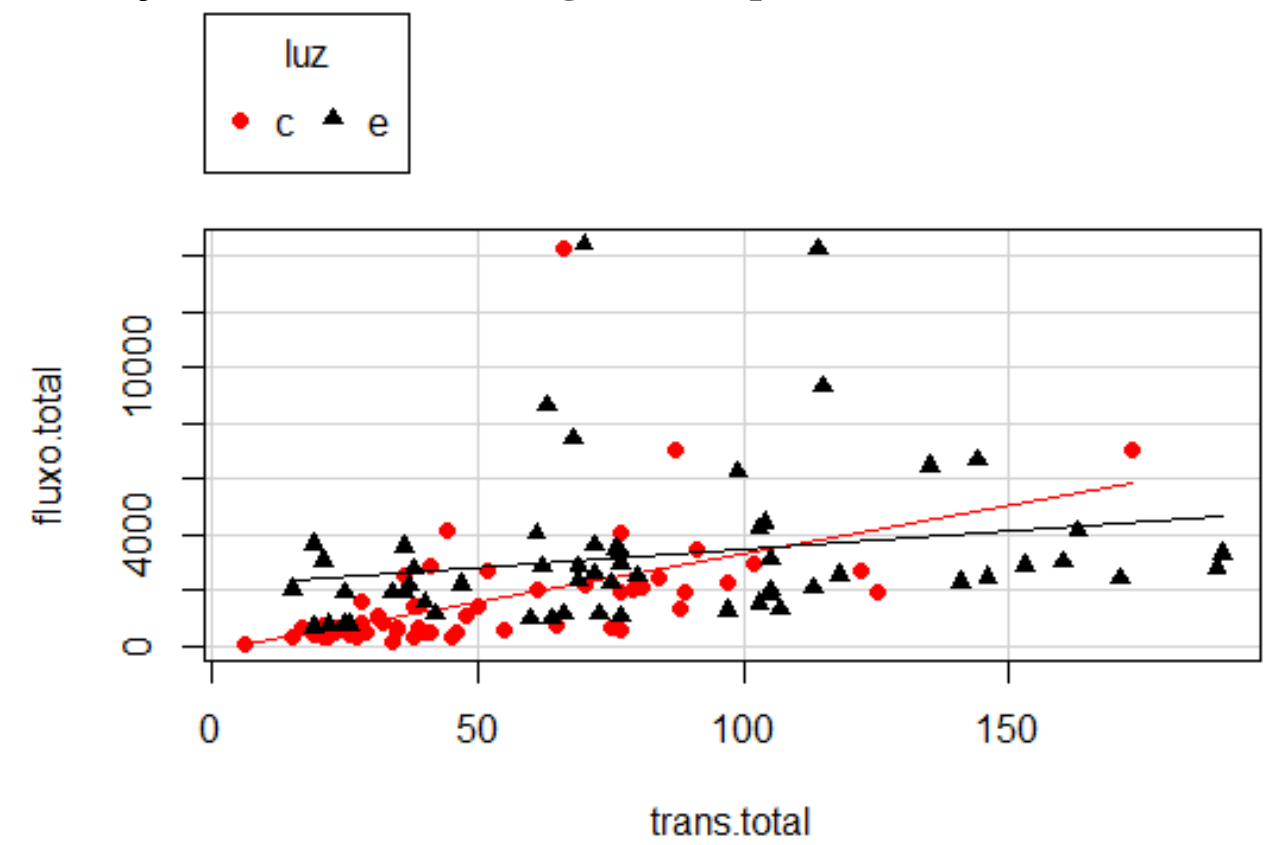

Figura 23: Correlação entre os valores observados de fluxo total e transporte de folhas nas fases de claro e escuro. Regressão linear múltipla:

\subsection{Análise da morfometria das formigas}

Ao total foram medidas 705 formigas nos 400 frames obtidos das gravações das réplicas 4 e 5. Das 705 formigas, 120 foram medidas na fase A; 147 na fase B; 255 na fase $\mathrm{C}$ e 183 na fase D. Consequentemente, 267 formigas foram medidas em condição de claro e 438 foram medidas em condição de escuro. Note que essa distribuição se assemelha a distribuição do fluxo, como observado nas figuras 7 e 8 .

A análise dos dados obtidos permite identificar se as formigas que aparecem nas diferentes fases e diferentes condições de iluminação são de tamanhos diferentes. A figura 24 mostra a distribuição de tamanho das formigas nas condições de claro e escuro. Note que as formigas que aparecem em claro são maiores que as formigas que aparecem em escuro. Essas distribuições são significativamente distintas como mostra o teste $\mathrm{T}(\mathrm{t}=17.144, \mathrm{df}=660,65, \mathrm{p}<0,0001)$.

É possível analisar também a distribuição do tamanho das formigas nas 4 diferentes fases de análise. Tal distribuição é mostrada na figura 25. Nota-se que as formigas que aparecem em A e B são maiores que as formigas que aparecem em C e D. 
Essas diferenças são corroboradas pela análise de variância (ANOVA: F=88.04, $\mathrm{df}_{3,701}$; $\mathrm{p}<0,0001)$. Tal distribuição indica que a principal diferença entre as formigas se dá principalmente pelas condições de iluminação e não por alguma fase mais restrita.

\section{Tamanho do corpo das formigas de claro e de escuro}

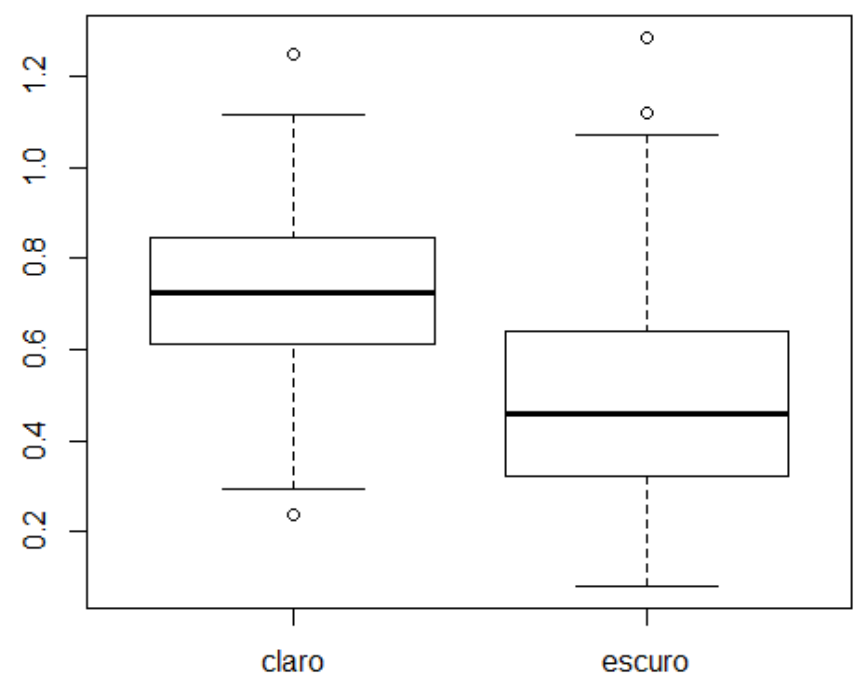

Figura 24: distribuição do tamanho das formigas observadas em claro e em escuro. Teste $\mathrm{T}: \mathrm{t}=17.144, \mathrm{df}=660,65, \mathrm{p}<0,0001$.

\section{Tamanho do corpo das formigas nos diferentes turnos}

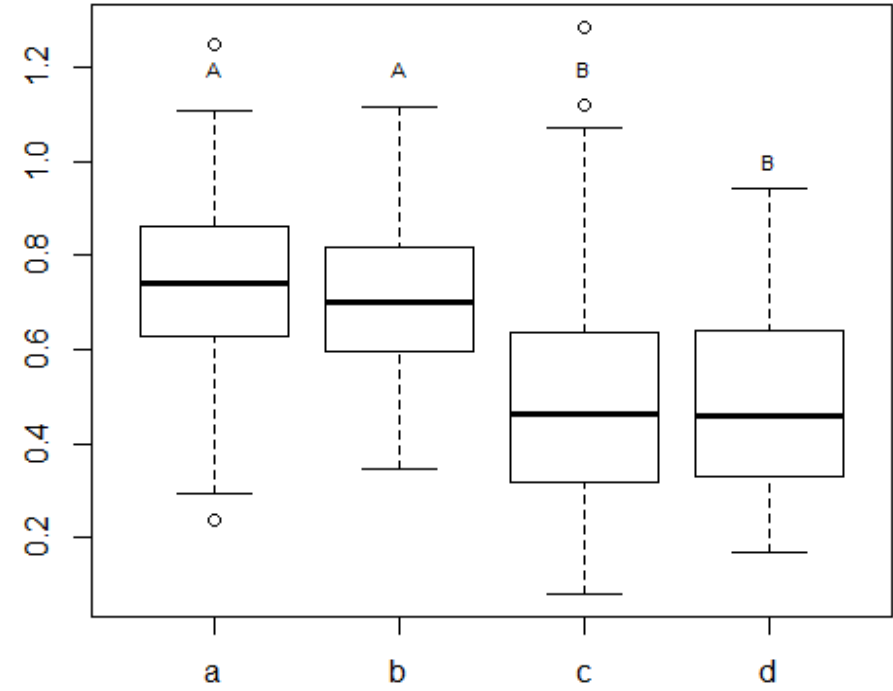

Figura 25: distribuição do tamanho das formigas observadas nas 4 diferentes fases de observação. ANOVA: $\mathrm{F}=88.04, \mathrm{df}_{3,701} ; \mathrm{p}<0,0001$. As letras acima dos boxplots representam valores significativamente semelhantes pelo teste post hoc de Tukey. 


\section{Discussão}

Os resultados mostram que: (1) a colônia possui um ritmo de atividade, expresso pelo fluxo de formigas na trilha e pelo transporte de folhas, no qual a maior atividade ocorre na fase de escuro; (2) as formigas que forrageiam na fase de claro e de escuro constituem dois grupos distintos, cuja atividade preferencial se mantém a mesma ao longo do tempo; (3) as formigas que constituem esses grupos distintos são diferentes no que diz respeito ao tamanho, formigas diurnas são maiores que formigas noturnas; e (4) essa divisão temporal de tarefas observada faz com que o forrageamento seja mais eficiente na fase de claro do que na fase de escuro.

A maior vantagem de estudar organismos eussociais em laboratório é poder controlar as variáveis ambientais em um espectro mais restrito do que o observado na natureza. Entretanto, trazer os organismos sociais para o laboratório também trás uma serie de desafios. Se em laboratório é possível controlar as variáveis ambientais, como elaborar um protocolo que permita a observação dos comportamentos de interesse sem perda da complexidade inerente do sistema? O protocolo aqui utilizado pareceu suprir esses desafios. Como mostrado nas figuras 9 e 16 o fluxo de formigas e o transporte de folhas não muda ao longo dos dias. Argumenta-se com base nesses dados que o controle das condições ambientais e da alimentação dessas formigas gerou uma demanda constante para a realização das tarefas de interesse. Em outras palavras, não houve estímulo para que as formigas mudassem seu padrão de atividade e comportamentos. Portanto, é seguro afirmar que qualquer variação observada se dá apenas pelas diferenças da condição que continuou variando: claro e escuro.

Claramente a colônia possui dois estados diferentes de atividade. Atividade reduzida durante a fase de claro e atividade alta durante a fase de escuro, como mostra a figura 7. Uma vez que as condições ambientais (exceto a luminosidade) permaneceram constantes ao longo do experimento, é possível argumentar que essa variação se dá em função de alguma dinâmica interna da colônia, em relação à condição de iluminação. Afirma-se, portanto, que a colônia, como um sistema social, é noturna.

Mais especifico que simplesmente dia e noite, os dados obtidos permitem observar certa dinâmica temporal circadiana da colônia. Nota-se que em ambos os 
turnos da fase de claro (A e B) a atividade geral das forrageadoras permaneceu igualmente baixa quando comparada ao pico de atividade observado no turno C. Logo em seguida, ocorre uma diminuição gradual da atividade no turno $\mathrm{D}$, como demonstrado na figura 8. É possível levantar a hipótese de que a colônia possui uma variação diária de atividade que apresenta um pico no meio na noite ( $22 \mathrm{~h} 00$ às $00 \mathrm{~h} 00$ ) e vai decaindo entre a madrugada (02h00 às 04h00) até alcançar níveis relativamente baixos durante o todas as horas da fase de claro.

Esses resultados são condizentes com os observados por Lewis et al. (1974) em Atta cephalotes, assim como com os dados coletados anteriormente em nosso laboratório (ARRUDA et al., não publicado). Lewis et al. (1974) descrevem que a atividade coletiva de forrageamento das formigas varia ao longo do dia, sendo maior durante a noite e praticamente inexistente durante o dia. Os dados apresentados nesse trabalho dizem respeito ao verão. Entretanto, nesse mesmo artigo, os autores descrevem que no inverno existe uma inversão da fase de forrageamento. No inverno a atividade é maior durante o dia e praticamente inexistente durante a noite. Vale ressaltar, portanto, que o fotoperíodo adotado no presente trabalho é equivalente ao verão, caso as $A$. sexdens apresentem as mesmas variações observadas em $A$. cephalotes.

Essa relação entre a fase de atividade preferencial das formigas e as diferentes fases do dia já foi descrita em outras espécies. A tabela 1 trás um resumo da descrição da fase de atividade preferencial de 21 espécies de formigas. Nessa tabela está discriminada (1) a atividade preferencial dessas espécies nas estações de outonoinverno e primavera-verão, (2) se há atividade na fase oposta à preferencial, (3) a localidade onde os dados foram coletados e (4) as referências de onde as informações foram retiradas. É possível perceber que todas as espécies de formigas apresentam uma fase de atividade preferencial. Em outras palavras, todas as colônias podem ser classificadas como noturnas ou diurnas. Mais ainda, essa relação pode se alterar conforme as estações do ano.

Os dados da tabela 1 foram coletados em campo. Portanto, nenhuma condição ambiental foi controlada. Como a maioria dos trabalhos apresentados mostra existe um correlato forte entre a atividade das formigas e as condições do ambiente no qual elas se inserem, especialmente a temperatura. Tal correlato faz todo o sentido biológico, uma vez que as formigas são ectotérmicas e não possuem mecanismos endógenos de 
Tabela 1: resumo da descrição da fase de atividade preferencial para 21 espécies de formigas. $O$ asterisco $(*)$ indica informações não disponíveis.

\begin{tabular}{|c|c|c|c|c|c|}
\hline \multirow[b]{2}{*}{ Espécie } & \multicolumn{2}{|c|}{ 1. Atividade preferencial } & \multirow{2}{*}{$\begin{array}{c}2 . \\
\text { Atividade } \\
\text { na fase } \\
\text { oposta }\end{array}$} & \multirow[b]{2}{*}{$\begin{array}{c}3 . \\
\text { Localidade }\end{array}$} & \multirow[b]{2}{*}{$\begin{array}{c}4 . \\
\text { Referência }\end{array}$} \\
\hline & $\begin{array}{l}\text { Outono- } \\
\text { inverno }\end{array}$ & $\begin{array}{l}\text { Primavera- } \\
\text { verão }\end{array}$ & & & \\
\hline Atta cephalotes & Dia & Noite & Sim & Trinidad & $\begin{array}{l}\text { Lewis et al., } \\
1974\end{array}$ \\
\hline $\begin{array}{l}\text { Anoplolepis } \\
\text { gracilipes }\end{array}$ & Noite & $*$ & Sim & Malásia & $\begin{array}{l}\text { Chong \& } \\
\text { Lee, } 2009\end{array}$ \\
\hline $\begin{array}{l}\text { Cataglyphis } \\
\text { cursor }\end{array}$ & Dia & Dia & Não & \begin{tabular}{|l|} 
Mediterrâne \\
o
\end{tabular} & $\begin{array}{l}\text { Cros, et al., } \\
1997\end{array}$ \\
\hline $\begin{array}{l}\text { Camponotus } \\
\text { foreli }\end{array}$ & Dia & Dia & Não & \begin{tabular}{|l} 
Mediterrâne \\
o
\end{tabular} & $\begin{array}{l}\text { Cros, et al., } \\
1997\end{array}$ \\
\hline $\begin{array}{l}\text { Aphaenogaster } \\
\text { senilis }\end{array}$ & Dia & Dia & Não & $\begin{array}{l}\text { Mediterrâne } \\
\text { o }\end{array}$ & $\begin{array}{l}\text { Cros, et al., } \\
1997\end{array}$ \\
\hline Messor bouvieri & Noite & Dia & Sim & $\begin{array}{l}\text { Mediterrâne } \\
\mathrm{o}\end{array}$ & $\begin{array}{l}\text { Cros, et al., } \\
1997\end{array}$ \\
\hline $\begin{array}{l}\text { Messor } \\
\text { capitatus }\end{array}$ & Noite & Dia & Sim & \begin{tabular}{|l} 
Mediterrâne \\
o
\end{tabular} & $\begin{array}{l}\text { Cros, et al., } \\
1997\end{array}$ \\
\hline $\begin{array}{l}\text { Camponotus } \\
\text { cruentatus }\end{array}$ & Noite & Dia & Sim & \begin{tabular}{|l} 
Mediterrâne \\
o
\end{tabular} & $\begin{array}{l}\text { Cros, et al., } \\
1997\end{array}$ \\
\hline $\begin{array}{l}\text { Tapinoma } \\
\text { nigerrimum }\end{array}$ & Noite & Dia & Sim & $\begin{array}{l}\text { Mediterrâne } \\
\text { o }\end{array}$ & $\begin{array}{l}\text { Cros, et al., } \\
1997\end{array}$ \\
\hline $\begin{array}{l}\text { Pheidole } \\
\text { pallidula }\end{array}$ & Noite & Noite & Sim & $\begin{array}{l}\text { Mediterrâne } \\
\mathrm{o}\end{array}$ & $\begin{array}{l}\text { Cros, et al., } \\
1997\end{array}$ \\
\hline $\begin{array}{l}\text { Tetramorium } \\
\text { semilaeve }\end{array}$ & Noite & Noite & Sim & \begin{tabular}{|l|} 
Mediterrâne \\
o \\
\end{tabular} & $\begin{array}{l}\text { Cros, et al., } \\
1997\end{array}$ \\
\hline $\begin{array}{l}\text { Camponotus } \\
\text { sylvaticus }\end{array}$ & Noite & Noite & Sim & \begin{tabular}{|l} 
Mediterrâne \\
o
\end{tabular} & $\begin{array}{l}\text { Cros, et al., } \\
1997\end{array}$ \\
\hline $\begin{array}{l}\text { Acromyrmex } \\
\text { subterraneus }\end{array}$ & Dia & Dia & Sim & Brasil & $\begin{array}{l}\text { Nickele, } \text { et } \\
\text { al., } 2016\end{array}$ \\
\hline $\begin{array}{l}\text { Acromyrmex } \\
\text { crassipinus }\end{array}$ & Dia & Dia & Sim & Brasil & $\begin{array}{l}\text { Nickele, et } \\
\text { al., } 2016\end{array}$ \\
\hline $\begin{array}{l}\text { Pogonomyrmex } \\
\text { pronotalis }\end{array}$ & Dia & Noite & Sim & Argentina & $\begin{array}{l}\text { Pol \& De } \\
\text { Casenave, } \\
2004\end{array}$ \\
\hline $\begin{array}{l}\text { Pogonomyrmex } \\
\text { rastratus }\end{array}$ & Dia & Noite & Sim & Argentina & $\begin{array}{l}\text { Pol \& De } \\
\text { Casenave, } \\
2004\end{array}$ \\
\hline $\begin{array}{l}\text { Myrmecia } \\
\text { croslandi }\end{array}$ & & ia & Não & Austrália & $\begin{array}{l}\text { Narendra e. } \\
\text { al., } 2011\end{array}$ \\
\hline $\begin{array}{l}\text { Myrmecia } \\
\text { tarsata }\end{array}$ & & ia & Não & Austrália & $\begin{array}{l}\text { Narendra e. } \\
\text { al., } 2011\end{array}$ \\
\hline $\begin{array}{l}\text { Myrmecia } \\
\text { nigriceps }\end{array}$ & & ite & Sim & Austrália & $\begin{array}{l}\text { Narendra e. } \\
\text { al., } 2011\end{array}$ \\
\hline $\begin{array}{l}\text { Mirmecia } \\
\text { pyriformes }\end{array}$ & & ite & Não & Austrália & $\begin{array}{l}\text { Narendra e. } \\
\text { al., } 2011\end{array}$ \\
\hline $\begin{array}{l}\text { Camponotus } \\
\text { giga }\end{array}$ & & ite & Sim & Brunei & $\begin{array}{l}\text { Orr \& } \\
\text { Charles, } \\
1994\end{array}$ \\
\hline
\end{tabular}


termorregulação, apenas os comportamentais. Existe uma temperatura ambiente ótima para a fisiologia do animal e existe também uma temperatura ambiente crítica na qual todas as funções fisiológicas e comportamentais colapsam (RIBEIRO et al., 2012). Consequentemente, as formigas estudadas nesses trabalhos podem ter atividade preferencial nas condições mais adequadas para suas respectivas fisiologias e não apresentar atividade nenhuma na fase cujas condições são inadequadas.

Existem algumas espécies que apresentam atividade mesmo na fase oposta à preferencial, de maneira semelhante ao observado para as saúvas. Esses casos levantam as mesmas questões abordadas nessa pesquisa. Será que as formigas que forrageiam na fase oposta à preferencial são as mesmas? Existe algum mecanismo de divisão temporal de tarefas? Se não são as mesmas, quais seriam as diferenças entre elas?

Vale ressaltar que a medida utilizada para verificação da atividade preferencial em todos os trabalhos é coletiva. Ou seja, verificou-se o número de formigas que estavam forrageando em um determinado momento ao longo do dia. Portanto, esses trabalhos ainda não apresentam dados para responder se as formigas observadas forrageando nas diferentes horas do dia são as mesmas, ou, se de alguma forma, elas dividem temporalmente a tarefa de forrageamento.

Já que as questões levantadas são semelhantes, o modelo das saúvas utilizado nesse trabalho pode decorrer em um modelo que auxilie a responder essas questões. Os resultados aqui apresentados também podem ajudar a esclarecer a relação entre os indivíduos e as variações ambientais, principalmente relacionadas à condição de iluminação.

\subsection{Distribuição temporal da atividade de formigas marcadas}

Os resultados apresentados mostram a existência de dois grandes grupos: formigas que forrageiam preferencialmente no claro e formigas que forrageiam preferencialmente no escuro (figura 10). Esses dois grandes grupos de formigas apresentam relação diferente de sua fase de atividade com as condições de iluminação. Entretanto, essa relação não é de exclusividade, sendo possível observar uma parcela de formigas de um determinado grupo forrageando na fase oposta à de preferência. Tomando esses dados em conjunto, parece possível afirmar que esses dois grupos 
representam castas temporais, ou seja, grupos de formigas especializados no forrageamento em diferentes fases do dia.

A interpretação de que há uma determinação temporal da atividade é corroborada pela observação, mais precisa temporalmente, dos grupos marcados nos diferentes turnos (A, B, C e D). A figura 11 mostra justamente essa tendência das formigas marcadas de retornarem a atividade com maior frequência no mesmo turno em que foi marcada, e na mesma condição de iluminação. Formigas marcadas entre $14 \mathrm{~h} 00$ e $16 \mathrm{~h} 00$, e $22 \mathrm{~h} 00$ e $00 \mathrm{~h} 00$ voltam a aparecer com maior frequência em seus respectivos turnos (figuras 13 e 14). Enquanto que formigas marcadas entre $10 \mathrm{~h} 00 \mathrm{e}$ 12h00, e 02h00 e 04h00 apresentam maior atividade nos turnos B e C respectivamente (figuras 12 e 15), mostrando consistência com a fase, mesmo havendo diferença no turno. Esse resultado dá sustentação à existência de grupos separados de formigas que forrageiam em diferentes fases do dia.

As formigas marcadas em A e D aparecerem mais em $\mathrm{B}$ e $\mathrm{C}$ respectivamente. Fica claro que a troca de turno de atividade preferencial ocorreu pelo outro turno na mesma condição de iluminação em ambos os casos. Ou seja, formigas A, que foram marcadas em claro, apareceram mais em B, que também é condição de claro; e formigas D, marcadas em escuro, foram observadas com mais frequência em C, que também é um turno na fase de escuro.

Tais resultados sustentam a ideia de que a diferença na atividade das formigas é dada principalmente pela relação das operárias com a condição de iluminação. Já que a preferência de atividade de formigas marcadas em A e D ocorreu no outro turno da mesma fase (B e C, respectivamente), é possível argumentar que a diferença de 2 horas entre turnos na mesma fase não expressam a duração do turno de trabalho das formigas. Em outras palavras, o tuno de atividade das formigas é maior que 6 horas, dado o intervalo de tempo entre turnos de mesma fase. Ou seja, o principal fator que determina a divisão temporal de tarefas por formigas saúva nesse caso é a fase.

Vale ressaltar que esses padrões observados permanecem constantes ao longo do tempo. Ou seja, mesmo com o passar dos dias, as formigas voltam à atividade na mesma condição de iluminação. Entretanto, essa medida é valida apenas para os 5 dias de observação que foram definidos pela metodologia. Não se sabe se em escalas temporais maiores existe esse padrão se mantém ou se há troca da fase ou do turno 
preferencial de atividade.

É sabido que as abelhas, um sistema social muito semelhante, ao envelhecer, migram de uma tarefa para outra, o que é chamado de polietismo de idade. Além disso, a idade dos indivíduos é extremamente relacionada à maneira que eles se relacionam com os ciclos ambientais. Enfermeiras são abelhas mais jovens apresentam atividade arrítmica ao longo das 24 horas, já as forrageadoras são mais velhas e sua atividade é fortemente sincronizada com o ritmo de claro-escuro (NICHOLAS \& CALDERONE, 1998). Um padrão semelhante de polietismo de idade poderia ser observado nas saúvas caso o tempo de observação fosse mais extenso. Entretanto, o polietismo de idade, caso ocorra em Atta sexdens, poderia dificultar a interpretação dos resultados apresentados neste trabalho, já que não se sabia a idade das operárias que foram marcadas. Caso o tempo de observação fosse grande o suficiente para captar as possíveis variações decorrentes do polietismo de idade, os resultados apresentariam diversas formigas de diferentes idades que migram de fase preferencial de atividade em diferentes momentos da observação. Se tal evento de fato ocorresse, o número de formigas marcadas observadas nas diferentes fases e turnos tenderia a se igualar devido à troca $\mathrm{e}$ se tornaria difícil a verificação sem um método claro de avaliação de idade das formigas.

Outro fator aparentemente relevante diz respeito à atividade das formigas marcadas nos turnos imediatamente adjacentes ao turno preferencial. Para todos os 4 grupos de formigas marcadas existe um turno preferencial e outro turno cuja atividade é significativamente menor. Nos 4 grupos de formigas marcadas o turno cuja atividade foi menor foi o turno temporalmente mais distante do turno de atividade preferencial. Os dois turnos adjacentes tendem a apresentar valores intermediários entre o pico de atividade preferencial e o turno de menor atividade. Como esses turnos de marcação/observação são temporalmente espaçados com intervalos de tempo definidos pela metodologia (figura4), é razoável levantar alguma hipótese sobre a duração média da fase de atividade dos grupos de formiga: 2 horas separam turnos dentro de uma mesma condição de iluminação; 6 horas separam turnos em diferentes condições de iluminação; e 12 horas separam fases opostas (claro-escuro). Se as formigas estão significativamente mais ativas em uma fase, com as fases adjacentes apresentando valores intermediários, discute-se que as formigas possam apresentar 10 horas de fase de atividade em média, com o restante do tempo em repouso. Dessa forma é razoável 
esperar que elas apareçam com o pico de atividade no turno focal, com valores intermediários nos turnos adjacentes e atividade reduzida no turno oposto, como os resultados obtidos mostram. Nesse contexto, como não havia a identificação individual das formigas se torna difícil estabelecer se essa hipótese encontra corroboração.

Para identificar com precisão os ritmos de atividade individual de cada operária seria necessário separá-las e analisa-las individualmente a fim de produzir os actogramas. Porém, a separação das formigas pode causar disfunção de seus ritmos de atividade natural, porque a organização social é importante para a expressão dos comportamentos. Inclusive, a sincronização da atividade pelo contato social é um processo que já foi descrito e é necessário para a manutenção da colônia (LONE \& SHARMA, 2011).

Vale ressaltar que, mesmo que as todas as saúvas de uma mesma colônia apresentem ritmos de 10 horas de atividade e 14 horas de repouso, ainda assim existiriam grupos diferentes de formigas nos quais esses ritmos se relacionariam de forma diferenciada com o ciclo ambiental. Isso porque os resultados mostram claramente que grupos diferentes de formigas apresentam atividade preferencial em horas diferentes do dia. A figura 27 busca representar como seriam a atividade dessas diferentes castas temporais, baseando-se nos dados coletados.

Pouco se sabe sobre os ritmos individuais de atividade em formigas. Portanto, há poucas evidências que suportem a afirmação de que as saúvas possam apresentar um ritmo de atividade/repouso de 10/14 horas. Os poucos trabalhos que se propuseram a identificar os padrões de atividade e repouso em formigas foram com a espécie Camponotus compressus. Esses trabalhos identificaram que, em fotoperíodo de 12/12 e condições de temperatura, umidade e alimentação constantes, operárias de $C$. compressus dividem-se em três grupos: noturnas, diurnas e arrítmicas. Nos grupos identificados as formigas permaneciam constantemente ativas durante toda a sua fase de atividade preferencial, quando elas eram sincronizadas (diurnas ou noturnas). Aparentemente as formigas permaneciam ativas constantemente durante a fase de atividade, fosse ela no claro ou no escuro (SHARMA et al. 2004), . Como o fotoperíodo do experimento foi definido em 12:12 LD, afirma-se que essas formigas permaneciam ativas por 12 horas. Esses resultados obtidos com a C. compressus são semelhantes aos observados aqui com $A$. sexdens no sentido de ambas as espécies de formigas apresentarem um determinado padrão de atividade que é constante para todas 
as operárias, mas que é desviado de fase, dependendo do grupo analisado.

Baseando-se nos resultados apresentados por Sharma et al. (2004a, 2004b) não se descarta a possibilidade da existência de um grupo de formigas arrítmicas dentro das colônias de Atta sexdens. Isso porque foram observadas formigas marcadas de todos os grupos em todas as fases e turnos, mesmo nas fases e turnos de menor atividade. Talvez, algumas das formigas marcadas pertençam a esse grupo de formigas arrítmicas. Nesse caso, faz sentido que essas formigas, que foram marcadas erroneamente em um determinado grupo, sejam observadas em todas as fases, inclusive naquela de menor atividade. Essa questão poderia ter sido abordada caso as formigas fossem marcadas individualmente.

\subsection{Distribuição temporal do engajamento de formigas transportadoras}

Como discutido anteriormente, a atividade de transporte de folhas permanece constante ao longo dos dias e isso pode ser um indicador para afirmar que o protocolo de alimentação ad libidum não criou demandas ou déficits de nutrição para as formigas. A variação observada no transporte de folhas, portanto, se dá em função das diferentes fases e turnos de observação.

Seguindo o mesmo padrão do fluxo de formigas, o transporte ocorre preferencialmente durante a noite (figura 11), sendo que a maior frequência de transporte ocorre nos turnos C e D e a menor frequência ocorre na fase A (figura 12). Não é coincidência que o padrão do fluxo total se repita para a tarefa de transporte de folhas. Faz sentido que quanto mais operárias tenham na trilha, maior será o transporte de folhas.

Apesar da tarefa de transporte ser realizada com a mesma frequência ao longo dos dias, as formigas que se engajam nessa tarefa não são as mesmas. Como dá para notar o número de formigas marcadas que voltaram a forragear foi baixo em relação ao número de formigas marcadas que voltaram a transitar pela trilha. Em outras palavras, as formigas foram marcadas inicialmente transportando folhas e não foram observadas retornando a essa atividade. Poucas formigas marcadas voltaram a transportar independente do grupo ao qual elas pertencem. $\mathrm{O}$ baixo número de formigas $\mathrm{C}$ e $\mathrm{D}$ que 
voltaram a transportar manteve-se constante ao longo dos 5 dias. Já o número de formigas marcadas em A e B que voltou a transportar folhas apresentou uma tendência de queda nos últimos 3 dias de experimento (material suplementar 5, 6, 7 e 8).

Como não havia distinção individual das formigas marcadas em um mesmo grupo não é possível afirmar se as formiga que voltaram a transportar eram as mesmas. Entretanto, isso não diminui o efeito da queda no engajamento à tarefa de transporte.

Esses dados também sugerem que a marcação feita nas formigas está mais relacionada ao turno de atividade no qual elas aparecem do que na tarefa na qual elas se engajam. De acordo com a metodologia, esse engajamento teve a função de explicitar que a formiga marcada estava de fato em sua fase de atividade e não perambulando a esmo na trilha. Os resultados mostram que esse critério foi capaz de selecionar formigas cuja atividade ocorre em uma fase de preferência. Entretanto, a atividade das formigas mostrou-se completamente dissociada do engajamento a alguma tarefa. Outro estudo feito em saúvas que visava identificar se formigas de mesma casta morfológica permaneciam constantemente engajadas na mesma tarefa mostrou um padrão similar de queda de engajamento. O constante acompanhamento de formigas que se engajaram nas tarefas de corte de folhas e exploração de novos territórios mostrou que ambas as tarefas eram realizadas com a mesma frequência pela colônia; mas as formigas que foram inicialmente observadas realizando essas tarefas foram gradativamente sendo substituídas por outras. Entretanto, essas formigas iniciais não deixaram de ser observadas, elas apenas não se engajaram nas tarefas (CONSTANTINO et al., , não publicado).

Vale ressaltar que o número de formigas carregando folhas era baixo em comparação com o fluxo total. Em média, apenas $2,7 \%$ das formigas que transitavam na trilha estavam carregando fragmentos de folhas. Portanto, faz sentido que o número de formigas marcadas observadas que permaneceram engajadas na tarefa de transporte de folhas tenha sido baixo. Isso porque a proporção natural de formigas na trilha que estão engajadas na tarefa de transporte é baixa. Entretanto, esses dados levantam questões acerca da eficiência no desempenho da tarefa de forrageamento. 


\subsection{Eficiência no transporte de folhas em diferentes fases}

Existe uma relação de proporcionalidade entre o fluxo de formigas na trilha e o transporte de folhas. A correlação é positiva, quanto mais formigas na trilha maior é o transporte de folhas. Entretanto, essa proporção não é a mesma para o dia e para a noite.

Como mostram os dados (figura 23), a relação entre o fluxo de formigas na trilha e o transporte de folhas é diferente entre a fase de claro e a fase de escuro. Em ambos os casos a correlação é positiva, mas durante a fase de claro o coeficiente de reta da regressão é significativamente maior do que na fase de escuro. Isso significa que durante a fase de claro a dependência entre o número de formigas transportadoras/não-transportadoras é maior do que na fase de escuro. Mais ainda as proporções eram diferentes, $5 \%$ de dia e $3,3 \%$ de noite.

É possível argumentar que a eficiência na coleta de alimentos, no caso fragmentos de folha, é dada pela quantidade de folhas coletadas em função do número de formigas que percorreu a trilha. Nesse contexto, é razoável afirmar que a eficiência na coleta de alimento é maior na fase de claro do que na fase de escuro. Por mais que mais folhas tenham sido transportadas durante a fase de escuro, foi necessário menos esforço coletivo (i. e. formigas na trilha) para maior coleta de alimento na fase de claro. $\mathrm{Na}$ fase de claro, mais unidades de alimento foram coletadas por formiga do que na fase de escuro.

Os dados aqui apresentados não indicam a quantidade real de folhas coletadas, uma vez que não foi medido o peso das folhas coletadas. Formigas de tamanhos diferentes cortam fragmentos de folhas de tamanhos diferentes (citar nosso trabalho de 2016). Isso porque o corte das folhas é feito pelas operárias em um movimento de compasso: as formigas se apoiam sobre as pernas traseiras e deslocam a mandíbula em compasso até que o fragmento seja cortado. Isso implica que formigas maiores cortam fragmentos de folhas maiores do que formigas menores (WETTERER, 1994; BURD, 1995). Uma vez que foi observada a diferença real do tamanho das formigas que forrageiam na fase de claro e na fase de escuro, é razoável assumir que o tamanho das folhas coletadas durante a fase de claro são maiores que os fragmentos coletados na fase de escuro. É plausível que, se for levado em consideração o tamanho dos fragmentos de folha coletados, a relação entre quantidade de alimento transportado 
possa ser a mesma entre as fases de claro e escuro, por mais que a relação entre o fluxo e o transporte seja diferente. Entretanto, por mais que esse cenário seja possível, ele só acentua a diferença entre a relação quantidade de alimento coletado por esforço coletivo. Essa relação diferencial entre fluxo e transporte existe e mais investigações acerca desse fenômeno são válidas.

Essa, aparentemente, é a primeira descrição de que o forrageamento de formigas cortadeiras não segue a mesma regra de proporcionalidade ao longo do dia. Em outras palavras, por algum motivo ainda desconhecido, durante a noite saem mais formigas sem se engajar no forrageamento do que durante o dia.

Tais observações levantam a questão sobre qual a função das formigas não carregadas na trilha. Obviamente que o desenho experimental deste trabalho influencia na disposição espacial das formigas, já que elas foram criadas em um espaço restrito. Por outro lado, diversas observações feitas nas trilhas das saúvas em colônias de campo indicam que a proporção de formigas carregadas na trilha é baixa.

Aparentemente toda a tarefa de transporte de folhas não é 'otimizada'. Mesmo em campo aproximadamente $50 \%$ dos fragmentos de folha cortados não são carregados de volta para o ninho e acabam por se acumular e formar os chamados 'caches' próximos à fonte de alimento. Também há descrição da formação desses caches na entrada do ninho. Detectou-se que esses caches se formam em condições especificas como, por exemplo, quando a capacidade de processamento interno dos fragmentos de folha é excedida, ou quando algum tipo de obstáculo se forma na trilha (HART \& RATNIEKS, 2000). Entretanto, esse mecanismo aparentemente aumenta a chance de fragmentos de folhas serem recolhidos e eventualmente serem incorporados ao ninho (HART \& RATNIEKS, 2001).

Outro dado surpreendente mostra que em colônias de Temnothorax rugatulus $45 \%$ das operárias permanecem constantemente inativas (não engajadas em nenhuma tarefa e sem exibir atividade ou movimentação corpórea). Ainda não existe dados o suficiente para argumentar qual seria a função de operarias inativas em uma colônia. Entretanto, os resultados são consistentes e não devem ser desconsiderados (CHARBONNEAU \& DORNHAUS, 2015; CHARBONNEAU et al., 2015). É possível que as saúvas observadas na trilha sem carregar folhas pertençam a um grupo de formigas inativas no que diz respeito ao engajamento em uma tarefa, mas que 
continuam exibindo atividade de deslocamento. Entretanto, dada a proporção de transportadoras/não-transportadoras, esse não parece ser o cenário mais explicativo.

Os resultados aqui apresentados mostram alta proporção de formigas na trilha não engajadas na tarefa de transporte. Obviamente que as formigas observadas na trilha podem ter se deslocado para a área de forrageamento, cortado fragmentos de folhas (o que caracterizaria engajamento em uma tarefa) e depois retornado sem transportar. Tal cenário é consistente com um fenômeno já descrito em saúvas, chamado de particionamento de tarefas. Por esse mecanismo, uma determinada tarefa, como a coleta de alimento, é particionada em várias etapas e dividida entre vários indivíduos. Já foi discutido que essa estratégia poderia aumentar a eficiência no desempenho da tarefa, pois os indivíduos engajados nas subtarefas se especializariam e se tornariam mais eficientes (HART et al., 2002; ARRUDA et al, 2016). Porém, esse cenário não parece realista, porque, como mostram os resultados, não são as mesmas formigas que continuamente transportam os fragmento de folha, o que derruba a premissa da especialização.

A ideia de que as formigas buscam folhas para alimentar o fungo simbionte e então se alimentar do fungo, apesar de verdadeira, não é inteiramente correta. Estudos realizados acerca da nutrição das formigas indicam que a dieta das formigas cortadeiras é mais complexa que isso. De fato as hifas do fungo simbionte correspondem a uma proporção grande da dieta e é a principal fonte de proteínas, principalmente para as larvas, que estão em fase de crescimento. Entretanto, para as formigas adultas, o carboidrato é o nutriente primordial. É o que mostram as curvas de sobrevivência de formigas adultas mantidas com alimentações de diferentes categorias nutricionais (SILVA et al., 2003). Argumenta-se que existe a possibilidade de que essas formigas que foram observadas na trilha, mas que não coletaram folhas, tenham se deslocado até a bandeja de alimentação em busca dos carboidratos que são exsudados pelos tecidos vegetais quando cortados. Nesse contexto, as formigas coletariam apenas uma parcela dos recursos vegetais cortados suficientes para a manutenção da homeostase nutricional do fungo simbionte; o que explicaria a baixa proporção de transportadoras/não-transportadoras. Isso faz sentido, uma vez que as formigas são capazes de detectar o estado do fungo que elas cultivam. As outras formigas adultas se deslocariam para a área de forrageamento com o objetivo de coletar carboidratos a fim de sanar suas próprias necessidades nutricionais. 
Essa análise de que o transporte de folhas não é eficiente parte do pressuposto de que todas as formigas que saem da colônia devem buscar o alimento. Entretanto, isso não necessariamente é verdade. O modelo de "foraging for work" (forrageando por tarefas) declara que indivíduos pertencentes a uma sociedade se alocam em suas tarefas conforme as necessidades vão aparecendo (FRANKS \& TOFTS, 1994). Caso os estímulos locais não sejam o suficiente para um individuo se engajar em uma tarefa ele muda de posição como se estivesse buscando uma tarefa para realizar. No caso do experimento aqui apresentado, os resultados demonstram que as demandas pelas tarefas permaneceram as mesmas ao longo do tempo. Se os estímulos dentro e fora da colônia permaneceram constantes e insuficientes, faz sentido, do ponto de vista do modelo de "foraging for work", que várias formigas tenham percorrido a trilha em busca de uma tarefa para se engajar e não tenham encontrado.

Mesmo que o modelo de "foraging for work" explique a grande quantidade de formigas na trilha não engajadas em nenhuma tarefa, ele não exclui a existência dos dois grupos de formigas observados: noturnas e diurnas. A busca ativa por uma tarefa na qual se engajar requer que a formiga esteja em sua fase de atividade. Caso ela esteja em sua fase de repouso, não haverá busca por nenhuma atividade.

\subsection{Morfometria das formigas nas diferentes fases}

As análises de tamanho mostram que as formigas que são observadas durante o dia são significativamente maiores que as formigas que forrageiam durante a noite (figura 24). Esses resultados indicam que de fato existe uma diferença mensurável, além do comportamento, entre as formigas que forrageiam nas diferentes fases. O que corrobora a hipótese de que existem dois grupos de formigas presentes na mesma colônia que forrageiam em fases diferentes.

O tamanho das formigas observadas em A e B é o mesmo e é significativamente maior que o tamanho das formigas em C e D (figura 25). Note que não existe diferença no tamanho das formigas em turnos da mesma fase. Isso significa que o fator que melhor explica a variação no tamanho das formigas que percorrem a trilha é de fato a condição de iluminação.

Em Atta sexdens, a morfologia das formigas parece explicar com consistência 
como ocorre o processo de divisão de tarefas. Nessa espécie, que apresenta um alto grau de polimorfismo, formigas de diferentes tamanhos realizam tarefas diferentes na colônia. Mais do que um simples correlato entre forma e função, é sabido que a morfologia implica em diferenças no desempenho das tarefas. Formigas forrageadoras, por exemplo, são maiores e capazes de carregar mais material vegetal proporcionalmente às formigas enfermeiras, por unidade de gasto energético. Dessa forma, a divisão de tarefas entre as operárias ocorre de maneira a diminuir os gastos energéticos da colônia (WILSON, 1980a, 1980b, 1983a, 1983b).

O tamanho do corpo também influência em como os animais se relacionam com o ambiente. Principalmente entre os insetos indivíduos maiores possuem maior resistência ao calor e à dissecação do que indivíduos menores (RIBEIRO et al., 2012).

Analisando pela perspectiva da relação do tamanho das operarias com a temperatura critica máxima e com o comportamento, é razoável argumentar que as formigas maiores forrageiem durante o dia e formigas menores durante a noite. Isso porque as formigas maiores possuiriam maior resistência à temperatura e à dissecação e, portanto, suportariam as condições ambientais durante o dia. Já as formigas menores, cuja resistência é menor, seriam observadas durante a noite, quando as condições ambientais são mais amenas.

Essa relação das formigas com as condições ambientes já foi descrita e discutida na tabela 1 para as variações sazonais. Entretanto, variações de temperatura e umidade relativa do ar ocorrem de maneira similar na escala diária. Faz sentido que, se a tarefa de forrageamento é realizada tanto de dia quanto de noite (com preferência pela noite), as formigas que são responsáveis por essa tarefa, dividam-se de forma a maximizar o potencial coletivo de coleta de recursos. Já que existem formigas com diferentes graus de resistência térmica, aquelas que são mais resistentes forrageiam nas condições mais extremas e as menos resistentes forrageiam na condição mais amena. Vale ressaltar que essa diferença morfológica encontrada em formigas de dia e formigas de noite suportam a ideia de que existem duas castas temporais nas saúvas.

O polimorfismo das saúvas vai além do tamanho do corpo. Algumas estruturas anatômicas não variam com a mesma razão do tamanho do corpo, ou seja, são alométricas. Soldados, por exemplo, possuem mandíbulas muito maiores do que enfermeiras, dadas as devidas proporções. Já foi discutido que essa alometria 
observada teria papel importante na organização social das formigas. Uma estrutura anatômica cuja alometria influência na relação que os indivíduos resguardam com o ambiente é o olho. Formigas do gênero Myrmica de diferentes castas (machos alados, fêmeas virgens e operárias) apresentam fases diferentes de atividade. Foram descritas variações no olho de indivíduos dessas castas que são explicadas pela fase de atividade preferencial de cada casta e não pela variação do tamanho. Fêmeas virgens e machos alados, por exemplo, possuem olhos (área total), omatídeos e ocelos maiores proporcionalmente que operárias. Por sua vez, as formas reprodutivas apresentam fase de atividade durante o claro, enquanto que as operárias são ativas durante o escuro. Os autores discutem que essa alometria seria uma especialização intraespecífica ao ambiente ( MOSER et al., 2004; NARENDRA et al., 2012; YILMAZ et al., 2014). Tal fenômeno poderia ocorrer de maneira similar entre as castas de operárias de saúvas, cujo polimorfismo é maior que o observado em Myrmica.

Nesse cenário, a divisão temporal de tarefas por formigas de morfologias diferentes permite o contínuo forrageamento ao longo do dia inteiro. Portanto, esse seria mais um mecanismo que aumenta os ganhos da colônia em relação à aquisição de alimentos. Faz sentido que essas variações morfológicas e esse mecanismo tenham sido de alguma forma selecionados ao longo do tempo.

\subsection{Formigas diferentes nas diferentes fases}

Além do tamanho do corpo, quais poderiam ser as outras diferenças entre esses dois grupos de formigas? O que eles possuem de diferente entre si para que a relação das operárias com o ritmo de claro e escuro seja diferente?

As colônias de saúvas são monogínicas, ou seja, possuem apenas uma única rainha. Entretanto, essa rainha copula com vários machos durante o voo nupcial. Ou seja, apesar de todas as operárias serem irmãs, existem linhagens paternais diferentes dentro de uma mesma colônia. Em formigas Acromyrmex echinator, que também são formigas cortadeiras e apresentam diversas semelhanças à Atta sexdens, a linhagem paternal é determinante para a diferenciação morfológica das operárias. Por consequência, as linhagens paternais são determinantes para definir a qual tarefa uma determinada operária será designada ao longo da vida (HUGHES, et al. 2003), dadas as regras e mecanismos de divisão de tarefas. Tal padrão observado em A. echinator 
poderia existir também em A. sexdens.

No caso especifico das saúvas, a linhagem paternal diferente poderia explicar a grande variação morfológica observada na colônia. Consequentemente, explicaria a divisão temporal de tarefas relatadas neste trabalho, uma vez que existe forte relação entre o tamanho das formigas e a fase de preferência de forrageio. Contudo, a linhagem paternal pode influenciar em outras características além do tamanho, afinal, a carga genética proveniente do macho corresponde à metade do genótipo das operárias.

Uma dessas características pode ser justamente a fase de atividade preferencial. Em Apis mellifera foi descrito que a linhagem paternal apresenta correlação com a fase de forrageamento preferencial de operárias. No caso das abelhas o forrageamento acontece durante a fase de claro apenas. Isso porque as abelhas dependem muito da luz para a navegação espacial. Mas as abelhas que saem para forragear no turno da manhã são diferentes das abelhas que saem para forragear no turno da tarde. As abelhas melíferas não apresentam polimorfismo entre as operárias, como o observado nas saúvas, a diferença entre as abelhas que forrageiam de manhã e as abelhas que forrageiam a tarde é a linhagem paternal a qual elas pertencem (KRAUS et al., 2011). Em outras palavras, é seguro afirmar que de alguma forma o genótipo intrínseco de cada operária influencia na maneira com a qual ela se relaciona com os ciclos ambientais.

Apesar da existência dessa correlação, os mecanismos pelo qual os diferentes genótipos influenciam no comportamento de forrageamento continuam desconhecidos. Uma possibilidade que poderia diferenciar essas formigas diz respeito à aferência da informação da condição de luminosidade do ambiente. Como discutido na seção anterior, algumas estruturas anatômicas não apresentam a mesma curva de crescimento do resto do corpo. O olho pode ser uma dessas estruturas. Consequentemente, a maneira como o olho e suas estruturas fotorreceptoras codificam a informação acerca da condição de iluminação pode variar entre formigas de diferentes tamanhos/genótipos.

Outra possibilidade diz respeito à eferências diferentes à informação dada pelo oscilador molecular. Isso faria com que diferentes operárias respondessem de maneira diferente ao ritmo ambiental de claro e escuro. Ou mesmo, em um caso mais extremo, o oscilador endógeno poderia funcionar de maneira diferente nas diferentes formigas. 
Entretanto, os mecanismos moleculares do oscilador endógeno são muito conservados através das linhagens, portanto, esse segundo cenário parece mais improvável.

Como apresentado na introdução, todos os animais apresentam algum tipo de oscilador endógeno passível de ser sincronizado com os ritmos ambientais. No caso dos insetos a maquinaria molecular do oscilador é baseada nas alças de retroalimentação da expressão dos genes period/timeless e clock/cycle. Essas alças se autorregulam criando um ciclo constante de aproximadamente 24 horas. Independente do habito de vida do inseto, seja ele noturno ou diurno, o gene period tem pico de expressão no meio da noite (SANDRELLI et al., 2008). Ou seja, o hábito de vida do animal (i.e. noturno ou diurno) depende da eferência dada ao estimulo da expressão dos genes do relógio. É possível que dentro de uma mesma colônia existam indivíduos que respondem de maneira diferente a esse estimulo, gerando os grupos noturnos e diurnos simultaneamente. De maneira semelhante ao observado em Apis mellifera.

Tanto a hipótese de diferenças no padrão de expressão dos genes do relógio quando nas diferenças de codificação da informação luminosa pelo olho e as estruturas fotorreceptoras das formigas precisam ser testadas.

A ideia de que essas formigas sejam diferentes entre si compactua com os modelos de limiares. Nas possibilidades levantadas acima os limiares de resposta à informação luminosa seriam diferentes, o que gerariam padrões comportamentais de forrageamento diferentes. Além disso, as diferenças nos limiares seriam em função de diferenças na relação que os indivíduos têm com a informação dada pelo relógio molecular, ou em função das diferenças na estrutura do olho das diferentes castas. Note que as diferenças dos limiares apresentadas seriam exclusivamente dadas por fatores internos aos indivíduos. Como fatores externos também podem gerar diferenças nos limiares, não se descarta a possibilidade de que as formigas dividam a tarefa temporalmente em função de algum aspecto externo ao individuo.

Apesar das hipóteses acima serem promissoras, não é possível descartar a hipótese que as formigas que aparecem em diferentes horários sejam iguais. Nesse caso, resta tentar compreender quais processos coletivos que podem gerar esse padrão observado. Entretanto, como a diferença morfológica foi observada, é razoável pensar que essas formigas que dividem temporalmente a tarefa de forrageamento são de fato diferentes entre si. 


\subsection{Organização temporal coletiva das formigas}

Enquanto a colônia apresenta maior atividade na fase de escuro, nem todos os indivíduos seguem esse mesmo padrão. Os resultados apontam a existência de um grupo de formigas que são diurnas coexistindo com formigas noturnas. Além disso, foi descrita a diferença morfológica entre esses dois grupos de formigas e foram levantadas várias hipóteses sobre as possíveis diferenças que essas operárias podem apresentar, do ponto de vista fisiológico, para que elas se relacionem de maneira diferente com as condições ambientais. Resta saber como essas diferenças são integradas para gerar o padrão coletivo observado na colônia.

O modelo de auto-organização talvez seja a melhor solução para essa questão. Como citado anteriormente, sistemas auto organizados não apresentam comando hierárquico ou seguem algum tipo de modelo para gerar padrões complexos. Os padrões complexos observados são decorrentes da interação das partes que compõe o nível inferior do sistema. O padrão coletivo diz respeito à colônia de saúva ser noturna, ou seja, apresentar maior atividade coletiva na fase de escuro. As partes do nível inferior desse sistema são as operárias.

Independente da diferença entre as operárias sejam elas: (1) resistência diferencial às condições ambientais dada pela morfologia; (2) diferenças genéticas no comportamento dada a linhagem paternal; (3) diferenças na morfologia do olho e na aferência dos sinais visuais; ou (4) diferenças na eferência do sinal codificado pelo oscilador endógeno; as formigas acabam por se organizar dessa forma. Formigas diurnas forrageiam na fase de claro e formigas noturnas forrageiam na fase de escuro. Qualquer uma das possibilidades levantadas acima pode ser a regra pela qual os indivíduos interagem gerando o padrão coletivo. Se quaisquer umas das possibilidades ocorrem, ou mesmo mais de uma, naturalmente as formigas irão se diferenciar nos grupos aqui observados. De qualquer forma, a auto-organização continua sendo um ótimo modelo para explicar o comportamento de sistemas coletivos. Resta agora descobrir dentre as possibilidades discutidas acima quais são as regras adjacentes ao sistema. 


\subsection{Transposição do modelo de abelhas para formigas}

As abelhas são insetos eussociais assim como as formigas. Existem diversas semelhanças na organização social desses dois grupos. Não obstante, abelhas e formigas pertencem à ordem Hymenoptera, o que significa que esses grupos são próximos do ponto de vista filogenético. Por mais que abelhas e formigas tenham divergido a aproximadamente 160 milhões de anos atrás, é seguro afirmar que os mecanismos moleculares e fisiologia são muito semelhantes. De fato, as abelhas são consideradas organismos modelo no estudo da sociobiologia e ecologia comportamental de insetos eussociais. Não obstante, o conhecimento acumulado sobre a biologia das abelhas, especialmente a Apis mellifera, é extenso. Todo o genoma dessa espécie está sequenciado e existem diversos estudos sobre a genética comportamental dessa espécie. Além disso, essa espécie é de interesse econômico por ser protagonista na produção de mel e na polinização de inúmeras espécies vegetais.

Por mais semelhantes que os dois sistemas sejam, ainda assim existem algumas diferenças que são significativas e dizem respeito à história evolutiva de cada grupo. As estratégias de forrageamento empregadas por esses dois grupos é um exemplo. A maioria das espécies de abelhas forrageia em recursos florais. Existe uma busca ativa pelas flores que apresentem o melhor recurso alimentar. Portanto, o sistema visual das abelhas é muito desenvolvido. Formigas, por outro lado, tendem a apresentar um hábito alimentar coletor (seja de presas, seja de recursos vegetais). Aparentemente, esse hábito não requer um sistema visual muito desenvolvido. Tanto que várias espécies nem apresentam olhos funcionais.

Essas características geram uma diferença na relação que os diferentes grupos têm com os ritmos ambientais. Enquanto abelhas são exclusivamente diurnas, pois dependem da visão para a coleta do recurso alimentar; diversas espécies de formigas são noturnas. Tanto abelhas quanto formigas são animais eussociais que formam colônias e dividem tarefas reprodutivas e de manutenção da sociedade. A análise do padrão de atividade dessas espécies necessita levar esse aspecto social em consideração.

A divisão de tarefas, e os padrões de atividade, em abelhas estão fortemente relacionados com a casta (i.e. rainha ou operária) e com a idade das operárias. A tarefa primordial da rainha é a deposição de ovos. Tal tarefa é realizada constantemente e 
sem ritmo pela rainha. A deposição de ovos é continua. Operárias mais novas tendem a permanecer dentro da colônia e cuidar dos ovos, larvas e rainha. A demanda por essa tarefa é constante e, a realização dela pelas operárias também. Vale ressaltar que essas tarefas são realizadas exclusivamente dentro das colônias e que, portanto, não há contato desses indivíduos com os ritmos ambientais. Abelhas mais velhas trocam de tarefa e passam a ficar encarregadas pelo forrageamento. A tarefa de forrageamento, por sua vez, é realizada por abelhas cuja atividade é rítmica. Essas abelhas mais velhas forrageiam durante o dia e repousam durante a noite. Existe, portanto, ontogenia dos ritmos de atividade por parte das abelhas. É curioso notar que as abelhas que são expostas ao ritmo ambiental de claro e escuro desenvolvem ritmo, enquanto que aquelas que permanecem em condições constantes continuam arrítmicas. Note, portanto, que a ontogenia da ritmicidade em abelhas está diretamente relacionada à exposição aos ritmos ambientais (TOMA et al., 2000; BLOCH et al, 2001, 2002).

Os resultados aqui apresentados demonstram um padrão de atividade ligeiramente diferente. Apesar de não se conhecer a idade das formigas analisadas, é seguro afirmar que existem dois grupos de operárias: diurnas e noturnas. Ou seja, de maneira semelhante em abelhas, existem dois grupos que se relacionam de maneira diferente com o ritmo ambiental. Mas ao contrário das abelhas, ambos os grupos de saúvas estão submetidos ao ritmo ambiental. Portanto, não é a ontogenia do ritmo de atividade em função do ritmo ambiental que explica a existência desses dois grupos.

Os mecanismos do relógio biológico de abelha já estão bem descritos. De fato, as abelhas mais jovens eclodem sem a ritmicidade do oscilador molecular consolidada. Com o passar do tempo a ritmicidade molecular começa a emergir e as abelhas passam a apresentar ritmicidade na atividade, concomitantemente à troca de tarefa. Quatro são os genes do relógio em abelhas que apresentam variação circadiana na expressão. São eles: Cycle, clock, period e Cryptochrome. Investigar como ocorre a expressão desses genes nos cérebros das formigas pode auxiliar na compreensão de como esse padrão de divisão temporal de tarefas pode surgir do ponto de vista fisiológico.

Como citado anteriormente, o modelo de abelhas e formigas são similares em diversos aspectos. Entretanto, existe o potencial para que os mecanismos moleculares do oscilador apresentem diferenças. Todas as abelhas de uma colmeia, se submetidas ao ritmo ambiental, são rítmicas e diurnas. Nas formigas submetidas ao ritmo ambiental, algumas são noturnas e outras são diurnas. Quais mecanismos moleculares e 
fisiológicos que podem gerar esse padrão? Essa é uma questão ainda a ser respondida.

\subsection{Colônia como superorganismo}

As primeiras denominações de colônias de insetos eussociais surgiram do contexto reprodutivo. Isso porque, do ponto de vista evolutivo, é um desafio compreender a existência de um sistema de vários indivíduos, no qual a maioria não se reproduzia diretamente. Discutia-se a existência de um altruísmo genuíno no qual as operárias abdicavam da capacidade de reprodução em detrimento da rainha. Argumentou-se, portanto, que a unidade evolutiva dos insetos eussociais seria a colônia inteira e não cada indivíduo. Estabeleceu-se uma analogia com os outros organismos: as rainhas, que são as únicas a se reproduzir, seriam equivalentes à linhagem germinativa de células, enquanto as operárias seriam análogas à linhagem somática. Dessa forma, toda a colônia seria um superorganismo composto de vários indivíduos (WILSON \& SOBER, 1989).

Conforme os estudos foram avançando, essa abordagem tornou-se menos comum. Isso porque passaram a ser estudados os processos evolutivos que poderiam dar origem a esse tipo de organização social. Com o advento das ideias de fitness inclusivo de Hamilton (1964) e da nova síntese da biologia evolutiva, um modelo baseado na seleção dos indivíduos surgiu. Dessa forma, as colônias de insetos eussociais não consistiam mais em um desafio à seleção natural. Portanto, a ideia de que a unidade evolutiva de insetos eussociais fosse a colônia perdeu força e suporte.

De fato é inegável que existem vários modelos evolutivos consistentes que mostram que a evolução das organizações eussociais é completamente plausível do ponto de vista da nova síntese da biologia evolutiva (NOWAK et al., 2010). Portanto, argumentar que colônias de insetos eussociais corresponde a um superorganismo, da maneira e no contexto no qual o termo foi cunhado não faz mais sentido.

Por outro lado, o estudo dos mecanismos e estratégias de integração e coordenação dos indivíduos pertencentes a uma colônia demonstram um vasto nível de complexidade. Cada vez mais nota-se que a complexidade de cada indivíduo só faz sentido quando analisada do ponto de vista social. As teorias dos limiares e os diversos estudos em genética comportamental demonstram que para a compreensão dos padrões 
coletivos é necessário conhecer as características das unidades que formam o sistema. A própria ideia de aplicar os conceitos de auto-organização nos sistemas biológicos sociais demonstra que existem dois níveis de organização fortemente dependentes: o individual e o coletivo.

As premissas do modelo de auto organização ditam que os padrões complexos são decorrentes das interações dos componentes do nível hierárquico inferior sem a pressão de um agente externo (CAMAZINE, 2003). Note que nos insetos eussociais, diversos dos comportamentos coletivos observáveis podem ser explicados com base no modelo de auto-organização. Inclusive, algumas das propriedades coletivas que emergem da interação dos indivíduos dizem respeito à homeostase das condições internas da colônia. Inclusive os resultados aqui apresentados demostram essa fenômeno. A colônia de saúvas como um todo é noturna, pois durante a noite é quando se observa a maior atividade dos indivíduos na trilha. Entretanto, essa representação coletiva não encontra total respaldo no nível de analise individual. Como os resultados mostram, existem indivíduos que são noturnos, mas também existem indivíduos que são diurnos. Da interação entre esses diferentes grupos de formigas surge o padrão coletivo observado na colônia.

Obviamente que esses diferentes níveis de analise possuem suas particularidades e são relativamente independentes. Do ponto de vista individual, cada operária possui uma fisiologia própria; do ponto de vista coletivo, a colônia apresenta estratégias e mecanismos de integração e informação. 


\section{Conclusão}

O trabalho apresentado descreveu com bastante consistência a relação entre os ritmos de atividade coletiva e a divisão temporal de tarefas. Mais especificamente a existência de dois grupos distintos de formigas cujas fases de atividades preferenciais são opostas. Dentro de uma colônia de Atta sexdens rubropilosa existem operárias que forrageiam preferencialmente na fase de claro e formigas que forrageiam na fase de escuro. Tal organização coletiva encontra corroboração na morfologia das formigas pertencentes à esses grupos distintos: formigas de claro são maiores que formigas de escuro. Além disso, essa organização coletiva traz implicações para a eficiência de forrageamento: no claro a coleta de alimentos é maior proporcionalmente ao numero de formigas do que no escuro. No que diz respeito aos modelos que buscam explicar os comportamentos coletivos complexos observados em insetos eussociais, os resultados aqui apresentados entram em consonância com modelos de auto-organização e 'forging for work'. Entretanto, no que diz respeito aos modelos que descrevem a relação entre a fase preferencial de atividade e os ritmos ambientais em insetos eussociais, os resultados mostram um sistema ligeiramente diferente e que merece continuar sendo investigado. Principalmente levando em consideração as causas morfológicas, fisiológicas e moleculares que podem explicar essa diferença entre formigas de claro e formigas de escuro. 


\section{Referências}

ABBOT, P. et al. Inclusive fitness theory and eusociality. Nature, v. 471, n. 7339, p. E1-4-10, 24 mar. 2011.

AGRAWAL, A. A.; DUBIN-THALER, B. J. Induced responses to herbivory in the Neotropical ant-plant association between Azteca ants and Cecropia trees: response of ants to potential inducing cues. Behavioral Ecology and Sociobiology, v. 45, n. 1, p. 47-54, 14 jan. 1999.

ASCHOFF, J. Exogenous and endogenous components in circadian rhythms. Cold Spring Harbor symposia on quantitative biology, v. 25, p. 11-28, 1960.

AUTUORI, M. Investigação sobre a biologia da sauva. Ciência e Cultura, v. 1, n. 1-2, p. 4 13, 1950.

BACANDRITSOS, N. et al. Sudden deaths and colony population decline in Greek honey bee colonies. Journal of Invertebrate Pathology, v. 105, n. 3, p. 335-340, 2010.

BANKS, A. N.; SRYGLEY, R. B. Orientation by magnetic field in leaf-cutter ants, Atta colombica (Hymenoptera: Formicidae). Ethology, v. 109, n. 10, p. 835-846, 2003.

BESHERS, S. N.; FEWELL, J. H. MODELS OF DIVISION OF LABOR IN SOCIAL INSECTS. Annual Review of Entomology, v. 46, n. 1, p. 413-440, jan. 2001.

BLOCH, G.; SULLIVAN, J. P.; ROBINSON, G. E. Juvenile hormone and circadian locomotor activity in the honey bee Apis mellifera. J Insect Physiol, v. 48, p. 1123-1131, 2002.

BLOCH, G.; TOMA, D. P.; ROBINSON, G. E. Behavioral Rhythmicity , Age , Division of Labor and period Expression in the Honey Bee Brain. Journal of biological rhythms, v. 16, n. 5, p. 444-456, 2001.

BONABEAU, E. Fixed Response Thresholds and the Regulation of Division of Labor in Insect Societies. Bulletin of Mathematical Biology, v. 60, n. 4, p. 753-807, jul. 1998.

BONABEAU, E.; THERAULAZ, G.; DENEUBOURG, J.-L. Quantitative Study of the Fixed Threshold Model for the Regulation of Division of Labour in Insect Societies. Proceedings of the Royal Society B: Biological Sciences, v. 263, n. 1376, p. 1565-1569, 22 nov. 1996.

BOSSERT, W. H.; WILSON, E. O. The analysis of olfactory communication among animals. Journal of Theoretical Biology, v. 5, n. 3, p. 443-469, 1963.

BOUCHEBTI, S. et al. Contact rate modulates foraging efficiency in leaf cutting ants. Scientific Reports, v. 5, p. 18650, 21 dez. 2015.

BRISCOE, A. D.; CHITTKA, L. The Evolution of color vision in insects. Annual review of entomology, p. 471-510, 2001.

BUHR, E. D. et al. Neuropsin (OPN5)-mediated photoentrainment of local circadian oscillators in mammalian retina and cornea. Proceedings of the National Academy of Sciences, v. 112, n. 42, p. 13093-13098, 20 out. 2015.

BUZZI, Zundir José. Entomologia didática. In: Entomologia didática. UFPR, 2010.

CAMAZINE, S. Self-organizing pattern formation on the combs of honey bee colonies. Behavioral Ecology and Sociobiology, v. 28, n. 1, p. 61-76, jan. 1991.

CAMAZINE, Scott. Self-organization in biological systems. Princeton University Press, 2003.253 
CAMERON, S. A. et al. Patterns of widespread decline in North American bumble bees. Proceedings of the National Academy of Sciences, v. 108, n. 2, p. 662-667, 2011.

CHAPMAN, Reginald Frederick. The insects: structure and function. Cambridge university press, 1998.

CHARBONNEAU, D.; DORNHAUS, A. Workers "specialized" on inactivity: Behavioral consistency of inactive workers and their role in task allocation. Behavioral Ecology and Sociobiology, v. 69, n. 9, p. 1459-1472, 21 set. 2015.

CHARBONNEAU, D.; HILLIS, N.; DORNHAUS, A. "Lazy" in nature: ant colony time budgets show high "inactivity" in the field as well as in the lab. Insectes Sociaux, v. 62, n. 1, p. 31-35, 13 fev. 2015.

CHERRETT, J. M. THE FORAGING BEHAVIOUR OF ATTA CEPHALOTES L . Journal of Animal Ecology, v. 37, n. 2, p. 387-403, 1968. DEJEAN, A. et al. A cuckoo-like parasitic moth leads African weaver ant colonies to their ruin. Scientific Reports, v. 6, p. 23778, 2016.

CHONG, K. F.; LEE, C. Y. Influences of temperature, relative humidity and light intensity on the foraging activity of field populations of the longlegged ant, Anoplolepis gracilipes (hymenoptera: Formicidae). Sociobiology, v. 54, n. 2, p. 531-539, 2009.

CROS, S. et al. Spatial and temporal variations in the activity patterns of Mediterranean ant communities. Écoscience, v. 4, n. 3, p. 269-278, 1997. GOSS, S. et al. Self-organized shortcuts in the Argentine ant. Naturwissenschaften, v. 76, n. 12, p. 579-581, 1989.

CZACZKES, T. J.; GRÜTER, C.; RATNIEKS, F. L. W. Trail Pheromones, An integrative view of their role in social insect colony organization. Annual Review of Entomology, v. 60, 2015.

DARWIN, Charles; BYNUM, William F. The origin of species by means of natural selection: or, the preservation of favored races in the struggle for life. AL Burt, 2009.

DETRAIN, C.; PASTEELS, J. M. Caste differences in behavioral thresholds as a basis for polyethism during food recruitment in the ant, Pheidole pallidula (Nyl.) (Hymenoptera: Myrmicinae). Journal of Insect Behavior, v. 4, n. 2, p. 157-176, 1991.

DOBSON, H. E. M.; DANIELSON, E. M.; VAN WESEP, I. D. Pollen odor chemicals as modulators of bumble bee foraging on Rosa rugosa Thunb. (Rosaceae). Plant Species Biology, v. 14, n. 2, p. 153-166, 1999. RIBEIRO, P. L.; CAMACHO, A.;

DUFFY, J. E.; MORRISON, C. L.; RÍOS, R. Multiple origins of eusociality among spongedwelling shrimps (Synalpheus). Evolution; international journal of organic evolution, v. 54, n. 2, p. 503-516, 2000.

DUNLAP, Jay C.; LOROS, Jennifer J.; DECOURSEY, Patricia J. Chronobiology: biological timekeeping. Sinauer Associates, 2004.

DUSSUTOUR, A. et al. Crowding increases foraging efficiency in the leaf-cutting ant Atta colombica. Insectes Sociaux, v. 54, n. 2, p. 158-165, 2007.

ECKERT, Roger et al. Animal physiology: mechanisms and adaptations. WH Freeman \& Co., 1988.

ELIZALDE, L.; FARJI-BRENER, A. To be or not to be faithful: flexible fidelity to foraging trails in the leaf-cutting ant Acromyrmex lobicornis. Ecological Entomology, v. 37, n. 5, p. 370-376, 26 out. 2012.

ELLIS, J. D.; EVANS, J. D.; PETTIS, J. Colony losses, managed colony population decline, and Colony Collapse Disorder in the United States. Journal of Apicultural Research, v. 49, n. 1, p. 134-136, 2010. 
EMERY, P. et al. CRY, a Drosophila Clock and Light-Regulated Cryptochrome, Is a Major Contributor to Circadian Rhythm Resetting and Photosensitivity. Cell, v. 95, n. 5, p. 669-679, 1998.

FEWELL, J. H.; PAGE JR, R. E. Colony-level selection effects on individual and colony foraging task performance in honeybees, Apis mellifera L. Behavioral Ecology and Sociobiology, v. 48, n. 3, p. 173-181, 24 ago. 2000.

FOWLER, H. G.; ROBINSON, S. W. Foraging by Atta sexdens (Formicidae: Attini): seasonal patterns, caste and efficiency. Ecol. Entomol., v. 4, p. 239-247, 1979.

FRANKS, N. R.; TOFTS, C. Foraging for work: how tasks allocate workers. Animal Behaviour, v. 48, n. 2, p. 470-472, ago. 1994.

FRISCH, K.; JANDER, R. Uber den Schwanzeltanz der Bienen. Zeitschrift fur Vergleichende Physiologie, v. 40, n. 3, p. 239-263, 1957.

GIURFA, M. Cognition with few neurons: Higher-order learning in insects. Trends in Neurosciences, v. 36, n. 5, p. 285-294, 2013.

HAMILTON, W. D. The genetical evolution of social behaviour. I. Journal of Theoretical Biology, v. 7, n. 1, p. 1-16, jul. 1964.

HARDIN, P. E. Molecular genetic analysis of circadian timekeeping in Drosophila. [s.l: s.n.]. v. 74

HARDIN, P. E.; HALL, J. C.; ROSBASH, M. Feedback of the Drosophila period gene product on circadian cycling of its messenger RNA levels. Nature, v. 343, n. 6258, p. 536-540, 1990.

HART, A. G.; ANDERSON, C.; RATNIEKS, F. L. W. Task partitioning in leafcutting ants. Acta Ethologica, v. 5, n. 1, p. 1-11, 2002.

HART, A. G.; RATNIEKS, F. L. W. Leaf caching in the leafcutting ant Atta colombica: organizational shift, task partitioning and making the best of a bad job. Animal Behaviour, v. 62, n. 2, p. 227-234, ago. 2001.

HART, A. G.; RATNIEKS, F. L. W. Waste management in the leaf-cutting ant Atta colombica. Behavioral Ecology , v. 13, n. 2, p. 224-231, 2002.

HART, A.; RATNIEKS, F. Leaf caching in Atta leafcutting ants: discrete cache formation through positive feedback. Animal behaviour, v. 59, n. 3, p. 587-591, 2000.

HARVELL, C. D. The Evolution Of Polymorphism in Colonial Invertebrates and Social Insects. The Quarterly Review of Biology, v. 69, n. 2, p. 155-185, 1994.

HÖLLDOBLER, Bert; WILSON, Edward O. The ants. Harvard University Press, 1990.

HOWARD, J. J. Costs of trail construction and maintenance in the leaf-cutting ant Atta columbica. Behavioral Ecology and Sociobiology, v. 49, n. 5, p. 348-356, 2001.

HUGHES, W. O. H. et al. Worker caste polymorphism has a genetic basis in Acromyrmex leaf-cutting ants. Proceedings of the National Academy of Sciences of the United States of America, v. 100, n. 16, p. 9394-9397, 2003.

INGRAM, C. M. et al. Challenging the Inbreeding Hypothesis in a Eusocial Mammal: Population Genetics of the Naked Mole-rat, Heterocephalus glaber. Molecular Ecology, p. n/a-n/a, 2015. NAUG, D. Structure and resilience of the social network in an insect colony as a function of colony size. Behavioral Ecology and Sociobiology, v. 63, n. 7, p. 1023-1028, 2 abr. 2009.

JANDT, J. M.; DORNHAUS, A. Bumblebee response thresholds and body size: does worker 
diversity increase colony performance? Animal Behaviour, v. 87, p. 97-106, jan. 2014.

JEANNE, R. L. Division of labor is not a process or a misleading concept. Behavioral Ecology and Sociobiology, p. 1109-1112, 2016.

JOHNSON, B. R.; LINKSVAYER, T. A. Deconstructing the Superorganism: Social Physiology, Groundplans, and Sociogenomics. The Quarterly Review of Biology, v. 85, n. 1, p. 57-79, mar. 2010.

KNADEN, M.; GRAHAM, P. The Sensory Ecology of Ant Navigation: From Natural Environments to Neural Mechanisms. Annual Review of Entomology, v. 61, n. 1, p. annurevento-010715-023703, 2016.

KRAUS, B F.; GERECKE, E.; MORITZ, R. F. A. Shift work has a genetic basis in honeybee pollen foragers (Apis mellifera L.). Behavior Genetics, v. 41, n. 2, p. 323-328, 2011.

LEWIS, T.; POLLARD, G. V.; DIBLEY, G. C. Rhythmic Foraging in the Leaf-Cutting Ant Atta cephalotes (L.) (Formicidae: Attini). The Journal of Animal Ecology, v. 43, n. 1, p. 129, fev. 1974.

LONE, S. R.; CHAKRAVARTHI, A.; SHARMA, V. K. Sex and age related changes in the locomotor activity and phototactic behaviors of two closely related species of Camponotus ants. Journal of Insect Physiology, v. 58, n. 1, p. 75-82, 2012.

LONE, S. R.; SHARMA, V. K. Timekeeping through social contacts: social synchronization of circadian locomotor activity rhythm in the carpenter ant Camponotus paria. Chronobiology international, v. 28, n. 10, p. 862-72, dez. 2011.

LOPES, P., RIBEIRO, P. L., HELENE. A. F., Metric Relations Between Body Parts In Atta sexdens rubropilosa. In: XXI Simpósio Internacional de Mirmecologia, 2013, Fortaleza. Anais...Fortaleza, UECE, 2013, p 250-

MARQUES, Nelson. Cronobiologia: Princípios e Aplicacões (revista e ampliada) Vol. 12. Edusp, 1997.

MERSCH, D. P.; CRESPI, A.; KELLER, L. Tracking Individuals Shows Spatial Fidelity Is a Key Regulator of Ant Social Organization. Science, v. 340, n. 6136, p. 1090-1093, 31 maio 2013.

MOSER, J. C. et al. Eye size and behaviour of day- and night-flying leafcutting ant alates. Journal of Zoology, v. 264, p. 69-75, 2004.

NARENDRA, A. et al. Caste-specific visual adaptations to distinct daily activity schedules in Australian Myrmecia ants. Proceedings. Biological sciences / The Royal Society, v. 278, n. 1709, p. 1141-9, 22 abr. 2011.

NATION, James L. Insect physiology and biochemistry. CRC press, 2008.

NICHOLAS, L.; CALDERONE, W. Proximate mechanisms of age polyethism in the honey bee, Apis mellifera. Apidologie, v. 29, n. 1, p. 127-158, 1998.

NICKELE, M. A. et al. Daily foraging activity of Acromyrmex (Hymenoptera: Formicidae) leaf-cutting ants. Sociobiology, v. 63, n. 1, p. 645-650, 2016.

NOWAK, M. A; TARNITA, C. E.; WILSON, E. O. The evolution of eusociality. Nature, v. 466, n. 7310, p. 1057-1062, 26 ago. 2010.

ORR, A. G.; CHARLES, J. K. Foraging in the giant forest ant, camponotus gigas (Smith) (Hymenoptera: Formicidae): Evidence for temporal and spatial specialization in foraging activity. Journal of Natural History, v. 28, n. 4, p. 861-872, 1994. 
PACALA, S. W.; GORDON, D. M.; GODFRAY, H. C. J. Effects of social group size on information transfer and task allocation. Evolutionary Ecology, v. 10, n. 2, p. 127-165, mar. 1996.

PLAUTZ, J. D. Independent Photoreceptive Circadian Clocks Throughout Drosophila. Science, v. 278, n. 5343, p. 1632-1635, 1997.

POWELL, S. How ecology shapes caste evolution: Linking resource use, morphology, performance and fitness in a superorganism. Journal of Evolutionary Biology, v. 22, n. 5, p. 1004-1013, 2009.

REHAN, S. M.; TOTH, A. L. Climbing the social ladder: The molecular evolution of sociality. Trends in Ecology and Evolution, v. 30, n. 7, p. 426-433, 2015.

RIBEIRO, P. L.; CAMACHO, A.; NAVAS, C. A. Considerations for Assessing Maximum Critical Temperatures in Small Ectothermic Animals: Insights from Leaf-Cutting Ants. PLoS ONE, v. 7, n. 2, p. e32083, 24 fev. 2012.

ROCES, F. Individual complexity and self-organization in foraging by leaf-cutting ants. Biology Bulletin, v. 202, n. 3, p. 306-13, jun. 2002.

SCHMIDT-NIELSEN, Knut. Fisiologia Animal: Adaptação E Meio Ambiente . Grupo GenLivraria Santos Editora Ltda., 2000.

SCHWANDER, T.; ROSSET, H.; CHAPUISAT, M. Division of labour and worker size polymorphism in ant colonies: the impact of social and genetic factors. Behavioral Ecology and Sociobiology, v. 59, n. 2, p. 215-221, 29 dez. 2005.

SHARMA, V. K. et al. Circadian consequences of social organization in the ant species Camponotus compressus. Naturwissenschaften, v. 91, n. 8, p. 386-390, 2004.

SHARMA, V. K. et al. Possible evidence for shift work schedules in the media workers of the ant species Camponotus compressus. Chronobiology international, v. 21, n. 2, p. 297-308, 2004.

SILVA, A. et al. Survival of Atta sexdens workers on different food sources. Journal of Insect Physiology, v. 49, n. 4, p. 307-313, abr. 2003.

THERAULAZ, G.; BONABEAU, E.; DENEUBOURG, J. Response threshold reinforcements and division of labour in insect societies. Proceedings of the Royal Society B: Biological Sciences, v. 265, n. 1393, p. 327-332, 1998.

TOLEDO, M. A. DE et al. Two castes sizes of leafcutter ants in task partitioning in foraging activity. Ciência Rural, v. 46, n. 11, p. 1902-1908, nov. 2016.

TOMA, D. P. et al. Changes in period mRNA levels in the brain and division of labor in honey bee colonies. Proceedings of the National Academy of Sciences of the United States of America, v. 97, n. 12, p. 6914-6919, 2000.

TRIBLE, W. et al. orco Mutagenesis Causes Loss of Antennal Lobe Glomeruli and Impaired Social Behavior in Ants. Cell, v. 170, n. 4, p. 727-735.e10, ago. 2017.

VILELA, E. F.; JAFFÉ, K.; HOWSE, P. E. Orientation in leaf-cutting ants (Formicidae: Attini). Animal Behaviour, v. 35, p. 1443-1453, 1987.

VON THIENEN, W.; METZLER, D.; WITTE, V. How memory and motivation modulate the responses to trail pheromones in three ant species. Behavioral Ecology and Sociobiology, p. 393-407, 2016.

WEBER, A. The Fungus-Culturing Behavior of Ants. American zoologist, v. 12, n. 3, p. 577587, 1972. 
WEHNER, R. Polarized-Light Navigation by Insects insects have evolved for the purpose is remarkably sophisticated. Scientific American, v. 235, n. 1, p. 106-115, 1976.

WILSON, D. S.; SOBER, E. Reviving the superorganism. Journal of Theoretical Biology, v. 136, n. 3, p. 337-356, fev. 1989.

WILSON, E. O. Caste and division of labor in leaf-cutter ants (Hymenoptera: Formicidae: Atta) I. The Overall Pattern in A. sexdens. Behavioral Ecology and Sociobiology, v. 7, n. 2, p. 143-156, jul. 1980.

WILSON, E. O. CHEMICAL COMMUNICATION AMONG WORKERS OF THE FIRE ANT Solenopsis saevissima (Fr . Smith) 1. The organization of mass-foraging. 1962.

WILSON, E. O. Chemical communication among workers of the fire ant Solenopsis saevissima (Fr. Smith) 2. an information analysis of the odour trail. Animal Behaviour, v. 10, n. 1-2, p. 159-164, jan. 1962.

WILSON, E. O. Chemical communication among workers of the fire ant Solenopsis saevissima (Fr. Smith) 3. The experimental induction of social responses. Animal Behaviour, v. 10, n. 1-2, p. 159-164, 1962.

WILSON, E. O. The relation between caste ratios and division of labor in the ant genus Pheidole (Hymenoptera: Formicidae). Behavioral Ecology and Sociobiology, v. 16, n. 1, p. 89-98, nov. 1984.

WILSON, E. O.; HÖLLDOBLER, B. Eusociality: origin and consequences. Proceedings of the National Academy of Sciences of the United States of America, v. 102, n. 38, p. 13367 13371, 2005.

WILSON, Edward O. Sociobiology. Harvard University Press, 2000.

YAN, H. et al. An Engineered orco Mutation Produces Aberrant Social Behavior and Defective Neural Development in Ants. Cell, v. 170, p. 736-747, 2017.

YILMAZ, A. et al. Eye structure, activity rhythms, and visually-driven behavior are tuned to visual niche in ants. Frontiers in behavioral neuroscience, v. 8, n. June, p. 205, jan. 2014.

YOUNG, A. J. et al. Workforce Effects and the Evolution of Complex Sociality in Wild Damaraland Mole Rats. The American Naturalist, v. 186, n. 2, p. 302-311, 2015. 


\section{Material suplementar}

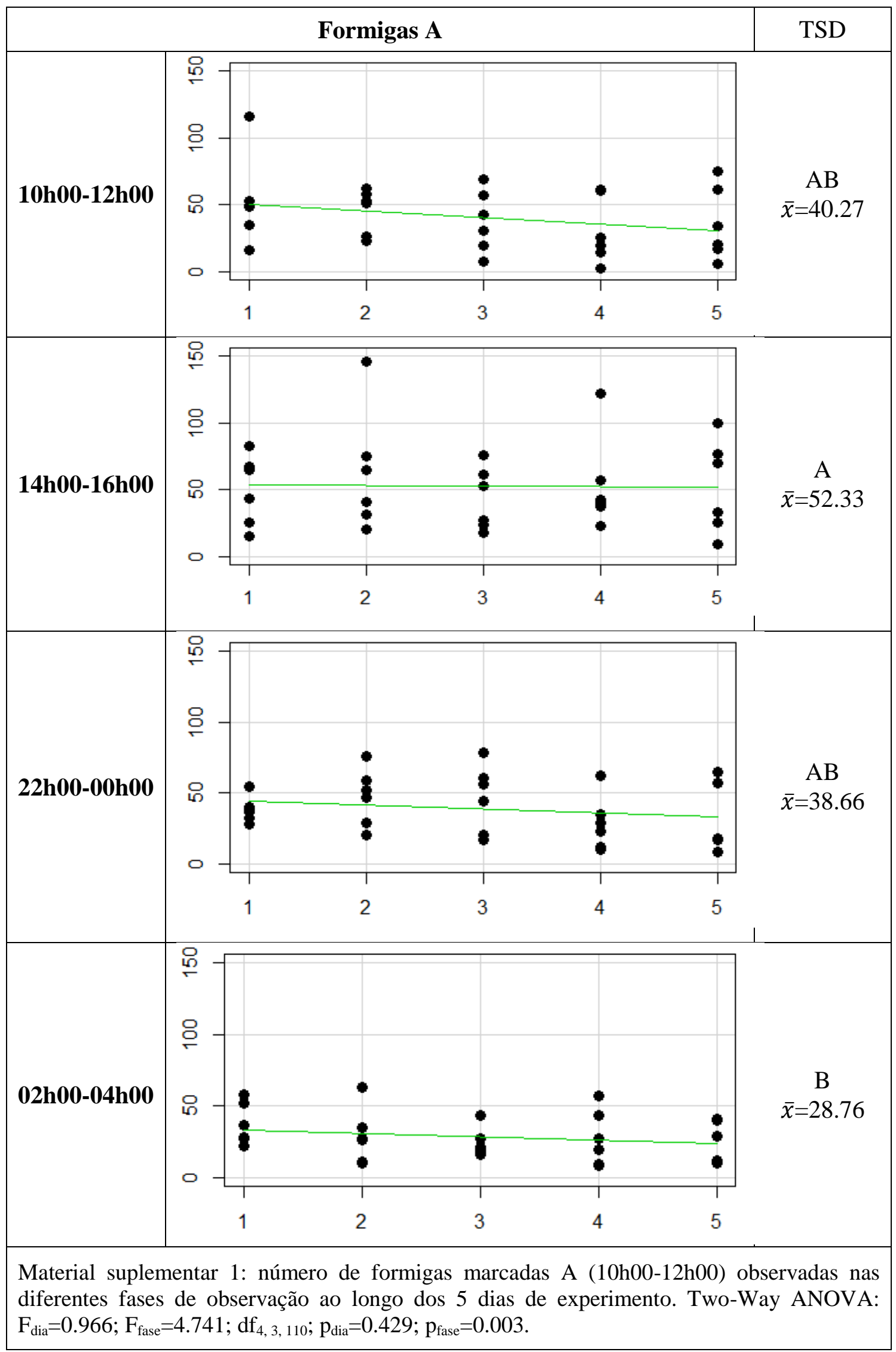




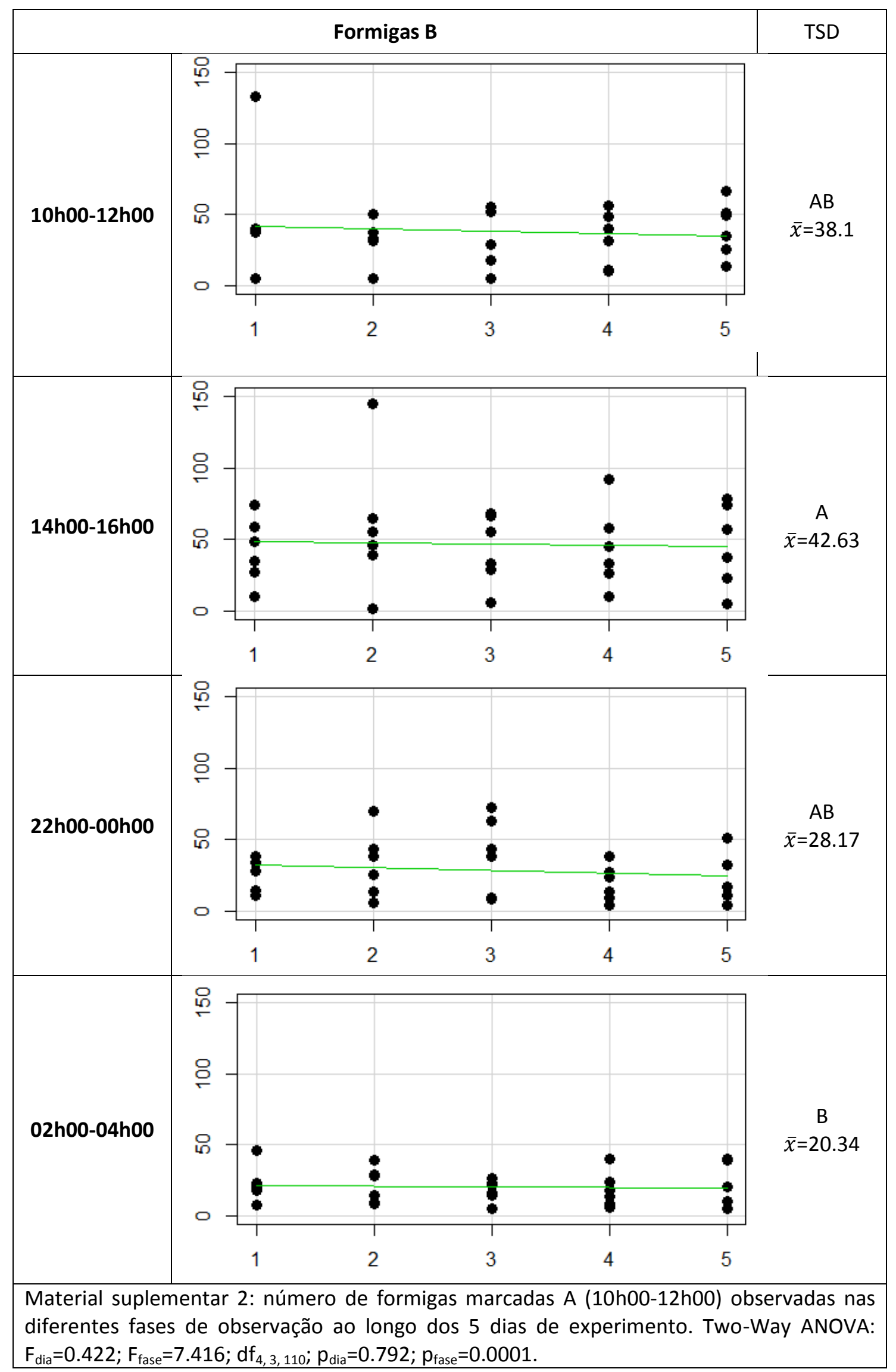




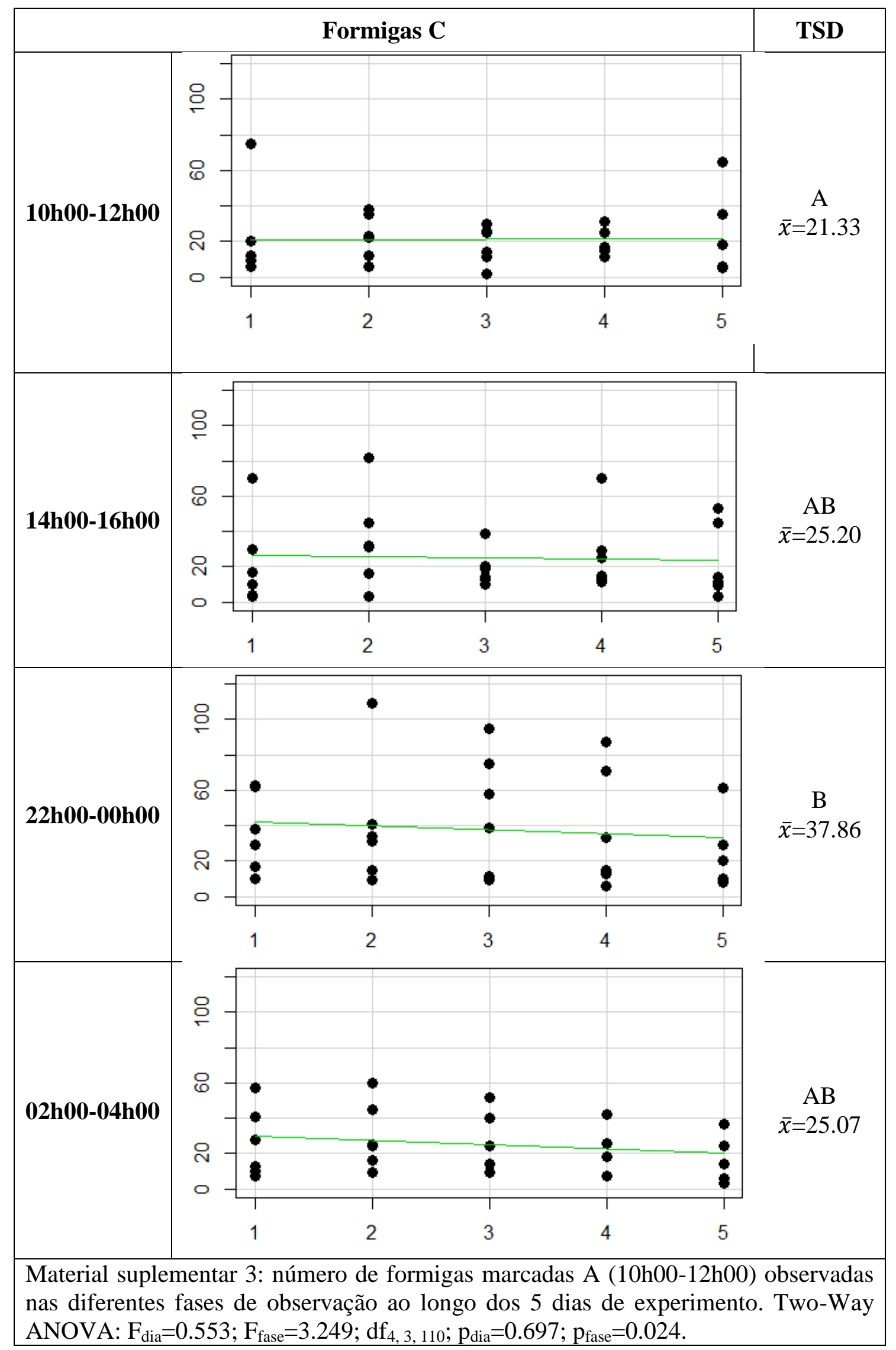




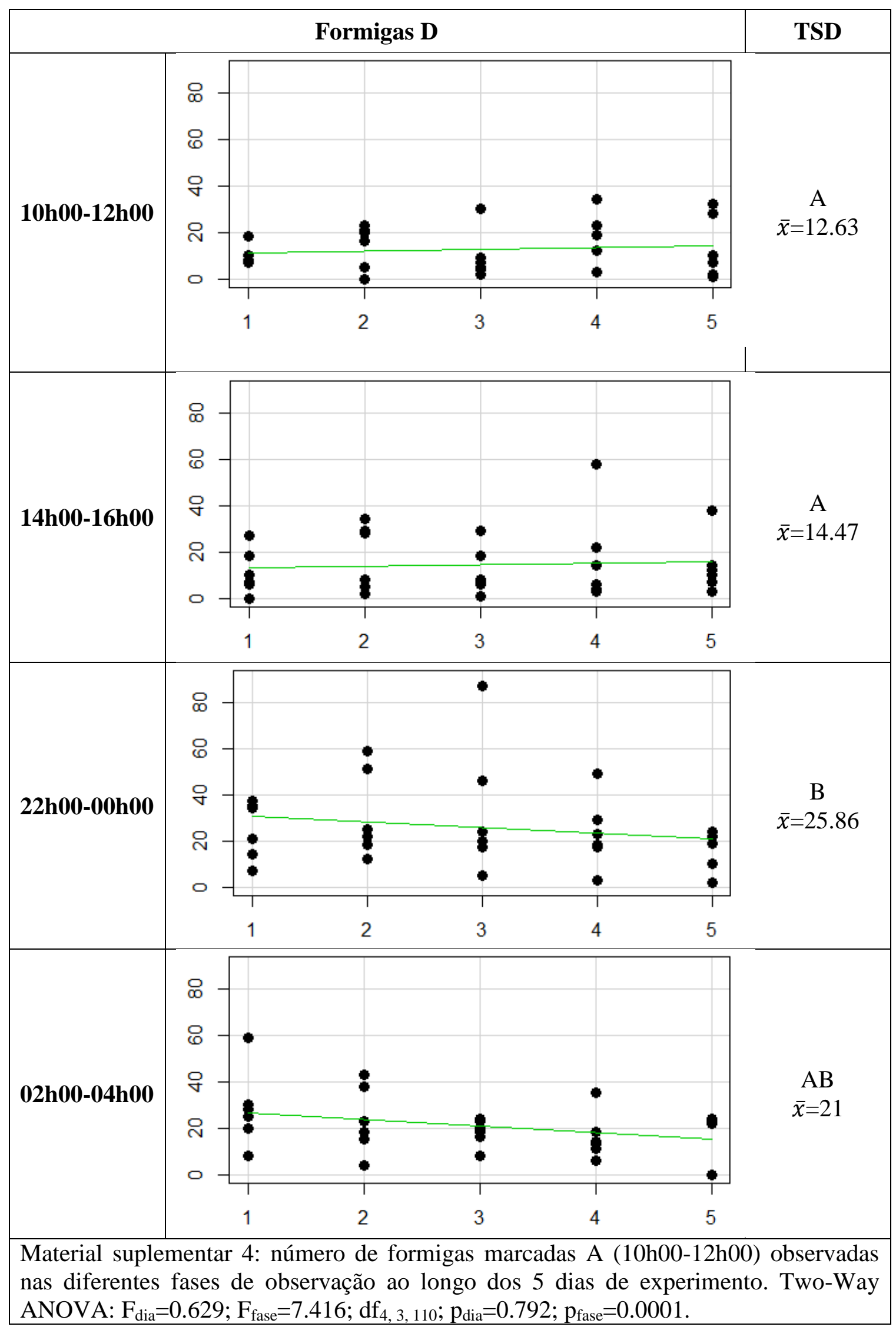




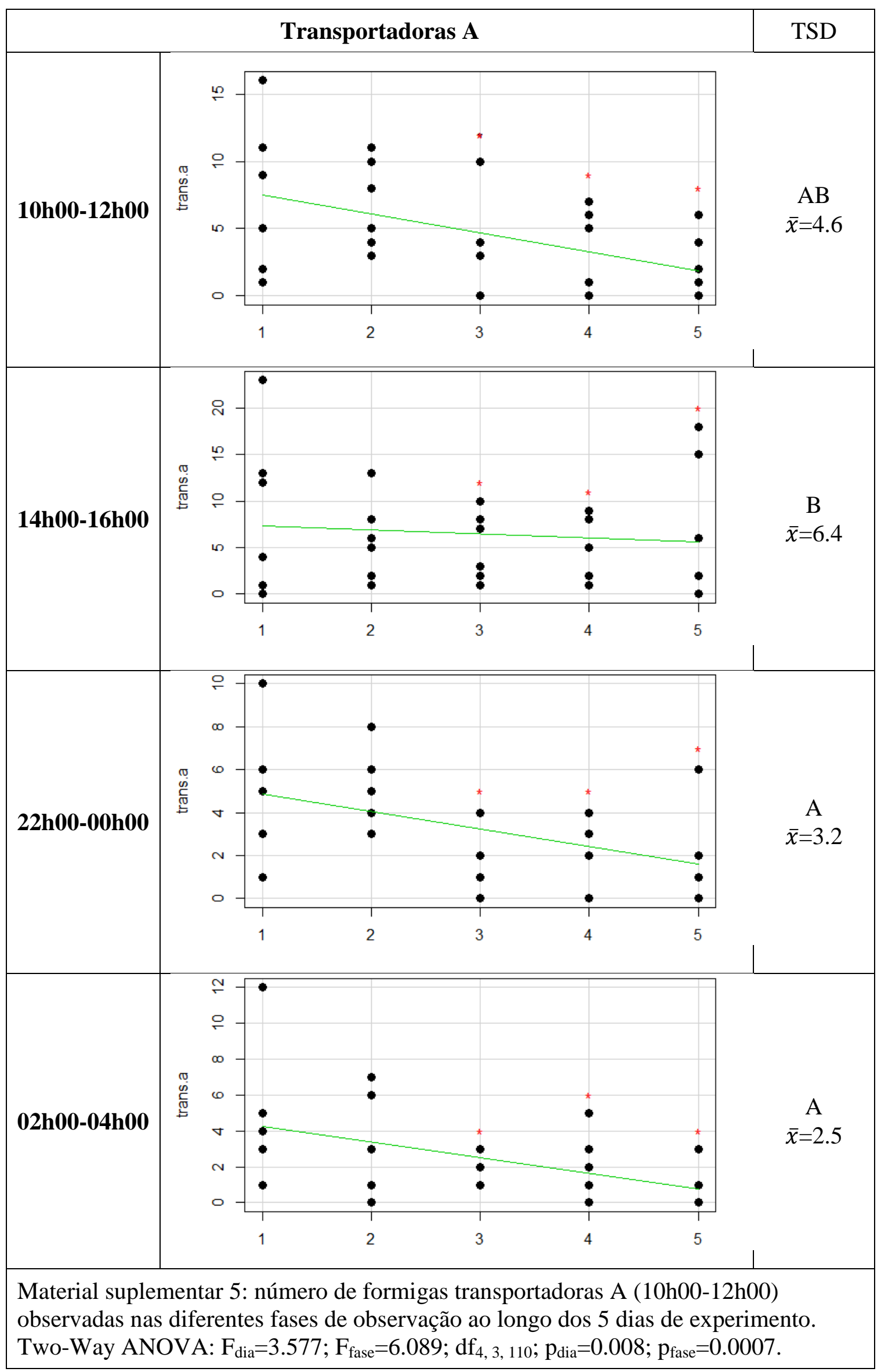




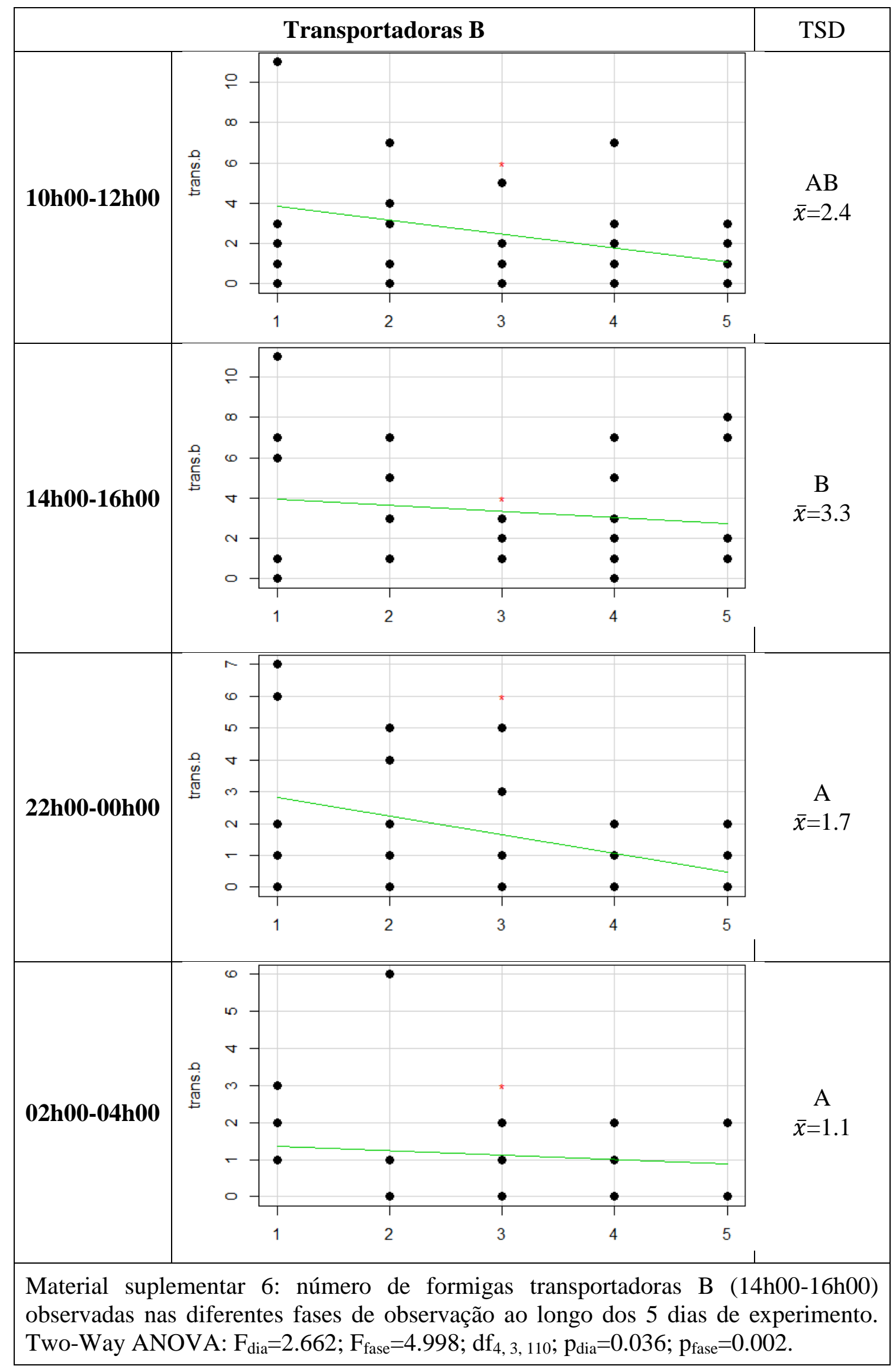




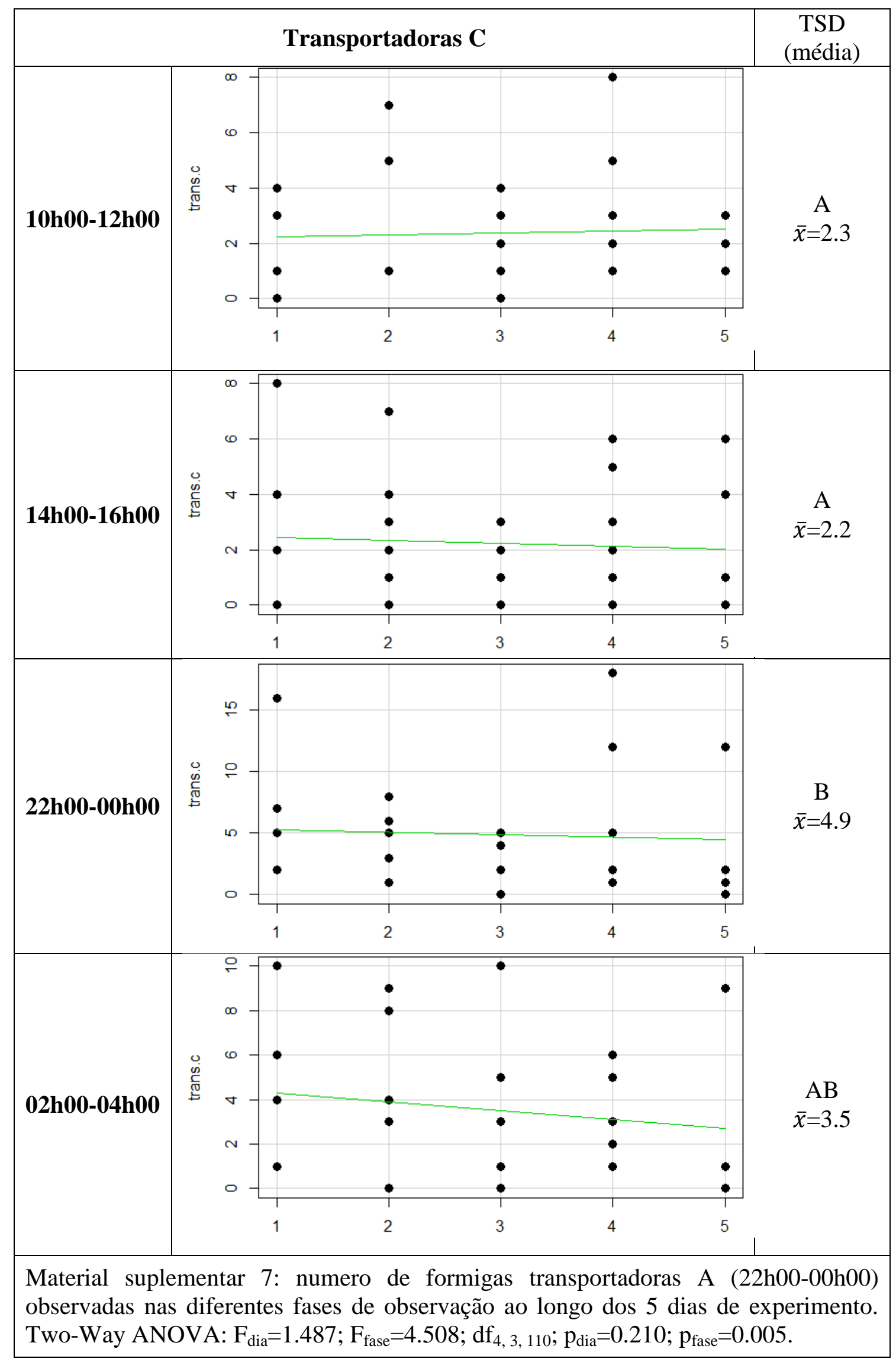




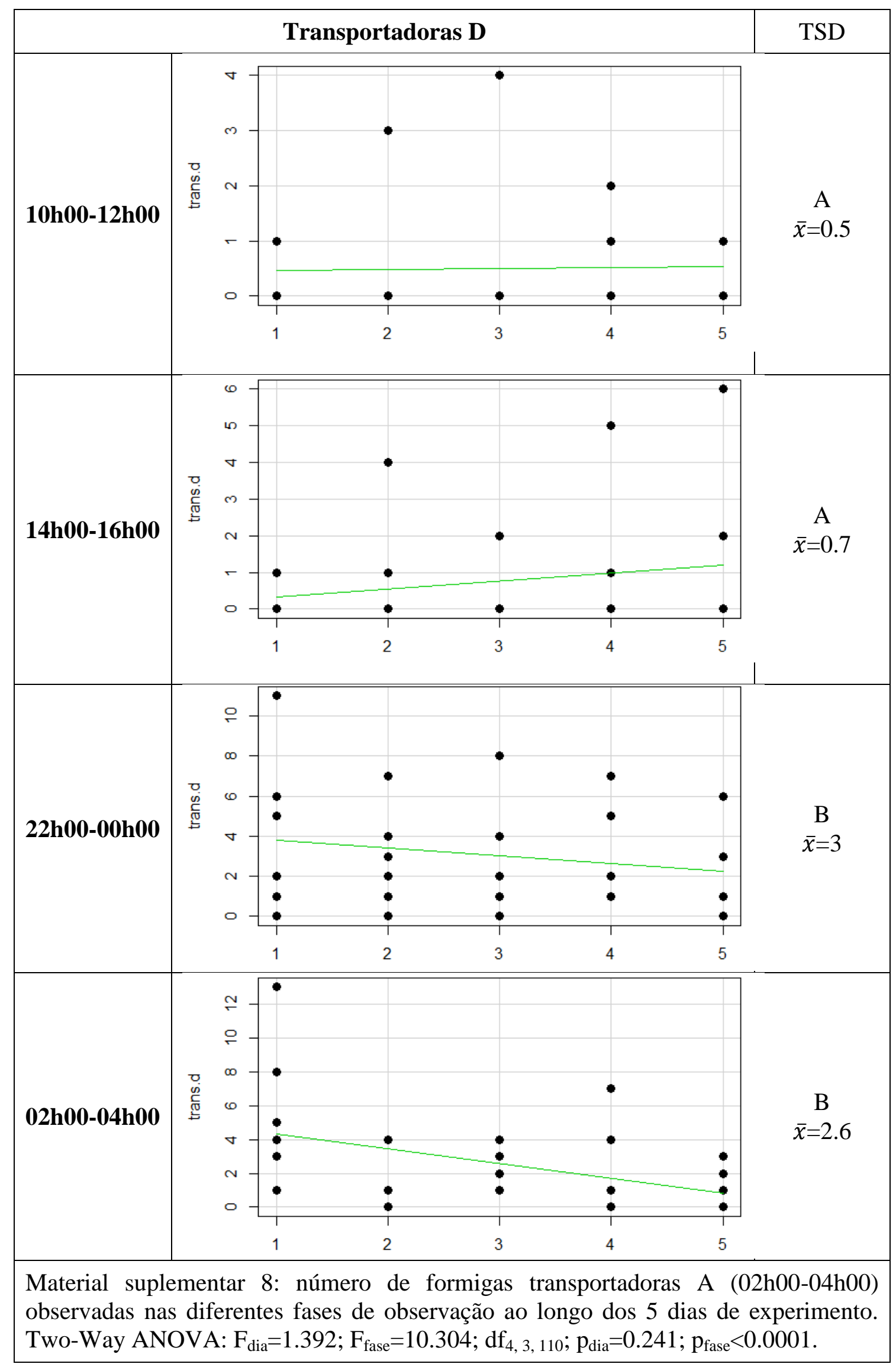


